\title{
MEMORIA DE LOS ANDES
}

El concepto de historia en Los pensamientos del indio que se educó dentro de las selvas colombianas de Manuel Quintín Lame

JUAN DAVID SANABRIA MONROY

CÓDIGO: 2138105

\author{
UNIVERSIDAD SANTO TOMÁS \\ FACULTAD DE FILOSOFÍA Y LETRAS \\ MAESTRIA EN FILOSOFIA LATINOAMERICANA \\ BOGOTÁ D.C. \\ 2016
}




\section{MEMORIA DE LOS ANDES}

El concepto de historia en Los pensamientos del indio que se educó dentro de las selvas colombianas de Manuel Quintín Lame.

JUAN DAVID SANABRIA MONROY

CÓDIGO: 2138105

TRABAJO DE TESIS PARA OPTAR AL TÍTULO DE

MAGÍSTER EN FILOSOFÍA LATINOAMERICANA

DIRECTOR

PROFESOR ALVARO ACEVEDO

UNIVERSIDAD SANTO TOMÁS

FACULTAD DE FILOSOFÍA Y LETRAS

MAESTRIA EN FILOSOFIA LATINOAMERICANA

BOGOTÁ D.C.

2016 
Nota de aceptación

\begin{tabular}{r} 
Jurado \\
Patricia Rubiano \\
\hline Juan Cepeda \\
\hline \\
Jurado \\
Álvaro Acevedo
\end{tabular}

Bogotá, D.C., abril de 2016 


\section{Dedicatoria}

Dedico este trabajo de investigación, en primer lugar a mi familia, mi Hijo Tomás, mi esposa Carmen, mis padres Lucy y Gerardo y mis hermanas Diana y Jessica, quienes con su apoyo diario son el motor para lograr todos los logros y toda la motivación de trabajo y creatividad.

Agradezco a mis docentes, particularmente al profesor Álvaro Acevedo que con su apoyo intelectual, hicieron posible la realización de este trabajo de investigación que lleno mis expectativas académicas, respecto a la aplicación de la Maestría en Filosofía Latinoamericana.

Brindo esta labor investigativa a toda la comunidad indígena colombiana, que se empeña en rescatar de la historia, y su cultura, para reconstruir una sociedad en paz a partir de la relación espiritual con su territorio, y les agradezco la enorme influencia que ha ejercido en mí todo su de lucha y resistencia, como ejemplos de dignidad y fortaleza. 
Resumen: En este trabajo de investigación se pretende hacer una hermenéutica de la obra de Manuel Quintín Lame, Los pensamientos del indio que se educó dentro de las selvas colombianas para conceptualizar la concepción de historia de este autor. Una vez analizada la estructura general se plantean tres caminos interpretativos para analizar el texto: el desarrollo de la filosofía de la historia que establece un marco sobre los cuestionamientos e implicaciones de la categoría de historia sobre la que se pretende indagar al pensamiento de Lame, las categorías del pensamiento andino que posibilitan y configuran las concepciones intelectuales del autor, y finalmente un análisis de la visión de la historia del líder indígena desde la propuesta foucaltiana de indagar por la "historia de los vencidos".

Palabras claves: Manuel Quintín Lame, historia, filosofía de la historia, pensamiento andino, movimiento indígena, historia de los vencidos.

Abstract: In this research work I am trying to develop a hermeneutics from Manuel Quintín Lame's work, The thoughts of the Indian who was educated inside the Colombian Jungles, for conceptualizing the conception of the history of this autor. After analyzing the overall structure of the text, they are establishing three interpretive paths to analyze text: the development of philosophy of history that establishes a framework for the questions and implications for the category of history to it delves inside the Lame's thought, the categories of the andian's thougth to enable and configure the intelectual conceptions in this autor, and finally an analysis about the visión of history to this indian leader from the proposal of Foucalt to inquire about the "history to the vanquished".

Key Words: Manuel Quintín Lame, history, philosophy o history, andian 's thought, indigenous movement, history of the vanquished. 


\section{Tabla de Contenido}

Pág.

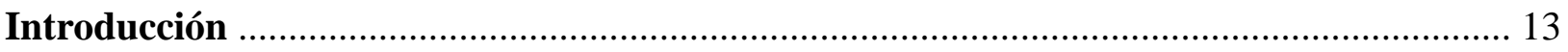

Capítulo 1. Manuel Quintín Lame................................................................17

1.1 Reseña biográfica sobre Manuel Quintín Lame..............................17

1.2 Estado del arte sobre Manuel Quintín Lame......................................... 20

1.3 Los pensamientos del indio que se educó en las selvas colombianas.............25

Capítulo 2. La pregunta filosófica por la historia.............................. 33

2.1 El concepto de historia y sus implicaciones metodológicas....................... 33

2.2 Sobre el desarrollo de la filosofía de la historia en el pensamiento occidental...39

2.2.1 Reflexión sobre la historia en el pensamiento griego............................. 39

2.2 2 Filosofía de la historia en el pensamiento judeo cristiano.......................43

2.2.3 Filosofía de la historia en la modernidad.......................................... 47

2.3 La historia de los vencidos como perspectiva de análisis................................53

Capítulo 3. Categorías centrales de la episteme andina.......................................63

3.1 La zona cultura quechua...........................................................64

3.2 La pacha como fundamento y sostén de la episteme andina......................72 
3.3 La visión andina de Dios y el cristianismo de Quintín Lame.

3.4. Generalidades del pensamiento nasa..............................91

Capítulo 4. Concepción de historia en Manuel Quintín Lame............................... 97

4.1 El relato histórico en Quintín Lame: Narración simbólica a partir de la

confluencia entre mito y hecho histórico en el pensamiento andino......

4.2.Temporalidad y desarrollo histórico en Quintín Lame, a partir de la

representación narrativa y estética del principio de la metamorfosis de la vida

( Pees Kupx) del pueblo Nasa

.107

4.3 La historia en el texto de Quintín Lame..........................115

4.4 Las historias de los vencidos en América Latina.............................122

4.4.1. El relato de Guamán Poma de Ayala como historia de los vencidos

4.5 La historia en Quintín Lame como historia de los vencidos .126

Conclusiones. 131

Anexos. 145

Bibliografía. 150 


\section{Lista de Gráficas}

Pág.

Gráfica 1. Metodología de Investigación...................................................62

Gráfica 2.Representación geométrica de la historia Nasa....................................................114 


\section{Lista de Mapas}

Pág.

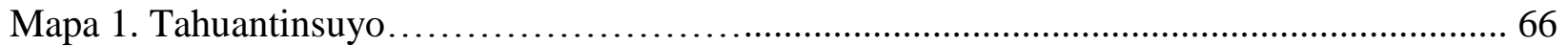

Mapa 2. Territorio de la comunidad Nasa............................................94 


\section{Lista de tablas}

Tabla 1. Cronología de Quintín Lame................................................................................ 19 


\section{Lista de fotos}

Pág.

Foto 1.Afiche conmemorativo, aniversario luctuoso Manuel Quintín Lame.....................14

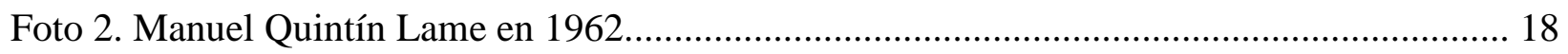

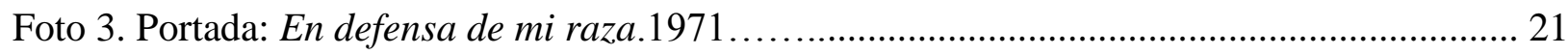

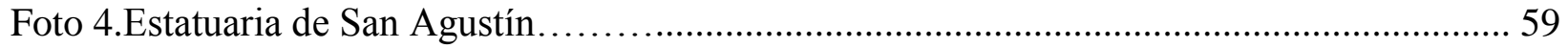

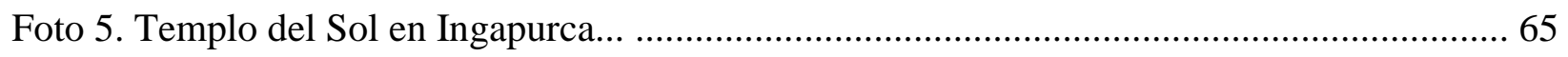

Foto 6.Mujer de la comunidad Los Pastos ..................................................................................69

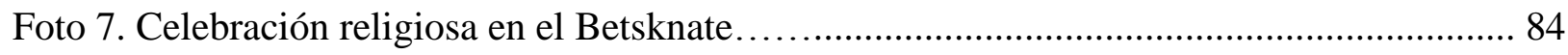

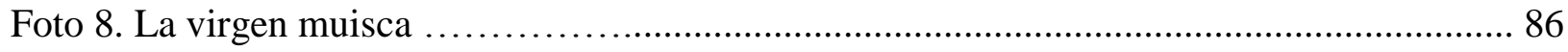

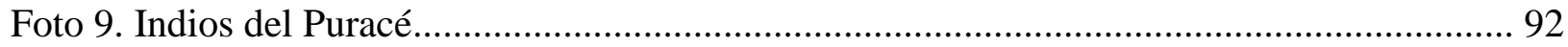

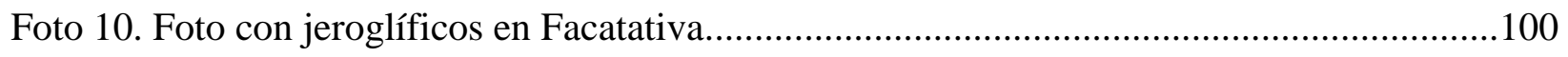

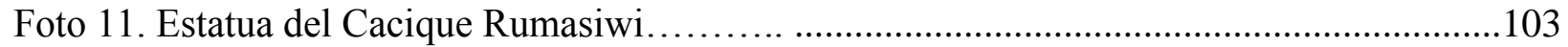




\section{Introducción}

Manuel Quintín Lame, es un personaje central del siglo XX en Colombia, en tanto su pensamiento lo erigió como ideólogo de las luchas y formas organizativas del movimiento indígena de nuestro país, promoviendo un sentido de comunidad y territorio en áreas donde el colonialismo había erradicado formas de trabajo, organización y propiedad ancestral de la tierra. La presente investigación se centrará en su obra Pensamientos del indio que se educó en las selvas colombianas (1971), indagando cómo en el texto existe una concepción de la historia, que recoge elementos del pensamiento andino con fines políticos e ideológicos.

Este trabajo de investigación pretende conceptualizar la visión de historia del más influyente líder de la comunidad Nasa, cuya actividad política e intelectual se llevó a cabo en las primeras cuatro décadas del siglo XX, a través de un trabajo hermenéutico propuesto en tres ejes de trabajo.

En primer lugar, se plantea una revisión de los más insignes representantes de la filosofía de la historia, como punto de partida para asumir la historia en tanto problema filosófico, y a partir de allí, establecer las coordenadas sobre las que es necesario cuestionar al texto de Lame en búsqueda de su pensamiento sobre la historia, partiendo de la asunción de la pregunta como herramienta de interpretación textual. En segundo lugar, se plantea una contextualización cultural de la obra de Manuel Quintín Lame en el marco del pensamiento andino, lo que implica la necesidad de revisar categorías fundamentales de esta forma geo culturalmente ubicada de asumir la realidad, para poder establecer los elementos que enmarcan, configuran y posibilitan el lugar de enunciación de Lame y su pensamiento mismo. En tercer lugar, se plantea interpretar la concepción de Manuel Quintín Lame en el marco de lo que hemos denominado como historia de los vencidos, es decir, entender la relación y la novedad que hace Lame a un corpus de formas 
de entender la historia surgido bajo la sombra del colonialismo europeo y su accionar opresivo sobre los pueblos indígenas, y valorar dicho pensamiento como un espacio de resistencia y reelaboración de la sabiduría ancestral para dar respuesta a los problemas inmediatos de los pueblos aborígenes. Lo anterior adquiere una fortaleza inusitada en el caso concreto del autor a trabajar, en tanto el movimiento indígena colombiano lo considera como su gran ideólogo y configurador.

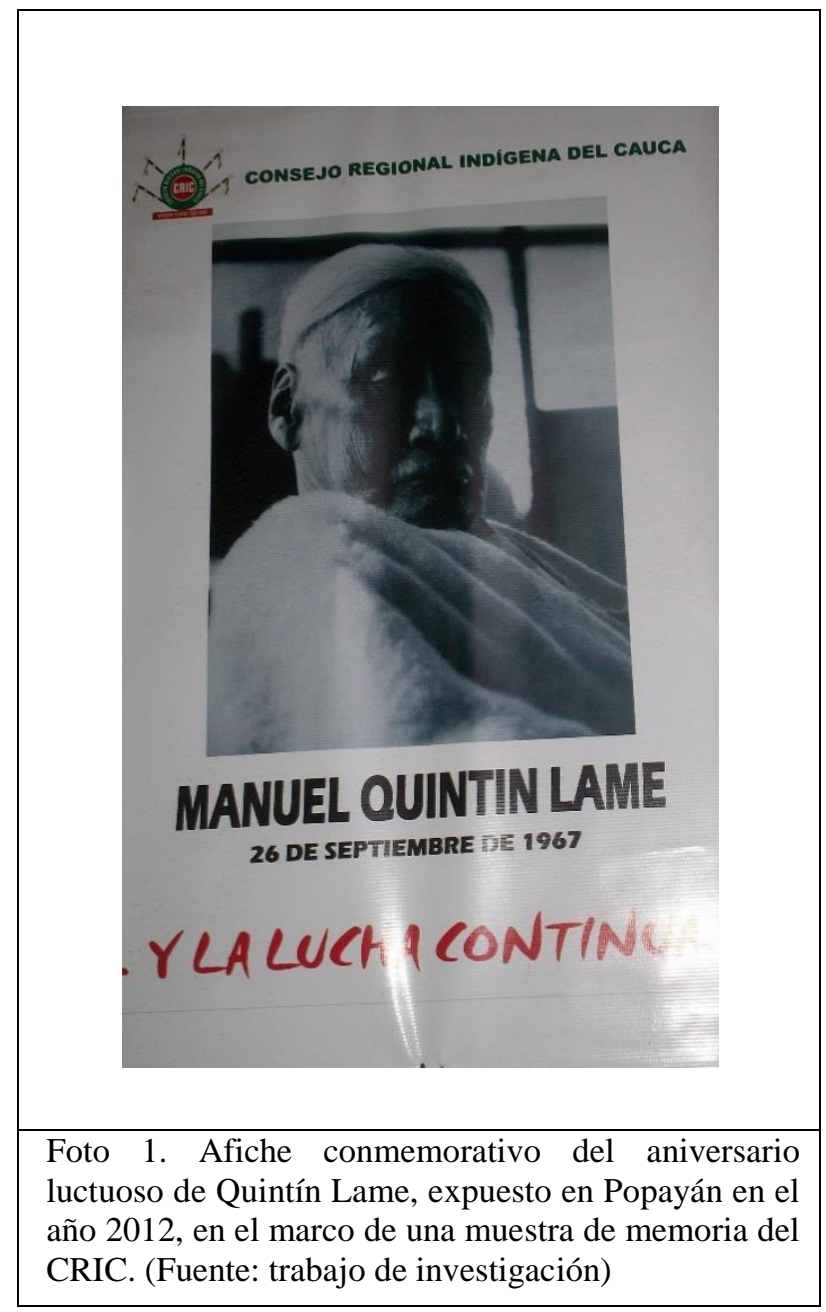

Es importante rastrear y analizar la visión de Manuel Quintín Lame sobre la historia, por cuanto implica no solo la rememoración, sino también una herramienta interpretativa sobre 
hechos significativos de la memoria de América Latina y de sus pueblos ancestrales, que van quedando en el olvido, pero que a partir de la reconstrucción histórica en voz de sus propios actores permite la reflexión crítica de los acontecimientos relevantes y así se puedan recuperar los aprendizajes y desarrollos del pensamiento andino como, que se dieron desde el asentamiento y desarrollo de su territorio en marco de una relación de índole espiritual con el mismo, y el posterior proceso de reivindicación, defensa y resistencia que se da a partir de la imposición del colonialismo español.

Ahora bien, la Academia colombiana ha dado cuenta de la obra de Lame, desde diversas disciplinas como la historia, las ciencias políticas o la antropología; pero las investigaciones filosóficas en nuestro país tienen un saldo pendiente con este pensador indígena, que , en parte, este trabajo busca empezar a subsanar. La elección de este autor, corresponde a una aspiración filosófica, de aportar desde el contexto colombiano, a la propuesta de Filosofía Andina, que se ha trabajado fundamentalmente en el Perú, desde autores como Juvenal Pacheco Farfán (1994), Víctor Mazza Huaycucho(1994), María Luisa Rivara de Tuesta(2000), o Mario Mejía Huaman. También es importante en este sentido, señalar al autor alemán Joseph Estermann (1998), quien trabaja la filosofía andina desde un enfoque intercultural. En este sentido, se busca desde este trabajo investigar el pensamiento de Lame, para hacer un aporte al objetivo que delimitan los autores anteriormente citados, una contribución creativa al desarrollo de la Filosofía, haciendo una reflexión desde los conceptos propios del pensamiento y las lenguas andinas.

Por su parte, la elección de la filosofía de la historia como un eje de reflexión, se hace recogiendo las críticas que Foucault (1968) ha señalado sobre el mismo. En un marco epistemológico en el que la verdad del conocimiento es sostenida por las representaciones de un sujeto único, resulta evidente que las "pequeñas historias" carecen de significación. Las 
reivindicaciones de sexo, raza, edad y condición social, son aprisionadas por la modernidad en un pensamiento homogeneizante, en donde deberá buscarse el sentido mayor de la historia tomando como eje de la interpretación, el pensamiento ilustrado. En ese sentido, es una tarea de la filosofía latinoamericana realizar una construcción propia de la filosofía de la historia, que partiendo de nuestros autores, y nuestras categorías de pensamiento permitan generar una lectura de la historia partiendo de América Latina misma.

En este orden de ideas, se busca hacer una contribución a la construcción de una filosofía de la historia que permita racionalizar el discurso simbólico propio del pensamiento andino, en este caso concreto del texto de Lame, para rastrear en él una concepción de la historia desde la que se pueda aportar críticamente a la reflexión filosófica en nuestro continente. 


\section{Capítulo 1}

\section{Manuel Quintín Lame}

\subsection{Reseña biográfica sobre Manuel Quintín Lame}

Manuel Quintín Lame Chantre (1883 -1967) es la figura más importante de las movilizaciones indígenas colombianas del siglo $\mathrm{XX}$, y pionero del desarrollo de un pensamiento de liberación indígena en nuestro país. A manera de esbozo biográfico, podemos decir que Quintín Lame fue un indígena nasa nacido en 1880 en los alrededores de Popayán, en medio de una situación social marcada por el terraje, una relación de carácter servil, en la cual un indígena debía pagar en trabajo gratuito dentro de la hacienda el derecho a vivir y usufructuar una pequeña parcela, a pesar de que muchas de las tierras en las que se presentaba este fenómeno, hacían parte de territorios ancestrales de los que habían sido despojados los indígenas.( Castrillón,1973,18)

Con el estallido de la guerra de los Mil Días en 1899, Quintín Lame fue alistado a la fuerza en las fuerzas del General Carlos Albán, quien lo convirtió en su ordenanza, y lo llevó con la tropa a Panamá, donde conoció la lucha guerrillera de Victoriano Lorenzo, un indígena guaimí, cuyo accionar fue clave para la victoria de los ejércitos liberales sobre los conservadores en el istmo. A su regreso al Cauca, Lame se dedicó de forma autodidacta al estudio legal de los títulos de propiedad de los resguardos; elaborando cientos de memoriales, demandas y solicitudes, para lograr la devolución de las tierras de los indios. Desarrolla entonces un activismo político e intelectual orientado en primer momento a terminar con el terraje y, posteriormente, a constituir un movimiento de liberación indígena que luchara por la recuperación del territorio y de las formas ancestrales de administrarlo. Castrillón $(1973,46)$ señala que en medio de esta lucha, Quintín Lame comienza a reivindicar la figura 
de Juan Tama de la Estrella, cacique nasa del período colonial de enorme influencia espiritual y quien logró que la corona española emitiera un título de propiedad sobre los resguardos del Cauca a favor de los indígenas. A partir de su actividad política expande su zona de influencia de su región de origen a los departamentos de Nariño, Putumayo, Valle del Cauca, Huila y Tolima. Esa experiencia sería posteriormente la base ideológica y organizativa del CRIC (Consejo Regional Indígena del Cauca).

Alrededor de 1915 comienza lo que se conocería como "La Quintiniada” una estrategia de confrontación directa que buscaba la recuperación de tierras por medio de la toma de haciendas, llegando a incluso a tomar pueblos enteros como Inzá y Belalcázar, en la zona de Tierradentro. Debido a estas acciones fue encarcelado en Popayán, motivo por el que tuvo que concentrar todos sus esfuerzos intelectuales en preparar su causa legal, pues decidió usar sus conocimientos legales para asumir su propia defensa, con la que logró salir libre. Una vez en libertad, se dedicó a consolidar organizativamente su movimiento, trabajo que fue periódicamente interrumpido por sucesivas estancias en la cárcel. A partir de este momento, se dio una radicalización tanto del movimiento de Lame como de la represión estatal en su contra, generando que principalmente en el Cauca y Nariño el conflicto social indígena escalara a una ola de violencia anti estatal y anti terrateniente, por el que es encarcelado durante cuatro años a partir 1917, período de amplia actividad intelectual en su presidio. Al recobrar su libertad en 1921, y ante la ausencia de condiciones de seguridad en el departamento del Cauca para continuar su activismo, se radica en el Tolima, desde donde intenta reorganizar su movimiento mediante la fundación del "Consejo supremo de Indios". En este período Lame concederá particular importancia al tema de la educación propia, 
interés materializado en proyectos como la escuela de San José de Indias en Ortega. (Espinoza, 2009,25)

En esta nueva etapa de su lucha, Quintín Lame vuelve a su forma de pensar y actuar del primer período del Cauca a través de formas legales de lucha. Durante esta lucha consigue la reconstitución del cabildo de Ortega y Chaparral y el reconocimiento del Resguardo de Ortega Chaparral, pero los terratenientes continúan manteniendo sus haciendas en las tierras de resguardo, contando con el apoyo de las autoridades departamentales y municipales. Y amplía su acción a las parcialidades del Huila, en donde emplea la estrategia de mingas que tanto éxito le había dado en el Cauca. Hasta que un choque armado con la policía de Neiva, en el cual resultaron 3 indígenas muertos y numerosos heridos, lo obliga a refugiarse otra vez en el Tolima.(Espinoza,2009,30)

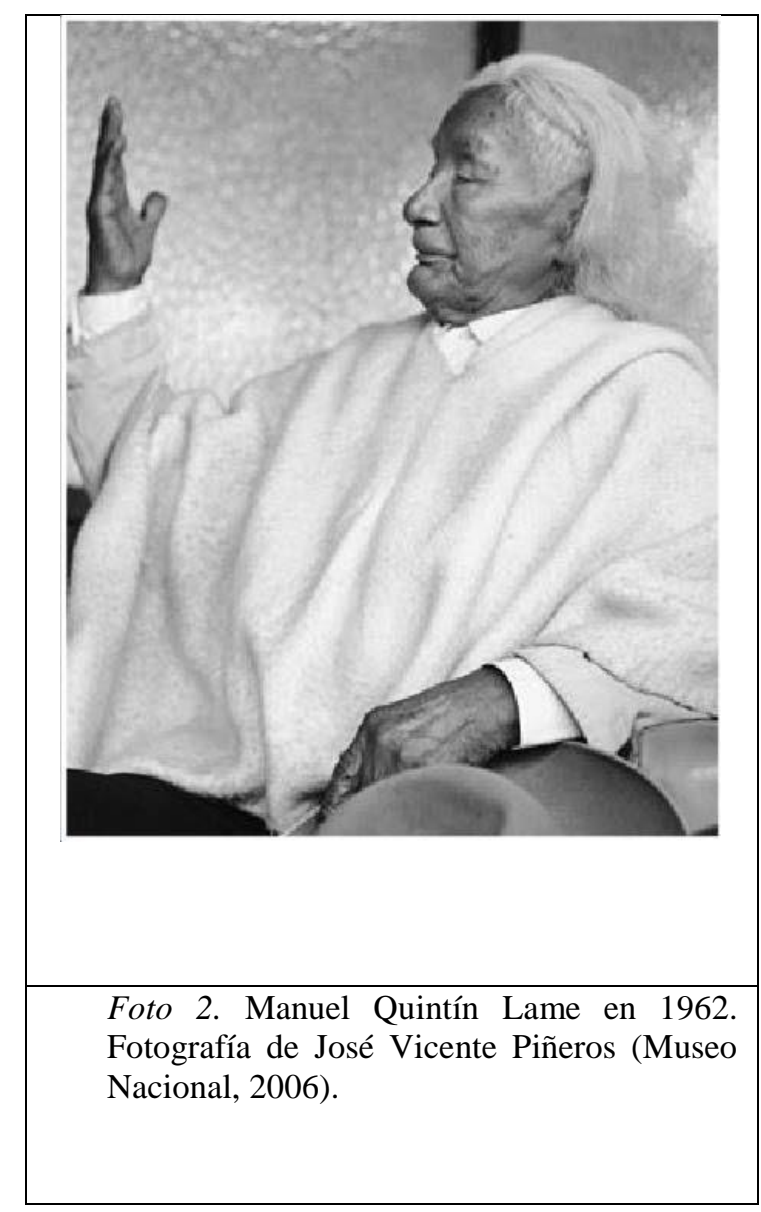


Allí, en 1931, los terratenientes organizan un asalto armado en su contra, tomándose la población de San José de Indias (ubicada en el municipio de Ortega), dando como resultado 17 indígenas muertos, 37 heridos y el incendio de la población. Lame huye y es perseguido por toda la región; capturado ese mismo año, permanece en la cárcel durante dos años. Al salir, se dedica por completo a la lucha legal, enviando memoriales, dictando conferencias, entrevistándose con las autoridades, incluso llega a ser elegido gobernador del cabildo de Ortega. Esta es la época en que comienza a dictar su libro. (Castrillón, 1973, 159).

Tabla 1. Cronología de Quintín Lame

\begin{tabular}{|c|c|}
\hline 1912 & $\begin{array}{l}\text { Inicia la redacción de memoriales reclamando la propiedad de la tierra para los } \\
\text { indígenas del Cauca. }\end{array}$ \\
\hline 1914 & Inicio de "la Quintiada", campaña de toma y recuperación de tierras. \\
\hline 1915 & $\begin{array}{l}\text { Toma de Inzá (Cauca). } \\
\text { Es detenido en Caloto (Caloto) acusado de robo y lesiones personales. }\end{array}$ \\
\hline 1916 & Toma de Belalcázar (Cauca). \\
\hline $\begin{array}{l}1917- \\
1921\end{array}$ & Detenido por rebelión y asonada. \\
\hline 1922 & $\begin{array}{l}\text { Se traslada al sur del Tolima. Inicia el proceso de lucha por la restitución de los } \\
\text { resguardos indígenas de Natagaima y Ortega. }\end{array}$ \\
\hline 1924 & Inicio del proceso educativo de San José de Indias. \\
\hline 1931 & $\begin{array}{l}\text { Ataque armado contra San José de Indias e incendio de la población. } \\
\text { Nuevamente encarcelado. }\end{array}$ \\
\hline 1933 & Es elegido gobernador del Resguardo Indígena de Ortega. \\
\hline 1939 & $\begin{array}{l}\text { Redacción del texto Los pensamientos del indio que se educó en las Selvas } \\
\text { Colombianas. }\end{array}$ \\
\hline
\end{tabular}

Fuente: Trabajo de investigación.

El texto de Manuel Quintín Lame se terminó de escribir en 1939; sin embargo, su autor no "escribe" propiamente el libro, sino que lo dicta a su secretario Florentino Moreno. Este hecho es de mucha importancia, pues ya desde su origen la escritura está supeditada a una construcción oral, lo cual se evidencia en los continuos y muchas veces innecesarios etcéteras 
al final de las frases, en la fractura de la linealidad del discurso, que no introduce o desarrolla un argumento, sino que, más bien, salta, como en una conversación, de un tema a otro; así mismo, en las continuas repeticiones, o los errores gramaticales, como la eventual falta de comas de algunos fragmentos del texto. Siguiendo el recorrido del libro de Lame, se sabe que inmediatamente después del año 1939 se difundió entre las comunidades indígenas y campesinas de manera oral (principalmente, aunque no exclusivamente, en los departamentos del Huila, Tolima y Cauca) y en un contexto de particular agitación política común a otros países latinoamericanos: el problema de la tenencia de la tierra. (Castrillón, 1973, 161).

\subsection{Estado del arte sobre Quintín Lame}

A pesar que el grueso de la producción textual de Manuel Quintín Lame se produjo entre las décadas de 1920 y 1930, la reflexión académica sobre la misma no iniciará hasta la década pensamiento de Manuel Quintín Lame hasta la década de 1970, cuando el profesor Gonzalo Castillo Cárdenas descubrió entre los documentos de los líderes de los cabildos indígenas del Tolima el manuscrito autoría de Quintín Lame, titulado, Los pensamientos del indio que se educó en las selvas colombianas (Lame,1971), que fue publicado en una edición autofinanciada por los colaboradores del investigador, en una antología llamada En defensa de mi raza. El impacto de la publicación del manuscrito, junto al texto breve La bola que rodó en el desierto, es que fue posible empezar a estudiar la obra del intelectual indígena.

A partir de entonces, el primer eje de estudio sobre Lame fue su interpretación como ideólogo figura inspiradora de las luchas y formas organizativas de los indígenas del suroccidente colombiano tales como el Consejo Regional Indígena del Cauca, el Concejo Regional indígena del Tolima, el movimiento armado Quintín Lame, o el movimiento Nietos de Quintín Lame (Velandia y Buitrago 1994;: Espinoza 2009). Otra corriente de estudio fue la que analizó el accionar político del líder nativo, principalmente desde una tradición historiográfica agrarista de influencia marxista y liberal. Las luchas indígenas y campesinas por la tierra fueron 
aquí entendidas como resultado de un patrón estructural de lucha producido por la modernización capitalista del sector agropecuario, el problema del latifundio, y el proceso de proletarización del campesinado (Fajardo 1981; Espinoza 2009). Varios estudios hicieron análisis de carácter político estratégico, en los que señalaron las limitaciones de la agenda de Lame, centrada en una concepción indígena "anclada en el pasado" con dificultades para establecer un frente unido de clase con otros sectores populares (Medina 1986, Gilhodes 1989; Espinoza 2009). Otros análisis hicieron énfasis en el caudillismo ejercido por Lame sobre el movimiento indígena, pues consideraban que ante la ola represiva estatal que se desató frente a la propuesta política de Lame, y la posterior desmembración del movimiento indígena que este promulgaba, se evidenció su falta de capacidad política para organizar un movimiento político de masas que no estuviera atado a su persona (Bonilla, 1979).

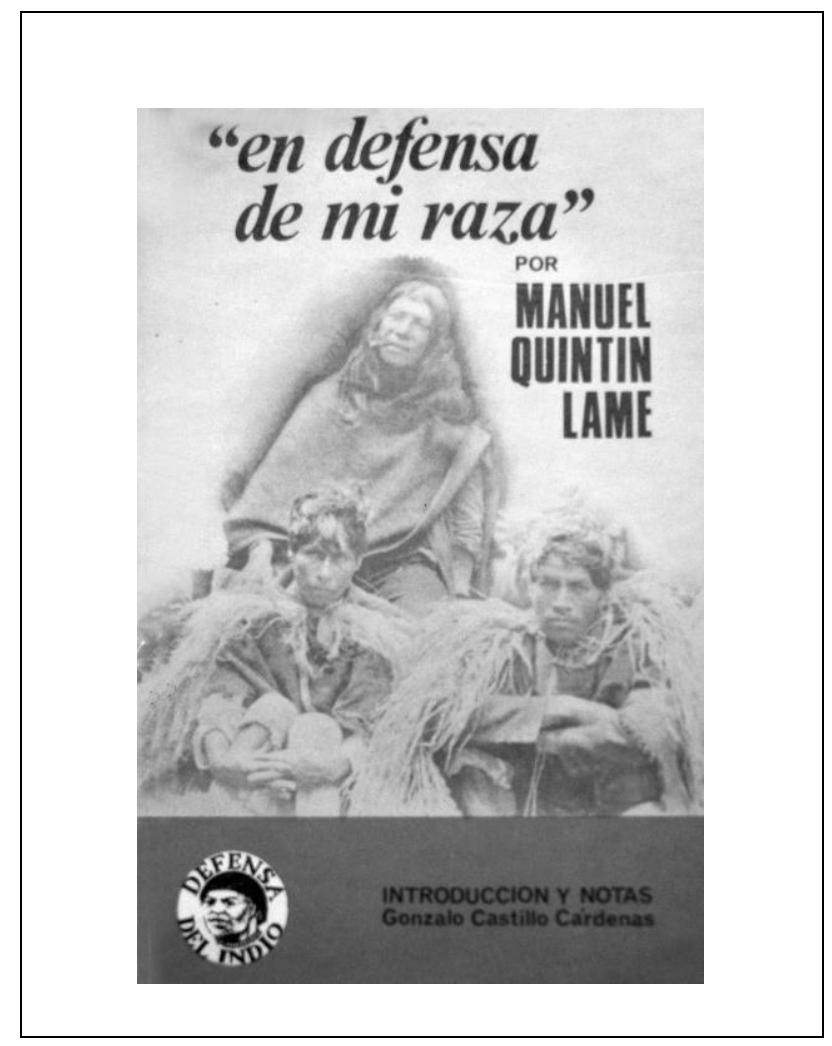


Foto 3. Portada original del libro En defensa de mi raza, donde se publicó por primera vez el texto Los pensamientos del indio que se educó en las selvas colombianas. (Lame, 1971)

Estos enfoques se centraron en desvirtuar el carácter revolucionario del líder indígena, debido a su religiosidad y a su proceso de "aculturación" en el que estaría influenciado por algunas ideas decimonónicas y republicanas, alejadas de un pensamiento puramente indígena ( Theodosiadis, 2000). Lo anterior es retomado por Renán Vega Cantor (2002) quien avanza en la lectura política de Lame, planteando que este reinventó las instituciones del resguardo y el cabildo, promoviendo un sentido de comunidad y territorio en áreas donde la represión estatal y terrateniente había destruido formas de trabajo, organización y propiedad de la tierra. Para Vega Cantor (2002) el problema del proyecto político de Lame, fue su marcado "legalismo" y sus concepciones caudillistas del liderazgo, lo que le impidió articularse a otras formas de resistencia existentes en el país y habría socavado las posibilidades de articularse a un movimiento de liberación nacional mucho más amplio. Finalmente, planteó que la condición de "aculturado" de Lame le habría imposibilitado comprender la tradición indígena propia y “el carácter destructivo de las ideologías nacionalistas".

Desde la década de los setenta, dentro del campo de lo que podríamos llamar la historiografía dedicada a los nasas, surgieron estudios centrados en la dimensión histórica del pensamiento de Lame y su relación con la memoria cultural de ese grupo. Esos estudios examinaron el proceso de transformación del sistema tradicional de autoridad y poder desde la conquista española hasta el surgimiento del Estado nacional moderno (Sevilla 1976; Tello, 1982; Findji y Rojas, 1985; López del Rey, 1992; Espinoza 2009). Findji y Rojas propusieron una 
tipología que iba desde el "cacique colonial" hasta el "cacique republicano". De acuerdo con estos autores, el cacique republicano debió adaptarse a los cambios derivados del nuevo ordenamiento político y jurídico del Estado - Nación y las luchas intestinas por el poder entre liberales y conservadores. Dentro de esta perspectiva, Lame fue llamado "cacique sin cacicazgo" (debido a que no ocupo un rol como autoridad indígena tradicional) y "caudillo", es decir, líder dotado de una personalidad carismática, que asumiría el liderazgo de una propuesta populista de reivindicaciones políticas (Tello 1987; Sánchez 1996, Triana 1993; Velandia y Buitrago 1994). En este sentido, en su estudio, sobre la formación del cacicazgo de los nasas y el surgimiento de una narrativa fundacional que los define como grupo étnico moderno, Joanne Rappaport (1998) planteó que Lame se reapropió de la simbología del cacique nasa para crear una unidad política donde no la había.

El estudio de Gonzalo Castillo (1987) abre un nuevo espectro para la interpretación de la obra de Quintín Lame. Castillo se aproxima al pensamiento religioso del líder, que hasta entonces había sido relegado a una condición peyorativa, y es definido en este texto como una "teología profética de liberación", orientado a la justicia como un genuino criterio de fe y enlazado a una visión mesiánica de la historia que tuvo un gran poder libertario entre los indígenas. El estudio de Fernando Romero ( 2006) mostró una faceta poco conocida de Lame como pensador popular, que ayudó a forjar una tradición pedagógica entre los indígenas, basada en una apropiación intercultural del conocimiento y una estrategia activa de educación.

El segundo trabajo de Rappaport, (2004) propuso reflexionar sobre las consecuencias de la publicación del tratado de Lame y su rol en los procesos de movilización indígena contemporáneos. Rappaport, se dio a la tarea de examinar las varias lecturas y formas de rescritura del tratado de Lame en asambleas políticas, talleres educativos y cartillas pedagógicas 
de organizaciones indígenas. De acuerdo con ella, la noción de interculturalidad, que emerge de las prácticas de los activistas indígenas y todos aquellos comprometidos con el desarrollo de programas indígenas de educación bilingüe está ligada a un proceso de reinterpretación selectiva de ideas y de construcción de un diálogo pluralista, en el que la comunicación interétnica desempeña un rol central.

El trabajo de Mónica Espinoza Arango en El indio lobo. Manuel Quintín Lame en la Colombia moderna (2003) ofrece interpretaciones del pensamiento de Manuel Quintín Lame, estructuradas en tres ejes temáticos: 1) la humanidad; 2) la historia; y 3) la escritura y la mímica. Se analiza a Lame como un "otro inapropiado e inapropiable", explorando formas de interpretación feministas del "sujeto", preocupaciones de la poscolonialidad en torno a la alterización y construcción del Otro dentro de taxonomías raciales y tecnologías de poder de la colonialidad /modernidad y, finalmente, el interés de la teoría del discurso por la construcción de sentidos y significados dentro de interacciones culturales inmersas en relaciones de dominaciónresistencia y regímenes disciplinarios de poder y saber. Se explora la "transculturalidad" de dicho pensamiento, su carácter "descolonizador", sus dinámicas de auto-representación y traducción, su ambivalencia, no-originalidad y reinvención cultural. De igual forma. La misma autora en $L a$ civilización montés: La visión india y el trasegar de Manuel Quintín Lame en Colombia (2009) realiza un trabajo antropológico alrededor del autor centrado en examinar la experiencia de Lame y sus seguidores a partir del análisis de sus narraciones indígenas, la puesta en escena de su visión política y el seguimiento de unas rutas de memoria cultural.

Sobresale en este sentido, el hecho que en la pesquisa realizada para la presente investigación, no se han encontrado referencias a trabajos desde la filosofía, motivo por el cual es lícito afirmar que el objeto de estudio del presente texto corresponde a un campo novedoso 
para la filosofía latinoamericana, en tanto se ocupa de un autor relevante para el pensamiento de nuestro continente, cuyo pensamiento no ha sido objeto de la reflexión filosófica.

\subsection{Los pensamientos del indio que se educó en las selvas colombianas}

Una de las principales características de la obra de Lame es su capacidad para motivar y dinamizar a las comunidades indígenas, a partir de una reivindicación del pensamiento propio. Precisamente la escritura de Los pensamientos del Indio que se Educó en las Selvas Colombianas corresponde a un deseo del autor de concretar y sistematizar su doctrina, configurando un texto de estudio que sirviera como guía ideológica para las futuras generaciones indígenas. Este texto, compuesto por 2 libros y 22 capítulos, construido a partir de un lenguaje alegórico y metafórico, Lame hace un recuento de sus experiencias, creencias, visiones y sufrimientos a lo largo de su lucha por la causa indígena.

A lo largo del texto, es posible ubicar varias ideas que lo atraviesan. En primer lugar una reivindicación del autor como vocero de la causa indígena, legitimación que alcanza matices espirituales, con lo que Lame se presenta con una autoridad política y espiritual, donde se presenta a sí mismo como heredero de una tradición de mayores y líderes que ostentan una potestad basada en la sabiduría tradicional indígena, a la vez que como portador de un conocimiento liberador para la causa indígena en nuestro país.

(...) del pensamiento de Quintín Lame; ahí donde ese pensador no le teme al peligro que pueda engendrar fenómenos rastreros la civilización que llegó el 12 de Octubre de 1492 a asesinar cobarde y villanamente a mis antepasados padres de donde desciendo yo, los que habían nacido y habitado en esta tierra Guananí, antes del 12 de Octubre, ya citado; ese 
jardín que me ha mostrado la naturaleza humana hasta hoy, me ordena que no debo temer decir la verdad a ninguno de los hombres por más blanco que sea.(Lame, 1971, 132).

Lo anterior se refuerza en el texto de Lame con la existencia de dos momentos de revelación que claramente establecen su destino político. El primero ocurre cuando tenía seis años y subido sobre un enorme árbol comprende su identidad indígena:

Un roble viejo y corpulento cultivado por la naturaleza, digo la Naturaleza porque sobre él había un jardín de flores las que llaman los civilizados parásitos y nosotros los indígenas Chitemas, dialecto de mis antiguos Páez. Sobre dicho roble en la edad de seis años, trepado sobre él alcancé a contemplar un árbol elevado, es decir, con una copa altanera y orgullosa que coronaba las vírgenes selvas que me habían visto nacer a mí, como a mis antepasados, antes y después del 12 de octubre de 1492, y este era un árbol llamado Cedro del Líbano, parecía que saludaba a las Omnipotencias una humana y otra divina al pasar los cuatro vientos. (Lame, 1971,6)

El segundo momento de revelación ocurre cuando Lame se encontraban en la cárcel de Popayán en1916. Esta vez la revelación se narra en medio de la descripción de las injusticias de la persecución y el presidio. La imagen de su pensamiento es una sabiduría que lo llena de confianza en la justeza de su causa.

La imagen del pensamiento dos veces la conocí, y la conocí lleno de embeleso a pesar de haber pasado como pasa el relámpago que rompe el soberbio manto que tienen los dioses de la oscuridad en altas horas de la noche; el viajero de repente mira por medio de dicho relámpago el traje azul con que se viste la Naturaleza. Así conocí yo también esa imagen ya citada en el presente después de once meses de estar incomunicado en uno de los calabozos de la Penitenciaría de Popayán, sindicado autor de delitos, creados por célebres inteligencias 
capitaneadas por un poeta... imagen que yo la mire lleno de embeleso con una fe más alta que la de Moisés caudillo del pueblo de Israel... esa imagen me llenó de embeleso en embeleso, y de imagen en imagen. (Lame, 1971,15)

La segunda idea que recalcará Lame en su escrito es el origen de su sabiduría en la naturaleza. Partiendo de lo anterior, justificará su lucha como una batalla por la humanidad del indígena, que justifica explicitando el origen propio de su pensamiento y su oposición a la mentalidad occidental colonizadora y racional. En este sentido insistirá en que no tuvo formación intelectual o académica, y que todo su conocimiento partirá de su relación con la tierra: "No es verdad que solo los que han estudiado 15 o 20 años, son los que han aprendido a pensar y son los que han tenido vocación por que han subido del Valle al monte. Pues yo nací y me crie en el monte y del monte baje a escribir la presente obra". (Lame, 1971, 12). Dicho conocimiento, concebido pues en el monte será una revelación de la naturaleza, que aparecerá como maestra espiritual, ética e intelectual de Lame, a la vez que oficia como defensora y guardiana del indígena:

Aquí se encuentra el pensamiento del hijo de las selvas que lo vieron nacer, se crio y se educó debajo de ellas como se educan las aves para cantar, y se preparan los polluelos batiendo sus plumas para volar desafiando el infinito para mañana cruzarlo y con una extraordinaria inteligencia muestran entre sí el semblante de amoroso cariño para tomar el vuelo, el macho y la hembra, para hacer uso de la sabiduría de la Naturaleza nos ha enseñado, porque ahí en ese bosque solitario se encuentra el libro de los amores, el libro de la filosofía, porque ahí está la verdadera poesía, la verdadera filosofía, la verdadera literatura, porque hay la Naturaleza tiene un coro de cantos y son interminables, un coro de filósofos que todos los días cambian de pensamientos". (Lame, 1971, 12). 
El texto de Lame está estructurado alrededor del conocimiento y respeto por la naturaleza. La armonía de la naturaleza es el núcleo del cual emanan todas las formas de saber que tienen vigencia en los diferentes ámbitos de la vida cultural de los grupos nasas. Esto le permite a Lame comparar su acervo de sabiduría con una enciclopedia en donde se puede beber el conocimiento. El hombre blanco, por su educación, no puede nutrirse de esta sabiduría, pero "un indiecito" como él, es capaz de comprender que: "en la selva madre está este hermoso libro llamado el Idilio; este hermoso libro que titulada la llave de las Ciencias o conocimiento del hombre" (Lame, 1297,68).

Desde esta postura intelectual, la Naturaleza es un espacio armónico donde cada ser ocupa un lugar apropiado, pero este edén ha sido agredido violentamente por el proceso de la conquista de América, que a partir de 1492 inició un desmantelamiento de ese orden primigenio. Por eso, el legado de Quintín no tiene sólo que ver con reivindicaciones políticas inmediatas, sino que posee un referente sagrado profundo.

Una tercera idea que atravesará el texto de Lame, será la de la propiedad ancestral de los indígenas sobre la tierra, sustentada en su relación espiritual con la naturaleza que encarna a la divinidad. Así, pues, la propiedad colectiva de las comunidades indígenas sobre sus territorios, más que sobre títulos legales, se sustenta en la autoridad espiritual que le da al indígena su relación mística con el ambiente. Huelga aclarar, que no obstante, como táctica de lucha política Lame legitimará los títulos legales de propiedad existentes desde la colonia, no como fuente de su dominio sobre el territorio, sino como confirmación del mismo. "Estas tierras son exclusiva propiedad que dio el Juez Omnipotente a nuestros primeros padres (...) quien hubiera dicho entonces, sin tenerlo a locura, que más tarde unos huéspedes ambiciosos habían de arrebatarnos por la fuerza todos nuestros bellísimos jardines”. (Lame, 1971, 21). 
En este punto, a partir de la invasión europea y la consecuente desterritorialización para el indígena, se establecerán las relaciones entre occidentales e indígenas, que tendrán para Lame cuatro manifestaciones fundamentales. En primer lugar, serán relaciones basadas en la explotación del trabajo indígena, relación que expresará el pensador mediante un símil, aclarando que es una relación igual a la existente entre "la abeja trabajadora y los zánganos ociosos que sin trabajar desean comer" (Lame, 1971,22). Subyacente a esta explotación de índole económica, aparece una opresión social y política, en la que el indio no solo es esclavizado y avasallado, sino que se le impide expresarse sobre su condición o mínimos derechos "porque siempre el indígena está debajo de la bota del blanco, como esclavo, y el indio que defiende su derecho es perseguido como a un ladrón y facineroso". (Lame, 1971, 23). Dicha opresión está sustentada en la violencia sistémica, lo que genera una relación antagónica entre occidentales e indígenas, donde se aprecia el dispositivo de control, en la medida que el sistema social, económico e ideológico vigente surten todas las posibilidades para que el indígena sea derrotado y excluido de su condición de sujeto de derecho:

pues el blanco es enemigo acérrimo del indígena que no golpea la puerta del engaño; que no quiere las promesas; que no le vende barato; lo mismo que el empleado público se une al capitalista o latifundista, y al abogado para hacerle perder la finca al indígena, el semoviente. (Lame, 1971, 24).

Ahora bien, esta opresión del indígena a manos del occidental, estará sustentada en una mentalidad racista, que legitima la pérdida de derechos, cultura y propiedad del indígena, y permite establecer una sociedad segregada con una clara división no solo del trabajo, sino del acceso al Estado y al poder: "El indio no puede ir en compañía del blanco a un café, a un 
hotel, a una mesa de convite, por arreglado que esté de vestido, el blanco se rebaja ante los suyos, es mirado de los suyos con soberbia". (Lame, 1971, 25).

Establecida la caracterización de las relaciones de poder que oprimen a los indígenas, Quintín Lame insistirá en ciertos consejos prácticos que eviten que la indígena sea robado o pisoteado, que podríamos entender como un manual táctico para evadir dichas realidades opresivas. En este punto se señalan aspectos como no creer en la amistad del blanco o el mestizo, desconfiar de regalos o halagos de los latifundistas y los comerciantes venidos de la ciudad, el entablar cualquier acción jurídica de forma autónoma sin recurrir a abogados blancos, y el evitar pertenecer o colaborar con los partidos políticos de las élites, liberal y conservador para el caso colombiano:

¿Por qué este rechazo a los dos partidos tradicionales? Por la perfidia de los políticos, quienes se comportan con los indígenas como el seductor con la mujer ingenua: como el enamorado engaña con palabras dulces a su enamorada, hasta el momento en que queda satisfecho etc., y la mujer ya no es señorita, ya no es dama, ya todo el mundo la desprecia, así han quedado los restos de mi raza, engañada, perseguida, pisoteada, así por así son los días de la política para el pobre campesino indígena que baja a las urnas. (Lame, 1971, 30).

A partir de esta exposición de motivos para desconfiar del blanco, y de los consejos prácticos para evitar su engaño y acción opresiva, Lame iniciará la exposición de su concepción de la cultura indígena, reivindicando el pensamiento propio y ancestral, con su cosmovisión, espiritualidad y propuesta ética, como pilar de la doctrina con la que los indígenas deben aferrarse a su cultura y resistir a la opresión de la que son víctimas. Se describirán los restos del pasado indígena, tallados en esculturas, pictogramas y cerámicas, 
como punto de comprensión de una fuerza creativa que elaboro obras y textos sobre la piedra y las más elevadas montañas, obras "ique la cólera de los siglos no han podido destruir!” (Lame, 1971,31).

Se resalta igualmente la actitud del indígena hacia la vida, como un ideal ético admirable en contraposición a los valores blancos marcados por una relación con el mundo mediada por los valores de mercado:

La pobreza del blanco es triste, penosa, vergonzosa, motivo a la envidia y la mala fe de éste con el pobre indígena (...) La pobreza del indio no se conoce, pues el indio viste mal, come mal, trabaja a la estoica todo el día, mantenido con el vicio de la coca o el tabaco; si cosecha está contento, si no cosecha también está contento; si tiene plata está contento, si tiene sal come con sal, si no la tiene como sin ella(...) Y lo que el blanco no, cuando no tiene esto reniega, maldice su misma suerte y queda a la manera de un tronco viejo carcomido por la polilla en un huerto de cultivos(...) Pero el indígena, aun cuando viejo, sentado arranca yerba de su jardín. (Lame, 1971, 32).

De igual manera defenderá las relaciones familiares indígenas, como muestra de su cultura y su forma de ser en el mundo y la historia:

Pues en la casa del matrimonio indígena se encuentra la humildad, la paz y la tranquilidad...allí la matrona de la casa es una legisladora, así como el hombre es un legislador fuera del hogar, y unidos dentro del hogar son los dioses domésticos del hogar. (Lame, 1971, 33).

Entonces, se detendrá en lo que podemos entender como la base epistemológica de su propuesta. Estos valores éticos, y esta cultura ancestral indígena que defiende, provienen de una cultura que guarda memoria de los siglos de las lecciones de la naturaleza. Es decir, a 
partir de una relación mística y milenaria con la tierra, se ha elaborado un conocimiento profundo del universo, del que son guardianes ya actuantes las comunidades indígenas, en tanto es un conocimiento que la divinidad ha puesto en la naturaleza, y esta con paciencia de maestra ha enseñado a los indígenas. De esta manera, el conocimiento reside en la Naturaleza y es en marco de una relación espiritual del indígena con ella donde este obtiene conocimiento:

al indio nacido en la ribera debajo de la sombra de la soledad, soledad que fue la imagen de mi pensamiento para mostrarme donde estaba el precioso jardín de la Lógica que tiene la Naturaleza; donde estaba ese precioso jardín que tiene la naturaleza humana; donde estaba ese lindo y perfumado jardín, el que ha perfumado todos mis pensamientos. (Lame, 1971, 131)

Se entiende así entonces la afirmación radical que inspirará la obra de Lame en el movimiento indígena que confrontan al Estado bajo la consigna que un indígena sin su tierra, no es un indígena, pues solo a través de esta relación espiritual con lo telúrico se concibe la sabiduría.

De igual manera, es necesario mencionar la idea de Lame, de construir la victoria indígena a partir de la resistencia contra el dispositivo de control colonialista "Por medio de mi fe, que dejo escrita en este libro, se levantará un puñado de hombres indígenas el día de mañana, y tomaran los pupitres, las tribunas, los estrados, las sesiones jurídicas...porque las inteligencias de la raza indígena superan y superarán extraordinariamente al blanco”. (Lame, 1971, 35). 


\section{Capítulo 2}

\section{La pregunta filosófica por la historia}

\subsection{El concepto de historia y sus implicaciones metodológicas}

Una vez presentadas las generalidades del texto objeto de nuestra investigación, se hace necesario conceptualizar el término historia y su tratamiento filosófico, como ejes fundamentales del presente trabajo. Es preciso entonces decir que el término historia, proviene del término griego historia que significa conocimiento adquirido mediante investigación o información adquirida mediante búsqueda, o relato cronológico de hechos o informaciones. Es este último el sentido que tiene dicho concepto en los textos aristotélicos, por ejemplo en la Poética, donde el autor señala que:

La distinción entre el historiador y el poeta no consiste en que uno escriba en prosa y el otro en verso; se podrá trasladar el verso a la obra de Herodoto y ella seguiría siendo una clase de historia. La diferencia reside en que uno relata lo que ha sucedido, y el otro lo que podría haber acontecido. De ahí que la poesía sea más filosófica y de mayor dignidad que la historia, puesto que sus afirmaciones son más bien del tipo de las universales, mientras que las de historia son particulares. (Poética, 1451b 1-7)

Como la investigación o búsqueda aludidas suelen expresarse mediante narración o descripción de los hechos motivo de la pesquisa, entonces el concepto de historia adquiere la significación de relato de hechos en forma ordenada y específicamente en orden cronológico, referido a todo lo sucedido en determinado período o foco de interés:

Una historia tiene que tratar no con una acción sino con un período y todo lo que aconteció en él a una o más personas, por desconcertantes que hayan sido los diversos sucesos. De igual modo que dos acontecimientos pueden suceder al mismo tiempo, por 
ejemplo, la batalla naval en Salamina y el enfrentamiento con los cartaginenses en Sicilia, sin concordar con el mismo fin, así también en determinada secuencia de tiempo dos hechos pueden seguirse el uno al otro sin producir un resultado único. (Poética, 1459ª 17-28).

Siendo entonces la historia una narración de hechos o de acontecimientos, el concepto historia ha sido utilizado en varias acepciones, como en el caso de la definición propuesta por Bacon (1988). El filósofo inglés, propuso una clasificación jerárquica del conocimiento, basada en el tipo de saber originado por cada una de las facultades humanas: la Memoria da origen a la Historia, dividida ésta en Sagrada, Civil y Natural; la Razón origina, por un lado, las Ciencias de la Naturaleza, divididas en Metafísica y Física, y por otro, las Ciencias del Hombre, formadas por la Lógica, la Ética y la Ciencia de la Sociedad; de la Fantasía o Imaginación surgen las Artes. Así pues, la historia deja de ser un simple recuento y se constituye en una clase de saber, una ciencia, un discernimiento sobre los hechos fundamentado en la memoria.

Pero dicho cuestionamiento sobre hechos históricos o de la memoria, implica entender que la concepción de historia es problemático, en tanto puede referirse al curso de los acontecimientos narrados o estudiados, como a la ciencia que indaga sobre ellos. Esta ambigüedad es trabajada por Walsh en su Introducción a la filosofía de la historia (2006), quien desde este doble sentido propone dos caminos para la reflexión filosófica sobre la historia; en primer lugar la filosofía crítica de la historia, vinculada a las reflexiones del historicismo, que se ocupa de la disciplina histórica, las formas de conocimiento de la misma, y el hecho histórico. Por otra parte, estaría la filosofía especulativa de la historia que se ocupa de revelar el telos o sentido subyacente de la misma, lo que le daría implicaciones incluso metafísicas. 
Lo anterior puede ampliarse, afirmando que la filosofía crítica de la historia se ocupa de las investigaciones y análisis que se ocupan de la naturaleza de la realidad histórica, de los hechos históricos, de los conceptos fundamentales de la ciencia histórica y de la historiografía, independientemente de la realidad histórica concreta, la cual es traída a colación usualmente a modo de ejemplo y aclaración de las categorías presentadas. Así pues, lo problemas de investigación de la filosofía crítica de la historia, se desprenden del hecho que esta, en vez de ocuparse de ordenar la historia "concreta", interpretarla y buscar acaso su "sentido último", se ocupa de los conceptos por los medio de los cuáles se entiende, o puede entenderse, la realidad histórica, así como de los conceptos básicos usados en la ciencia histórica o la historiografía, lo que conlleva a preguntas como ¿Qué tipo de realidad es la realidad histórica? ¿En qué se distingue la realidad histórica de la realidad natural? O ¿Cuál es la naturaleza de los hechos históricos? Ahora bien, desde una perspectiva epistemológica, es decir a la relación sujeto cognoscente - objeto conocido, la filosofía crítica de la historia está llamada a pronunciarse sobre aspectos como las siguientes: ¿Es el conocimiento histórico un conocimiento de leyes? ¿Es un conocimiento inmediato fundado en alguna forma de experiencia humana? ¿Es el material histórico fundamentalmente conceptualizable o simplemente intuible? ¿Son las leyes históricas distintas o no de las leyes naturales? (Ferrater, 2004, 1652).

Por su parte, la filosofía especulativa de la historia, atañe a problemas como la cuestión de los factores causales y en particular, los factores causales últimos de la historia. Así mismo, aparece aquí la cuestión sobre el sentido último de la historia, que a su vez, implicaría un cuestionarse sobre problemáticas como la existencia de los llamados "factores determinantes de la historia", sean estos materiales como por ejemplo la lucha de clases o la 
relación con las condiciones geográficas, o ideales, tales como el Espíritu o la Voluntad. (Ferrater, 2004, 1652)

Estas perspectivas de análisis de la filosofía de la historia, son susceptibles de ser trabajadas metodológicamente desde una perspectiva de interpretación de la historia, ya sea desde un punto de vista crítico o especulativo. En este sentido, Maurice Beuchot, afirma que la filosofía de la historia es cuestión de hermenéutica:

Lo es en su parte epistemológica y metodológica, para ver los alcances y límites del conocimiento histórico, de la fiabilidad que puede tener, así como los métodos e instrumentos conceptuales que le pueden servir para alcanzar lo más que se pueda de conocimiento. Lo es también en su parte ontológica, acerca del ser histórico, del tipo de ser que le compete, en su existencia y devenir. Lo es igualmente en su aspecto antropológico, dependiente del anterior, pues nos enseña lo que es el hombre, a través de lo que ha sido en su proceso histórico hasta ahora, nos hace entrever su naturaleza. Y lo es así mismo en su aspecto ético. (Beuchot, 2011, 152).

Todo lo anteriormente dicho sobre la historia y la filosofía de la historia, tendrá por supuesto repercusiones en los objetivos y la metodología de investigación del presente trabajo. Siguiendo a Beuchot (2011), se propone utilizar una metodología de tipo hermenéutico para la indagación del concepto de historia presente en Los pensamientos del indio que se educó en las selvas colombianas (Lame, 1971). Lo anterior, implica en un primer momento un trabajo centrado en la pregunta por dicho concepto, como eje de interpretación textual sobre el texto de Lame. Pero, de forma coherente con el carácter plurisemántico del término historia, dicho interrogante deberá ser planteado desde diversas perspectivas. Evidentemente se debe iniciar 
realizando una hermenéutica textual que permita conceptualizar lo que entiende Manuel Quintín Lame por la historia. Pero dicho concepto debe ampliarse, para atender a las distintas significaciones que ha tenido dicho concepto. Así pues, siguiendo a Aristóteles (poética) en su definición de la historia como el relato cronológico de acontecimientos, es necesario preguntarse también como ordena Quintín Lame el relato de los acontecimientos históricos, si como un relato lineal o desde otra lógica discursiva, especificando como se hilvana dicho relato. Por otra parte, la concepción de Bacon como ciencia fundamentada en la memoria, nos sirve para desglosar el interrogante por la concepción de historia, primero en un punto epistemológico, que nos exige dar cuenta del tipo de conocimiento que es la historia para Quintín Lame. Por otro lado nos lleva a preguntarnos sobre la relación entre historia y memoria en el pensamiento de Lame y como funciona dicha relación.

Ahora bien, se ha establecido en el capítulo anterior, como Lame construye su texto a través de imágenes, metáforas y alegorías sobre la revelación hecha al autor por la naturaleza, desde la cual se explicita el pensamiento indígena y la relación ancestral con el territorio. Lo anterior, implica un ejercicio hermenéutico específico para un texto no construido desde la racionalidad occidental, sino desde un fundamento epistemológico andina, basado en una explicación espiritual más cercana al pensamiento mítico. Lo anterior, implica un ejercicio filosófico acorde a lo propuesto por Mejía Huamán (2011) en el sentido de establecer las categorías de comprensión del mundo explicitadas en dichas manifestaciones textuales o culturales, y a partir de ellas sistematizar un pensamiento filosófico latinoamericano. En este sentido, es fundamental recordar como desde la filosofía hermenéutica, Gadamer $(1997,31)$ como la narración de carácter o fundamento mítico tiene su lógica propia, basado en una representación o narración diversa del motivo mítico comunicado, que implica "una presuposición de que hay una 
abundancia tal de lo que debe ser narrado y de lo que acontece, que es inagotable" (Gadamer, 1997, 31). Lo anterior genera, una variedad de formas de significación de lo representado que implica "no sólo la ampliación del propio conocimiento del mundo, sino un interés "trascendental" que está por encima de todo lo experimentable." (Gadamer, 1997, 32) Esta experiencia trascendental que buscan representar los lenguajes de origen mítico tiene a su vez una temporalidad propia.

Es cierto que lo narrado es tratado siempre como algo que ha acontecido y, en esa medida, es algo pasado. Pero al mismo tiempo la referencia al presente y a los oyentes del mensaje mítico tiene un carácter constitutivo (...) Mediante una exuberante narración épica, un "recuerdo narra o" llega decisivamente hasta el propio presente. (Gadamer, 1997, 33)

En este orden de ideas, la verdad impresa en estos textos de fundamento ancestral o mítico, radica en una asunción dogmática o racional del mismo, sino en una relación de temporalidad presente y viviente, en que el recuerdo y mención de aquella verdad trascendente explica y origina la realidad presente.

Lo anteriormente expuesto, aplicado metodológicamente a la presente investigación, implica una cierta reconstrucción del pensamiento mítico andino que subyace en el texto de Lame, su verdad trascendente y como a partir de ella se sustenta o significa un concepto de historia. Es decir, implica una interpretación del texto en el sentido de vislumbrar la tradición sapiencial que lo configura, como primer paso para poder conceptualizar a partir del mismo la categoría de historia. Filosóficamente esta es una tarea que en palabras de Gadamer:

Se trata de reconstruir una tradición para la cual no hay en absoluto un acceso directo y que, en tanto en cuanto sabemos algo de ella, ha sido ya atravesada por influencias poéticas y 
filosóficas. Según su más propia esencia, el mito nunca es apresable en su pureza originaria. ( Gadamer, 1997,35)

Por otra parte, una vez establecido el concepto de historia en Quintín Lame, es necesario hacer un análisis del mismo a la luz de la filosofía de la historia, lo que implicará interrogar dicho concepto a las luz de las problemáticas generales tanto de la filosofía crítica como de la filosofía especulativa de la historia( Walsh 2006, Ferrater 2004). Lo anterior, entendiendo el presupuesto hablar de filosofía latinoamericana a partir del pensamiento andino, implica establecer las categorías de comprensión del mundo explicitadas en dichas manifestaciones textuales o culturales, en este caso el concepto de historia en Manuel Quintín Lame, y a partir de ellas sistematizar un pensamiento filosófico latinoamericano, es decir entender que de nuevo nos dice el pensamiento andino en torno a las problemáticas que se ha planteado la filosofía, en este caso la filosofía de la historia.

\subsection{Sobre el desarrollo de la filosofía de la historia en el pensamiento occidental}

Ahora bien, buscar la especificidad del pensamiento andino sobre la historia tal y como se explicita en el pensamiento de Manuel Quintín Lame, implica no solo establecer como la tradición filosófica ha conceptualizado de forma general la categoría de historia o las problemáticas generales que sobre la misma ha planteado el pensamiento filosófico; sino tener un marco general del desarrollo del pensamiento filosófico alrededor de esta temática, que por un lado permita concretar donde se halla la novedad o lo específico en el pensamiento de Lame al respecto, y por otro lado posibilite establecer un diálogo coherente con la naturaleza mestiza del pensamiento latinoamericano.

\subsubsection{Reflexión sobre la historia en el pensamiento griego}


En ese orden de ideas, podemos iniciar fijando nuestra atención en la Grecia Antigua, donde en primer lugar, encontraríamos la visión mítica, recogida por Hesíodo en Los trabajos y los días en su narración del mito de las razas. Dicha narración tendrá una intencionalidad moralizante "feliz afortunado aquel que, sabiendo todo lo que se refiere a los días, hace su trabajo sin ofender a los Inmortales, consultando los avisos celestes y evitando toda falta" (826 828) y relata la creación de los distintos hombres ( de oro, plata, bronce y hierro) que crearon los dioses durante el reinado del cruel Cronos, que progresivamente van siendo eliminados por ofender a las deidades, hasta llegar a la actual humanidad (los hombres de hierro) raza que también está condenada a extinguirse por su propia injusticia, no sin antes oscilar entre dolores y efímeras alegrías. En el texto de Hesíodo, vemos entonces un movimiento de descenso que va desde hombres que vivían "como dioses" (112) en la edad de oro, hasta la quinta edad de los hombres cuya existencia está marcada por el dolor "Tristes sufrimientos agobian los mortales: contra este mal no hay ningún recurso" (197- 201). Se observa entonces una concepción cíclica de la historia, en que se repite el proceso de creación y destrucción de las razas supeditadas al movimiento del Caos primitivo, que se reabsorbe y regenera así mismo. El caos original y final es siempre divino, es decir, eterno. (Teog. 116).Esta estructura de pensamiento, cíclico y caótico irradiará el pensamiento griego. Empédocles se sitúa también en esta estructura de comprensión de la realidad "Más en la medida en que esos cambios incesantes jamás llegan a su finestas transformaciones incesantes jamás llegan a su fin, en ese sentido son por siempre inmutables en su ciclo" (Acerca de la Naturaleza, Frag. 8, 11-12). La realidad temporal es en sus textos un estado de permanente cambio, de contradicción y de naturaleza efímera "en ese sentido nacen y no es perdurable su existencia" (Acerca de la naturaleza, Frag 8, 9). Empédocles, aspira entonces 
a llegar al fin de sus ciclos y poder reintegrarse con el Espíritu Universal, con el Caos, con lo sensible, con lo divino (Aristóteles, 410 b 5-6; 1000 b3).Es pues, un eterno retorno.

Esta cosmovisión cíclica, es igualmente rastreable en el pensamiento de Platón, quien afirmará que el pensamiento científico busca la verdad sobre "una imagen móvil de la eternidad...una imagen que se mueve sin fin respetando el número eterno" (Timeo, 35 - 39). Ese movimiento del universo, corresponde también a la estructura cíclica del universo. "Y es así, por este motivo que han sido generados aquellos astros que recorren el Cielo y que poseen fases diversas. Quiero decir, a fin de que el mundo fuera lo más semejante posible al Viviente perfecto e inteligible; imitando entonces la substancia eterna". (Timeo, 39 D E). En este sentido, vemos que el pensamiento platónico, retoma el pensamiento cíclico de toda la tradición griega como base de una idea del funcionamiento de los astros y la naturaleza, y propende por la investigación de una verdad eterna subyacente a este eterno devenir. Coherente con lo anterior, será el pensamiento antropológico el autor "Pasemos a la existencia de las almas. Estas hacen todo lo que pueden por seguir a los dioses....arrastradas por la revolución cíclica...tienen una enorme dificultad...de fijar sus ojos sobre las realidades" (Fedro 248 A). En este sentido, la temporalidad cíclica sería el mundo de lo engañoso y lo vano, y el fin de la existencia humana es despojarse del ropaje de lo corruptible y mortal, y "llegar a ser semejante a lo divino" (Teeto, 176 B) es decir, participar de la intemporalidad; ser como los astros vivientes y dotados de razón (Timeo 3 C 9).

Será Polibio (1990) como representante del pensamiento de la Roma Imperial quien en su obra Historias, revalorará la temporalidad humana como digna de la reflexión filosófica, aunque manteniendo la estructura cíclica del pensamiento griego. Planteará que la causa del éxito o fracaso de un pueblo es su constitución. Lo anterior se mueve en una temporalidad cíclica, que se 
aplica al proceso de configuración del Estado que incluye una sucesión de formas de gobierno en el siguiente orden: reino, tiranía, aristocracia, oligarquía, democracia, oclocracia. Al interior de los ciclos existe una tendencia degenerativa, punto en el que podemos encontrar una correspondencia con el modelo de pensamiento del mito de Hesíodo. Así pues el reino degenera en tiranía, la aristocracia en oligarquía, y la democracia en oclocracia. Podemos afirmar que en el pensamiento de Polibio existe una dirección cíclica de la historia, impulsado por una ley natural que obliga a la repetición de las etapas. Conforme a su concepción de la historia, Polibio (1990) realiza una interpretación política de la misma, al proponer que la opción ante la sucesión fatalista de los ciclos es el gobierno mixto, que correspondería a una combinación de las formas positivas de gobierno (reino, aristocracia y democracia), cuya materialización generaría un Estado más estable que retardaría los efectos nocivos del fatalismo cíclico de degeneración de las etapas de la historia. Sin embargo, por acción de la ley natural el gobierno mixto enfrentaría su propio proceso de degeneración.

En este sentido, Polibio aporta la lectura de la historia como un proceso universal, dinámico y total. Y dicha universalidad, se expresará en la figura del imperio, supeditado al proceso cíclico estatal ya explicado. De esta forma, la historia como idea de trascurrir cíclico, deviene en una forma política concreta con ambiciones de universalidad, el imperio romano. (Polibio, 1990)

Esta afirmación positiva de la figura del Imperio Romano, tendrá fuertes repercusiones para todo el pensamiento occidental, tal y como analizará Foucault, para quien “ la historia de tipo romano estaba profundamente inscrita en el esquema indoeuropeo de representación y de funcionamiento del poder; estaba sin más ligada con la organización de los tres órdenes en cuyo vértice se encontraba el de la soberanía”( 1998,66) Así pues, la concepción romana de la historia legitimará las pretensiones de universalidad de su metarrelato histórico, elaborando un discurso 
que políticamente fundamenta la autoridad de su soberano pues " estaba en consecuencia necesariamente unida con cierto campo de objetos y con cierto tipo de personajes - con la leyenda de los héroes y los reyes- puesto que constituía el discurso del doble aspecto, mágico y jurídico, de la soberanía"(Foucault,1998, 67). Así pues, el pensamiento clásico pasará de una cosmovisión cíclica de los antiguos griegos, cuyos pensadores rechazaron la reflexión metafísica sobre la historia, en tanto respondía al mundo de la falsedad temporal y vana, a la progresiva elaboración de un discurso centrado en una concepción política concreta, el imperio, metarrelato tejido con pretensiones de universalidad y legitimación política de la soberanía del poder romano. Dicho discurso, afectará toda la cultura Europea, en tanto "Petrarca, en plena Edad Media, hizo una pregunta que me parece estupenda, y en todo caso considero fundamental: ¿Hay algo, en la historia, que no sea el elogio de Roma?” Sostengo que, con esta sol pregunta, Petrarca caracterizó la historia practicada no sólo en la sociedad romana, sino también en la sociedad medieval" (Foucault, 1998, 67).

\subsubsection{Filosofía de la historia en el pensamiento judeo cristiano}

Junto con el discurso de la historia encarnada en una teleología imperial europea, la otra gran concepción clásica en occidente fue la de pensar la historia como un camino ascendente hacia la salvación, producto de creencias religiosas en primer lugar judías y posteriormente cristianas y su respectiva manifestación en la filosofía medieval. "Esta historia, basada sobre el modelo romano y sobre las funciones indoeuropeas, se halló en determinado momento (estamos a finales del Medioevo) en contraste con la historia de tipo bíblico o hebraico que definimos como el discurso del levantamiento y de la profecía” (Foucault, 1998, 66). Este paso de intelectualización religiosa que lleva a las creencias judeo cristianas a convertirse en centro y sostén de la filosofía europea, implica un proceso en el que "de la religión cristiana surge la filosofía cristiana, que 
emprende la tarea de llevar al ser humano a la comprensión de la verdad revelada por Cristo, de manera que pueda verdaderamente realizar el sentido auténtico de la misma. Los instrumentos indispensables para esta tarea los halló la filosofía cristiana, ya en la filosofía griega". (Abbaganno, 1994, 226.).

Ahora bien, es necesario entender que el origen de estas concepciones religiosas se da al interior de la cultura hebrea. La mentalidad judía se desarrolló durante los siglos marcada por un aspecto central en su visión del mundo "El pueblo ha sido creado por la Alianza, y la Historia, con sus acontecimientos singulares, se transforma en el fundamento mismo del existir de cada judío, como participante de un destino nuevo y solidario. Es una historia Santa”. (Dussel, 1966, 52) En este orden de ideas, el primer aspecto a tener en cuenta para comprender el sentido de la historia para los antiguos hebreos, es su visión antropológica, sustentada en el libro del Génesis, según la cual el hombre es el ser superior de la creación, quien gobierna sobre todas las otras criaturas y creaciones de Dios. Así pues, una reflexión sobre el destino de la historia, pasará necesariamente por una reflexión sobre el destino del ser humano, en este caso del pueblo judío, como aspecto comprensivo que encierra e implica el sentido de la historia.

El judío se entiende entonces como un ser creado a imagen y semejanza de su Dios, a quien ve como el generador del sentido de la historia en el momento de la creación. “iEntonces Yahvé dijo, que halla luz, y hubo luz!" (Génesis 1, 3). Ahora bien, ese rol de generador de sentido histórico que tiene la divinidad judía no se agota en el acto de la creación, sino que Dios emerge como la figura central de la historia en tanto es sostén de la misma, la orienta, la valoriza y recrea su sentido acorde al plan divino en cada una de sus manifestaciones ante el pueblo de Israel. De esta manera, Abraham encuentra en Dios (Génesis 12,2) el único apoyo de su existencia 
histórica, que lo lleva a abandonar su origen mesopotámico en la ciudad de Ur, con la única certeza de la promesa divina de salvación para su pueblo.

Esta motivación divina de la historia, reforzada con la aparición de Yahvé ante hombres por él escogidos como Abraham o Moisés, señala entonces la idea de la historia como un acontecer humano con motivación divina. En ese sentido, Dios no actúa directamente en la historia, sino que por su Palabra, se dirige a un hombre libre y consciente. "El clamor, pues, de los hijos de Israel ha venido delante de mí, y también he visto la opresión con que los egipcios los oprimen. Ven, por tanto ahora, y te enviaré a Faraón, para que saques de Egipto a mi pueblo, los hijos de Israel" (Éxodo, 3, 9- 10) Estas acciones de los profetas motivados por Dios, son entonces constitutivas de su ser histórico y explicativas de la concepción hebrea de la historia.

Lo anterior esta sintetizado en el Salmo 105, "Alabad a Yahvé, invocad su nombre, Dad a conocer sus obras en los pueblos" (Salmos, 105, 1) Tenemos entonces acá como Dios actúa en su pueblo, actuación que siempre está acorde a la Alianza "Se acordó para siempre de su pacto; de la palabra que mandó para mil generaciones la cual concertó con Abraham," (Salmos, 105, 8-9). Esta acción se da por intermedio de sus escogidos, los profetas: "Envió a un varón delante de ellos, a José que fue vendido" (Salmos, 105,17-18) “Envió a su siervo Moisés, y a Aarón el cual escogió" (Salmos, 105, 27). Así pues, la historia la efectúa Dios por medio de su servidor, entendido ya este no como una persona singular, sino por medio del pueblo de Israel, la comunidad de la Alianza en su totalidad. En ese orden de ideas, Dussel interpreta de la siguiente manera la historia del pueblo de Israel:

La estructura de la evolución histórica puede resumirse del siguiente modo: En primer lugar existe Yahvé "absolutamente - otro" y libre, que ha creado la Historia por la iniciativa incondicionada de comenzar un diálogo y entablar una Alianza con el hombre. Yahvé es el 
señor y creador, pero al mismo tiempo es el Yo de un diálogo de amor. En segundo lugar, el hombre - "imagen" de Dios (Génesis 1, 27), es el tú del diálogo libre, pero contingente en las tinieblas del sin sentido. En tercer lugar, ese hombre meramente credo, como un ente es constituido por la Alianza como sentido de esa historia (ammanah=fe=comprensión existencial), indicándole así la dirección en que deberá volcar todo su esfuerzo. (Dussel, 1966, 57)

En este sentido, el pueblo de Israel que por medio de la fe dada por la Alianza de Dios con su pueblo conoce el sentido de la historia, está llamado a participar libremente en ella, colaborando y ejecutando como servidores de Yahvé, el plan de Dios, es decir el sentido mismo de la historia. Así pues, mientras para el pensamiento griego el tiempo constituía un eterno retorno, para la cultura hebrea es un proceso lineal, iniciado por la creación, renovado por la Alianza con Abraham, y resignificado por la acción de los profetas inspirados por Dios. Dicha concepción lineal será adoptada por el cristianismo, para quien el momento decisivo de la historia se cristaliza con la venida de Cristo, que señala la plenitud de los tiempos: "Cuando llegó la plenitud de los tiempos, Dios envió a su hijo, nacido de una mujer" (Gálatas, 4,4). Se mantiene la linealidad temporal judía, en un proceso planeado para llegar a una plenitud histórica en el momento de la encarnación del hijo de Dios, como lo señala Pablo en la epístola a los Efesios: "que en él había proyectado desde antes, a la economía de la plenitud de los tiempos: recapitular todas las cosas el Ungido, tanto las del cielo como las de la tierra" (Efesios. 1, 9-10).

La disputa filosófica entre estas dos visiones del tiempo, la griega y la judía, será central en el pensamiento de Agustín de Hipona, quien por supuesto asumirá la defensa de la visión de la linealidad temporal que parte con la creación de origen divino, esbozada en el Nuevo Testamento y que hunde sus raíces en la tradición judía: “Si pretenden que el mundo es eterno y 
sin principio, y, por tanto, piensan que no fue hecho por Dios, están muy lejos de la verdad"(Ciudad de Dios, XI, 4,2).

Partiendo de dicha concepción lineal, refutará entonces la comprensión cíclica del tiempo, herencia helénica del pensamiento romano. En este punto, centrará la atención en la venida de Cristo y particularmente en la crucifixión como el punto culminante y central en la historia, centralidad que implica que es un hecho único e irrepetible bajo cualquier forma cíclica de realidad.

Ciertos filósofos de este mundo han solucionado diversos problemas por medio de un cierto ciclo del tiempo a fin del cual todas las cosas, en la naturaleza, han de tener una renovación y repetición. Ellos aseguran que en el futuro, la reproducción de los siglos ya acaecidos por los siglos a venir se continuarán sin tener nunca fin...Por ejemplo en tal siglo, un filósofo nombrado Platón instruyó a cierto discípulo en una escuela de Atenas llamada Academia, y si se descendiera hacia atrás muchos siglos innumerables, se encontraría que en otros tiempos separados por largos períodos, pero de duración limitada, el mismo Platón, la misma ciudad, la misma escuela y los mismos alumnos se encontraban reunidos... No podemos admitir esa creencia. Una sola vez el Cristo murió por nuestros pecados; una sola vez resucitó de entre los muertos y no morirá jamás. (Ciudad de Dios, XIII, 13).

Frente a una concepción cíclica del tiempo, que puede verse en el pensamiento mítico griego y oriental, y que adoptó una buena parte de las filosofías clásicas, el obispo de Hipona propone un tiempo histórico, finito, creado. Esta visión de la historia como el transcurrir humano motivado y generado por Dios, se halla ordenada por el plan divino de salvación que atraviesa la concepción de la ciudad eterna y la ciudad terrenal o del pecado; y se orienta hacia el momento 
del juicio final donde se concretará dicha teleología salvífica con la separación de las dos ciudades, donde los salvos experimentaran el sumo bien en la ciudad celestial por toda la eternidad, en contraposición al exterminio de cuerpo y alma que les espera a los no salvos. En este orden de ideas Dios se configura como el impulso del devenir histórico en la concepción agustiniana. Es entonces la historia un acontecer humano, con sentido, con una teología que lo cimenta y explica.

\subsubsection{La filosofía de la historia en la modernidad}

Ahora bien, el giro epistemológico de la modernidad, desatado por el pensamiento de Descartes llevará a que la historia busque nuevos métodos y horizontes teóricos. En este sentido, el giro moderno del pensamiento implica una ascensión casi que ontológica del concepto de progreso y será en el pensamiento de Kant donde dicha teleología progresista alcanzará un nivel de madurez. En el pensamiento kantiano, el lugar que la teología medieval le otorgaba a Dios en el desarrollo de la historia ha sido remplazado por la naturaleza bajo la forma de razón universal que guía al mundo, y por ende a la historia, usando como instrumentos la razón y la voluntad del ser humano. En ese orden de ideas, en ¿Qué es la ilustración? "Esta organización del mundo a partir de la razón universal está orientado hacia un ideal común para la humanidad, el progreso: “(...) la naturaleza humana, cuya determinación originaria precisamente consiste en ese progresar" (Kant, 1994, 7)

Partiendo de lo anterior, Kant nos confronta con el interrogante desde el cual quiere asumir la comprensión histórica ¿qué puede hacer la razón con lo histórico? ¿Cómo puede conceptualizarse racionalmente el acontecer fundamentalmente irregular? Desde luego, desde la filosofía kantiana, la respuesta a este interrogante se halla en la misma razón. 
La historia, que se ocupa de la narración de estos fenómenos, nos hace concebir la esperanza, a pesar de que las causas de los mismos pueden yacer profundamente ocultas, de que, si ella contempla el juego de la libertad humana en grande, podrá descubrir en él un curso regular, a la manera como eso que, en los sujetos singulares, se presenta confuso e irregular a nuestra mirada, considerado en el conjunto de la especie puede ser conocido como un desarrollo continuo, aunque lento, de sus disposiciones originales. (Kant, 1994,4).

Piensa el filósofo alemán que quizá sea posible llevar a la historia hacia alguna perspectiva de sentido, lo que exigirá realizar algunas transformaciones tanto en el concepto de la libertad como en el de la propia razón. La Crítica de la razón pura (Kant, 2005) había establecido que las ideas de la razón no podían ser empleadas para producir conocimiento, puesto que se trataba de conceptos puros no relacionados con la experiencia. No hay, por tanto, posibilidad de conocimiento únicamente especulativo, a base de tales ideas, ya que como decimos, son conceptos especiales que a diferencia de los normales, no representan reglas mediante las que el entendimiento organiza lo dado en la intuición. Sin embargo, es un hecho que la razón tiene una cierta necesidad de ideas trascendentales sin las cuales el conocimiento mismo quedaría disperso y no sería ni siquiera tal. Esto es lo que ocurre con conceptos como "Dios", "mundo", "yo" y por supuesto historia, ninguno de ellos remite a la experiencia. Mediante estos conceptos, por tanto, no se nos proporciona un conocimiento de objetos, no remiten a nada fenoménico, son únicamente ideas. Pero sin ellas no podríamos articular la totalidad de las proposiciones que versan sobre lo más propiamente experiencial o fenoménico, cuando por ejemplo se señala a determinado objeto de conocimiento como fenómeno de la historia. De esta forma estos conceptos, donde insisto ubica Kant a la historia, son fundamentales no para generar conocimiento pero si para lograr una imagen completa de la realidad. Es por esto que existe en la 
filosofía Kantiana un interés por determinar cuál es el estatuto que les corresponde. Y la respuesta a dicho interrogante es que se emplean no solo de manera constitutiva ( cognoscitiva) sino en función regulativa para dirigir la facultad cognoscitiva hacia la producción de una imagen completa de la realidad, lo que satisface el interés de la razón, tanto en su uso puro como en su orientación práctica.(Kant, 2005). La razón encuentra entonces, una vía racional para concebir la esperanza de un ulterior desarrollo de la historia como ciencia. De este modo el confuso panorama histórico se aclara como un proceso regular que parte de disposiciones originarias; en este sentido, los actos que dependen de la libertad, particular y diversa, parecen haber sido ya arreglados por un plan ajeno a la voluntad de quienes intervienen.

No se imaginaban los hombres en particular ni tampoco los mismos pueblos que, al perseguir cada cual su propósito, según su talante, ya menudo en mutua oposición, siguen insensiblemente como hilo conductor la intención de la Naturaleza, que ellos ignoran, ni cómo participan en una empresa que, de serles conocida, no les importaría gran cosa. (Kant, 1994,19).

Para entender lo anterior, es necesario tener en cuenta el concepto kantiano de consideración técnica de la realidad natural. Cuando tiene lugar esta, los objetos de la Naturaleza, son juzgados solamente como si su posibilidad se fundara en el arte. La naturaleza es entonces tomada como un artífice de lo natural, de manera que los fenómenos naturales son tratados como los productos de aquella. De un modo similar cabría decir que, en cuanto producto humano, la historia puede ser considerada una técnica. Al atender a la historia como si atendiera a una intención de la naturaleza se encuentra una manera viable de pensar lo particular como contenido en lo universal, y de este modo los acontecimientos singulares, dispares, contradictorios, pueden ser vistos como tendientes a la unidad. Ese tender, 
constituiría propiamente lo histórico. La idea del plan oculto de la naturaleza responde, por tanto, a un interés puro - práctico de la razón: permite hacer operativa una cierta imbricación entre libertad y necesidad, al tiempo que fomenta la esperanza racional en la consecución de un estado de ciudadanía mundial y promueve el compromiso humano histórico, que se encarnará en la federación de naciones en donde la voluntad común guiara al ser humano al desarrollo de la razón y por ende de la felicidad.

Se puede considerar la historia de la especie humana en su conjunto como la ejecución de un secreto plan de la Naturaleza, para la realización de una constitución estatal interiormente perfecta, $y$, con este fin, también exteriormente, como el único estado en que aquella puede desenvolver plenamente todas las disposiciones de la humanidad. (Kant, 1994, 21)

La concepción kantiana lleva a un viraje en el sentido que se aleja de la historia de los historiadores, para instaurar una filosofía de la historia en sentido moderno. Este sendero inaugurado por Kant, será a su vez recorrido por Hegel, con sus propios alcances e interrogantes.

Hemos observado en estas lecciones como se ha desarrollado la Conciencia hasta el presente; y hemos señalado los momentos capitales de la manera en que el principio de la libertad se ha realizado. El designio fue mostrar que la historia universal entera no es sino la realización del Espíritu y por ende la evolución del concepto de la libertad, y que el Estado es la realización temporal de la libertad...Reconocer que la historia universal es este curso evolutivo y la realización del Espíritu, bajo el cambiante espectáculo de sus acontecimientos, tal es la verdadera Teodicea la justificación de Dios en la historia. 
Desarrollar ante ustedes esta marcha del Espíritu universal, ha sido mi aspiración. (Hegel, 2011, tomo II, 454 -455).

Así pues, Hegel supone la razón del mundo desarrollándose en las particularidades del mismo, en búsqueda de una captación superior de sí, lo que implica que su concepción histórica en que la misma Historia es elevada al nivel de potencia superior, el lugar de cumplimiento del Espíritu Absoluto. Esta visión implicará separar la concepción de Historia de la de Prehistoria, en tanto esta es el espacio en donde la conciencia del Espíritu aún no se ha desplegado: "Lo prehistórico, es lo que antecede a la vida del Estado; queda por lo tanto más allá de la vida consciente de sí misma” (2011, tomo. II, 233) La prehistoria es el lugar en el que no sucede nada humana o espiritualmente importante para la historia de la humanidad. Sus habitantes son, por ahora, como jabalíes u hormigas. Más adelante, podrán hacer su historia, pero, por ahora, son sólo naturaleza, ya que la naturaleza precede y prepara al Espíritu. Lo anterior implica, de tajo, una negación de la racionalidad del hombre primitivo, despojando de su conciencia adulta a toda mentalidad que no se circunscriba en los límites de la racionalidad, tal y como esta es definida por la concepción europea.

Dicho despliegue histórico del Espíritu acontecerá en cuatro escenarios concretos, el oriental, (Hegel, 2011, tomo I, 233) el griego (Hegel, 2011, tomo II, 63) el romano (Hegel, 2011, tomo II, 193) y el germánico (Hegel, 2011, tomo II, 279). Evidentemente, nuestro continente queda excluido de la visión hegeliana. Hegel considera que América es el continente del futuro porque no tiene historia. Y no tiene historia porque no ha participado en la historia, ya que ella, a su juicio, es patrimonio de Europa. En otras palabras, no ha encontrado su destino. "América es el país del porvenir...más como país del porvenir América no nos interesa, pues el filósofo no nos 
interesa". (Hegel, 2011, tomo I, 186) Para Hegel, América tiene futuro, pero indica que no lo conoce, porque no es profeta. En consecuencia, América está en la prehistoria.

Metodológicamente, al construir su Filosofía de la Historia, Hegel descarta lo que no es importante, consecuencia conceptual de lo anterior es que desecha a América. ¿Qué implica lo anterior? Ontológicamente la historia no es algo que le sucede al ser humano; es su propio suceder, su modo específico de ser; por lo tanto al estar fuera de la historia América es un no ser.

Contra posturas como las de Hegel y su exacerbado eurocentrismo, se alzarán voces críticas como la de Splenger, para quien es necesario estudiar la historia, partiendo de las particularidades de cada cultura, y no desde la particularidad cultural de quien realiza la reflexión:

Llegamos por fin, al punto en que no es posible dar el paso decisivo y bosquejar un cuadro en la historia que no dependa de la colocación accidental del espectador en cierto "presente" -el suyo- y de su cualidad de miembro interesado perteneciente a una cultura determinada...Lo que ha faltado hasta ahora a los historiadores es la distancia suficiente de su objeto. (Decadencia de la civilización c II; I. p149).

En este sentido, planteará la necesidad de organizar una reflexión de orden filosófica y científica que permita entender el desarrollo de cada cultura como un organismo vivo, y a partir de esas interpretaciones construir una idea general que permita la interpretación del universo como historia. En este sentido, en el texto La decadencia de Occidente, escribirá:

En este libro se acomete por primera vez el intento de predecir la historia... ¿Hay una lógica de la Historia? ¿Hay más allá de los hechos singulares que son contingentes e imprevisibles, una estructura de la humanidad histórica? Los conceptos fundamentales de 
todo lo orgánico, nacimiento, muerte, juventud, duración de la vida. (Splenger, 1966, 1112).

La respuesta a estos cuestionamientos, como ya se ha indicado, será positiva, en tanto Splenger considera: "nuestra tarea se agranda hasta convertirse en la idea de una morfología de la historia universal, del universo como historia” (Spengler, 1966, 13)

\subsection{La historia de los vencidos como perspectiva de análisis}

Ahora bien, es claro en la exposición anterior que el lugar de enunciación desde el que escribe Quintín Lame es diametralmente opuesto al de los autores occidentales anteriormente reseñados. Como ya se indicó anteriormente, estos desarrollos de la filosofía occidental se tienen en cuenta con la intención de entablar un diálogo con la concepción de Lame, pero metodológicamente no pueden ser el punto de partida para la hermenéutica de interpretación de Los pensamientos del indio que se educó en la selva colombiana.

En ese sentido, es más apropiado acercarse a lo que Foucault diseña como proyecto filosófico, y que corresponde a la necesidad de hablar de una historia que no corresponda necesariamente al punto de vista eurocéntrico, sino que permita revelar la concepción de historia de quienes han sido despojados de la palabra, y de su ser en la historia.

Me gustaría mucho escribir la historia de los vencidos. Es un bello sueño que muchos comparten: dar por fin la palabra a quienes no pudieron tomarla hasta el presente, a quienes fueron forzados al silencio por la historia, por todos los sistemas de dominación y explotación... (Foucault, 2012, 55).

Lo anterior tendrá varias implicaciones. Desde un punto de vista metodológico implicará que quienes fueron vencidos "son aquellos a quienes por definición, se les ha quitado la palabra. Y si pese a ello hablaran, no lo harían en su propia lengua. Se les ha impuesto una 
lengua extranjera" (Foucault, 2012, 55) Así pues, la apuesta investigativa, en la que se circunscribe el presente trabajo, de escribir la historia de los vencidos, se ve con la problemática metodológica de la lengua, en tanto a estos “ por estar dominados, se les impusieron una lengua y ciertos conceptos. Y las ideas, así impuestas son la marca de las cicatrices de opresión a la que estaban sometidos”. (Foucault, 2012, 55).

Lo anterior implico un proceso de gradual silenciamiento como dispositivo de control sobre el indígena. Uno de los impactos del colonialismo, se dio en un proceso de progresivo silenciamiento de la voz del Indígena, el cual inició por los elementos de unidad cultural de las comunidades ancestrales, la religión y la lengua. A pesar de que en un primer momento se valoró el rol que podrían cumplir las lenguas indígenas en el proceso de evangelización, paulatinamente estas posiciones se hicieron periféricas, en cuanto se mantuvieron principalmente en las misiones ubicadas en las zonas más alejadas del territorio, mientras que en los centros coloniales de poder se crearon prejuicios sobre la capacidad de las lenguas nativas de expresar los valores y costumbres europeas. (Triana, 1987, 411). En este sentido, el principal argumento para no reconocer a las lenguas indígenas como portadoras de una cultura válida, fue el desconocimiento de la escritura. Por ejemplo, en la crónica de Fray de Santa Gertrudis se puede leer:

Los indios dicen que todos los padres somos brujos, porque dicen ellos: El padre de la Concepción, verbigracia, manda un papel con unos garabatos negros pintados al padre de San Diego lo que dice el padre de la Concepción. Pues esto es brujería, dicen ellos. Ya se ve; como son brutos que no saben que es literatura, les da golpe. " (Fray Juan de Santa Gertrudis, 1970, tomo I, 257) 
Así mismo, aunque existía una posición de amplia variedad de misioneros de utilizar las lenguas indígenas de manera pragmática, como vehículo para la evangelización, cada vez más las autoridades eclesiales consideraron que las lenguas indoamericanas no eran lo suficientemente maduras para expresar la doctrina, situación que implicaba el peligro de herejía. En este sentido, superiores de las órdenes dominica, franciscana y agustina afirmaron en 1582, como lo referencia Triana y Atorvenza, sobre la lengua de los muiscas que:

Tales dialectos eran supremamente pobres en vocabulario, carecían de palabras técnicas cristianas como Cristo, caridad, gracia, contrición, penitencia, etc., o tenían expresiones deshonestas, para traducir a ellas términos como los de encarnación, virginidad, etc., por lo cual sería menos inconveniente obligar a los indios a aprender castellano (Triana, Atorvenza, 1973, 1263)

En este mismo sentido, Pacheco (1973) referencia como en 1606 el jesuita español Gonzalo de Lira afirmaba que:

Dicen los curas que es imposible aprender tan peregrina y dificultosa lengua, y aunque la aprendiesen es imposible poner en ella los misterios de nuestra fe, por ser bárbara y corta para explicar cosas tan altas, por lo cual en lugar de enseñar verdades, vendrían a enseñar errores, por no tener vocablos para algunos misterios. (Pacheco, 1973, 608). Así pues, se estableció de tajo una división entre civilizados, portadores de una lengua capaz de expresar la sabiduría divina, y por otro lado bárbaros incivilizados, portadores de una lengua incapaz e indigna de expresar el cristianismo, aspecto definitivo de la civilización. Ilustrativo de lo anterior, es la polémica acontecida en Pasto hacia 1595 (Ortiz, 1954), cuando las autoridades eclesiásticas constataron como unas monjas hablaban entre sí en lengua indígena: 
Que por cuanto S.S. Rvdma. Está informado que las religiosas deste convento unas con otras hablan en lengua de indio, cosa indecente para su estado, mandaba y mandó a dichas religiosas que de aquí en adelante unas con otras no hablen lengua de indio sino español, en lo cual se encarga a la Prelada del dicho convento para que así lo haga guardar y cumplir castigando con mucho rigor a las que no guardasen este mandato. (Ortiz, 1954, 42).

Esta concepción de las lenguas indígenas, llevo a que se miraran con recelo, en tanto se consideraban vehículos de expresión de "doctrinas falsas" e "idolatrías". En ese sentido, se reseña como el Arzobispo Cristóbal de Torres pidió ante la Corona "la imposición del castellano como un elemento definitivo para asegurar no sólo la unidad confesional del país, sino la extirpación de las idolatrías”. (Triana y Atorvenza, 1987, 474). Dichas idolatrías, son por supuesto, las prácticas ancestrales de la espiritualidad indígena, que al ser juzgadas como bárbaras e incivilizadas fueron perseguidas con saña por los españoles. En este sentido, Pacheco cita la carta del arzobispo Lobo Guerrero al Rey de España en 1599 en la que describía la así llamada idolatría de los chibchas:

Habrá cuatro años que salí a quitarles los santuarios, y se les quitaron muchos en los que idolatraban y hacían ofrecimiento al demonio y a sus falsos dioses, y les quemé la plumería en que también había grande idolatría, y unos se castigaron azotándolos y quitándoles el cabello, que lo tienen por mucha afrenta, y a otros condené en láminas de la plata; y la enmienda y escarmiento fue, que en lugar de la plumería, con ocasión santa de fundar cofradías, dieron en hacer pendones de seda, en los cuales adoraban a sus dioses, y demás de esto hacían otras fiestas con sus borracheras y embriagueces. (Pacheco, 1959,279). 
Central en este proceso de silenciamiento de las lenguas y creencias indígenas, fue el Arzobispo de México, don Francisco Lorenzana, quien a finales del siglo XVIII abogó por el castellano, no solo con fines doctrinales, sino como estrategia "civilizadora" que permitiera enseñar a los indios costumbres europeas. El activismo del Arzobispo Lorenzana contra las lenguas indígenas, llego a impactar a la Corte española, influyendo decisivamente en la promulgación de la Real Cédula del 16 de Abril de 1770, por parte de Carlos III, en la que básicamente se prohibía el uso de lenguas indígenas en los dominios de la Corona Española (Triana y Atorvenza, 1987, 505). En dicho documento de índole legal se puede leer:

A fin de que se instruya a los Indios en los Dogmas de nuestra Religión, en Castellano, y se les enseñe a leer y escribir en este idioma, que se debe extender y hacer único y universal en los mismos Dominios, que por ser el propio de los Monarcas y Conquistadores, para facilitar la administración y pasto espiritual a los naturales, y que estos puedan ser entendidos de los superiores, tomen amor a la Nación Conquistadora, destierren la Idolatría, se civilicen para el trato y Comercio; y con mucha diversidad de lenguas, no se confundan los hombres como en la Torre de Babel. (Velasco y Ceballos, 1945, 81)

Ahora bien, el proceso de progresivo silenciamiento de la voz histórica del indígena, no tuvo solo motivaciones religiosas, sino también de índole política, en tanto se vio en las lenguas indígenas y los discursos provenientes de ellas el peligro de un movimiento insurreccional indígena, sobre todo a partir de experiencias históricas como la rebelión de 1594 en Jalisco, Nueva España, los movimientos de insubordinación andina liderados por Túpac Katari o Túpac Amaru, y las sospechas que levantó en el Nuevo Reino de Granada la figura del 
Cacique de Turmequé. Por ejemplo, Triana y Atorvenza, cita el bando publicado por los españoles en el Perú, tras la rebelión de Túpac Amaru:

Por causa del rebelde, mandase que los naturales se deshagan o entreguen a sus corregidores cuantas vestiduras tuvieren, como igualmente las pinturas o retratos de sus Incas, los cuales se borraran indefectiblemente como que no merecen la dignidad de que no se representen en ningún pueblo de sus respectivas provincias comedias u otras funciones públicas de los que suelen usar los indios para hacer memoria de sus hechos antiguos. Por causa del rebelde, prohíbanse las trompetas o clarines que usan los indios en sus funciones, a los que llaman pututos y que son unos caracoles marinos de un sonido extraño y lúgubre. Por causa del rebelde, mandase a los naturales que sigan los trajes que les señalan las leyes; se vistan de nuestras costumbres españolas y hablen la lengua castellana, bajo las penas más rigurosas y justas contra los desobedientes. (Triana y Atorvenza, 1987, 515)

Una referencia estética de esta problemática en el pensamiento indígena colombiano, lo encontramos en el poema "en verbo ajeno" del poeta yanacona Fredy Chinkagana, que expresa la dificultad para expresar el mundo indígena, obligado desde la invasión española a hablar en "verbo ajeno" a tratar de expresarse desde una lengua compuesta por otra visión del mundo y tratar de entablar un diálogo en marco del silencio que ha impuesto la racionalidad colonizadora.

Hablo de lo propio, con lo que no es mío, hablo con verbo ajeno. Sobre mi gente hablo y no soy yo, escribo y no soy yo. En mí, han llegado espíritus navegantes, del espacio lejano, con cientos de lunas sobre sus cuerpos; vienen desde el dolor y desde el eco de un tiempo; son tierra, son sol, son esperanza para una patria nocturna. Vienen y entonces yo canto, levanto 
mis versos sin venganzas ni odios, sin labios mordidos solo buscando un rincón a mi canto dormido, a la voz de mi gente, desde un verbo prestado. (Rocha Vivas, ed. 2010. 59)

En este orden de ideas, de forma lírica Chinkagana expresa el sentimiento de extrañeza que experimenta el indígena cuando intenta encontrar su propia voz, cuando intenta expresarse desde si identidad y cosmovisión ancestral, oculta en lenguas perdidas y siglos de represión. El poema nos lleva ante una voz poética que debe desdoblarse, renunciar a sí misma, negarse desde una lengua y una racionalidad extraña para encontrarse y tratar de comunicarse con aquella sabiduría que le es propia, aquella herencia de los “espíritus navegantes” emanada de "del eco de un tiempo" que representa la oportunidad de una esperanza de la identidad amerindia. Reflexionando sobre los anteriores puntos, surgen inmediatamente dos interrogantes principales ¿se puede expresar lo indígena? Y más aún ¿se puede conocer lo indígena?

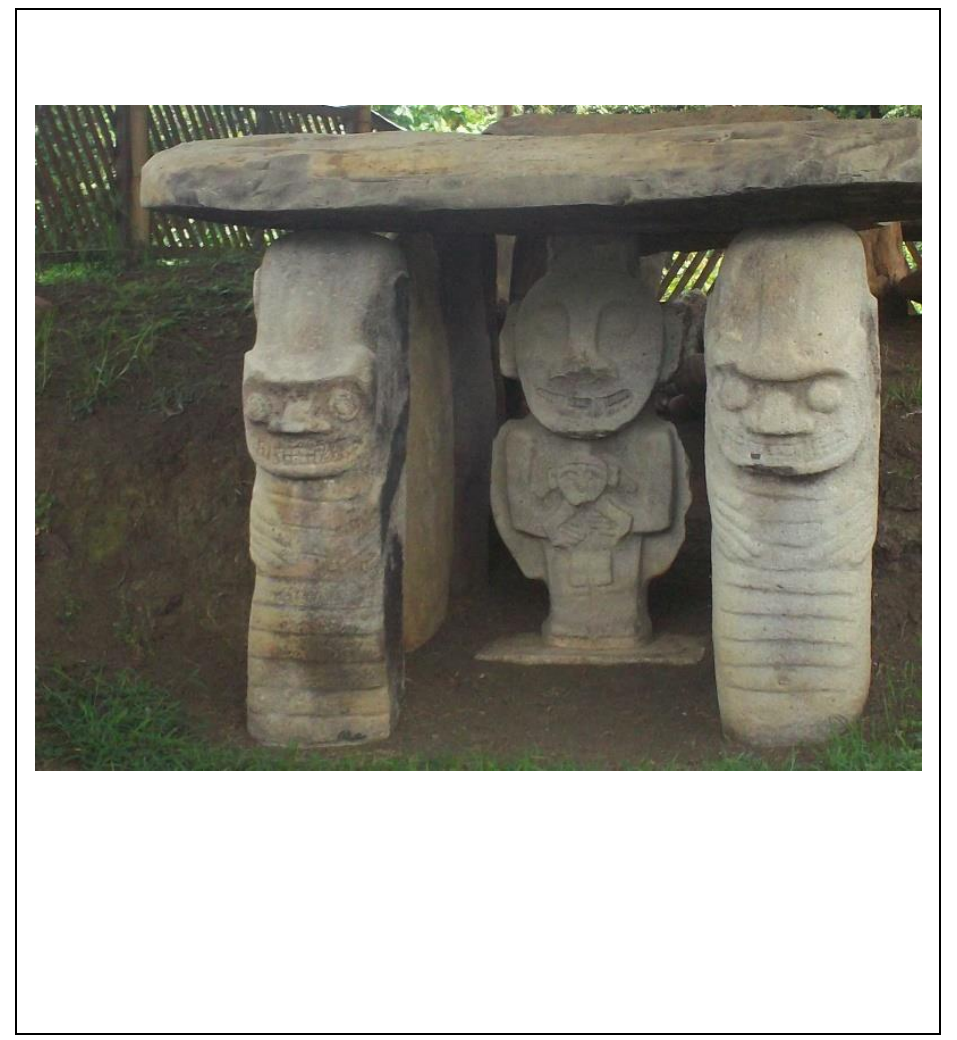


Foto 4. Estatuaria de San Agustín. La falta de comprensión sobre el significado original de estas esculturas nos permite visibilizar la necesidad de interpretar el pensamiento indígena, sino de realizar una construcción metodológica al respecto.

( Fuente: archivo personal, Juan David Sanabria)

Los anteriores cuestionamientos implicarán la necesidad de entender el pensamiento indígena, en este caso concreto el texto de Lame, desde la cultura indígena misma; desde el sentido de una cultura y pensamiento propios, en tanto, siguiendo a Foucault, sólo el pensamiento que pudiera recuperarse a sí mismo en la raíz de su propia historia podría fundar con seguridad lo que la verdad solitaria de los sucesos ha sido en sí misma.(1968) Así pues, se debe entender el determinad modo de entender la relación entre los símbolos lingüísticos que utiliza Lame en su texto y su episteme, es decir

un estudio que intenta encontrar aquello a partir de lo cual han sido posibles conocimientos y teorías; en base a qué espacio de orden se ha constituido el saber; sobre el fondo de que a priori histórico y en el elemento de que positividad pudieran aparecer ideas, constituirse ciencias, reflejarse experiencias en filosofías, formarse racionalidades.(Foucault, 1968. 11).

Ahora bien, la búsqueda de esta episteme andina o ancestral, se halla nuevamente con el punto planteado de la dificultad de plasmar el discurso indígena. Dicha dificultad, trasciende el problema de la lengua, del que ya se ha hablado partiendo del propio Foucault y del poema de Fredy Chikangana (Rocha, 2010), está el problema mismo de la construcción discursiva de dicho episteme, es decir, de los mismos mecanismos de producción epistemológica del discurso indígena, alejados de la racionalidad occidental, a la qué académicamente estamos habituados. Lo anterior lo podemos ver desde el texto que será objeto de nuestra investigación. 
Se trata entonces, en nuestro caso, de efectuar una interpretación filosófica del texto de Lame como actividad en función de una comunidad histórica (comunidades indígenas Colombianas) de categorías usadas implícitamente por la narrativa racional cotidiana que se construye con base (es decir, que hermenéuticamente tiene un doble sentido con respecto a las posibles referencias semánticas). Es decir, tomaremos la narrativa simbólica de Lame para efectuar una labor interpretativa filosófica, que nos permita categorizar la episteme indígena sobre la que se sustenta el texto, y a partir de ella delimitar una concepción filosófica de la concepción de historia para Manuel Quintín Lame. Esta delimitación, deberá no solamente dedicarse a la explicitación de un concepto de la historia presente en el texto de Lame a partir de la episteme andina, sino relacionarlo dialógicamente con las problemáticas que a partir de distintas concepciones de historia se ha preguntado el corpus de la filosofía de la historia, sobre el que se dio un recuento general en el presente texto. Así pues, podemos sintetizar la propuesta metodológica de la presente investigación de la siguiente manera: 


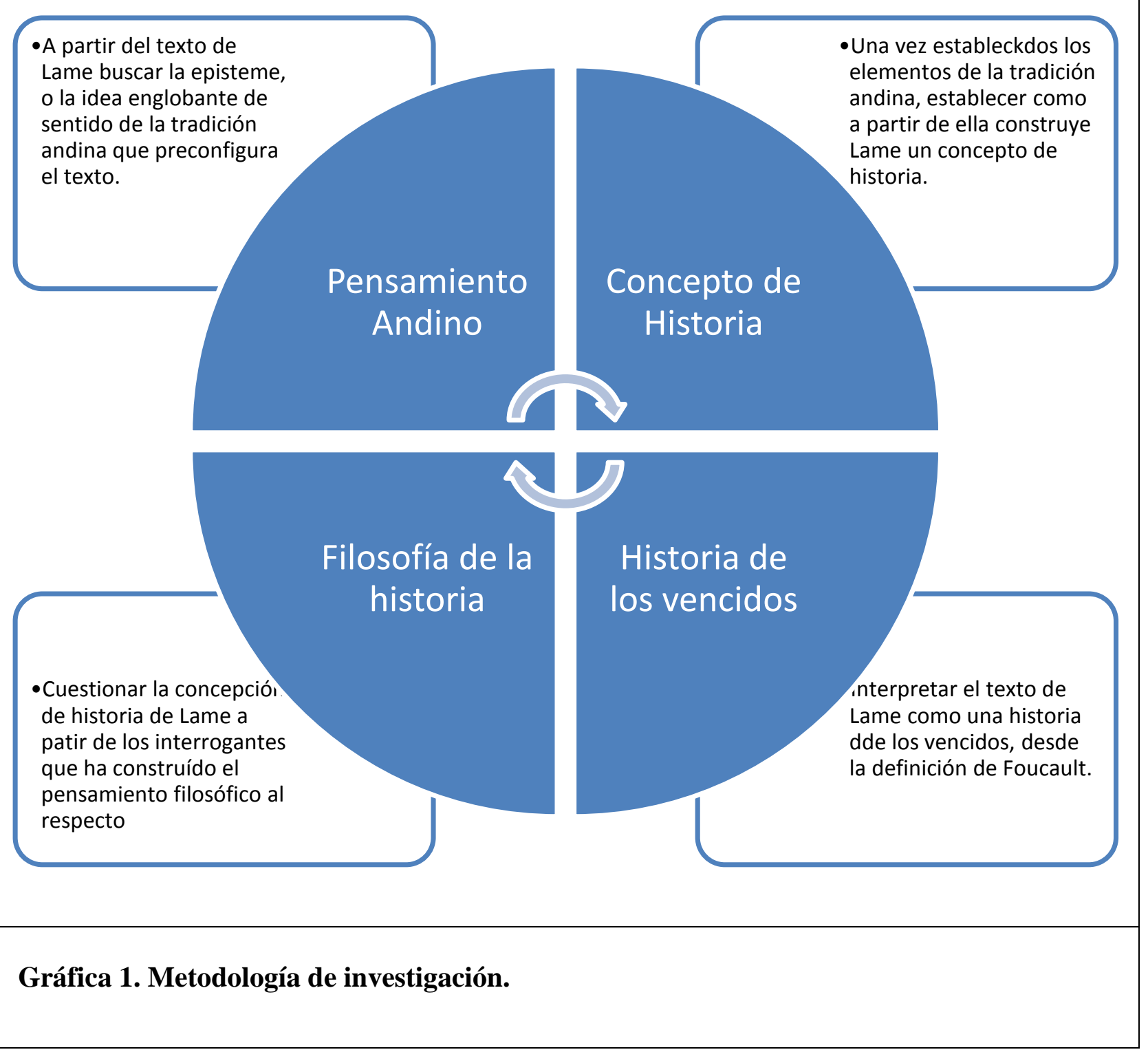




\section{Capítulo 3}

\section{Categorías centrales de la episteme andina}

En el segundo capítulo de este trabajo, se hizo referencia a como el primer paso para una hermenéutica de un texto con las características del de Lame, es propuesto desde el pensamiento de Gadamer (1997), consiste en reconstruir la tradición de pensamiento mítico en la que se fundamente el texto, tradición a la que no es posible acceder de forma directa sino mediada a través de textos. Lo anterior implica, concentrar la atención interpretativa en las estructuras trascendentes que se representan repetidamente mediante imágenes simbólicas en la obra de Lame. Lo anterior, analizado desde el pensamiento de Michael Foucault (1998) implicaría preguntarnos por la episteme o estructura subyacente $y$, con ello, inconsciente, que delimita el campo del conocimiento, los modos como los objetos son percibidos, agrupados, definidos. Así pues, la episteme define el lugar en el cual el hombre queda instalado y desde el cual conoce y actúa de acuerdo con las resultantes reglas estructurales de la episteme. Así pues, es necesario preguntarse por todo un campo de conocimiento que delimita el modo de percepción y categorización, sostenida en el pensamiento ancestral propio de la cultura andina. Para la comprensión de dichos epistemes, resulta útil también la aportación que hace Piaget en el sentido que:

no forman un sistema de categorías a priori en el sentido kantiano, porque contrariamente a estas categorías y al "espíritu humano" de Levi Strauss, que se impone con necesidad de un modo permanente- ellas se suceden en el transcurso de la historia..., no se trata tampoco de sistemas de relaciones observables que resultarían de los simples hábitos intelectuales o de modas coartantes que pueden generalizarse 
en un momento dado de la historia de las ciencias. Se trata de "a prioris históricos", condiciones preliminares del conocimiento, como las formas trascendentales. (Piaget, 1972,29.).

\subsection{La zona cultural quechua}

Para encontrar entonces dichas estructuras epistémicas o trascendentales que fundamentan la tradición en la que se circunscribe Lame, a saber el pensamiento andino, es necesario detenerse un momento en la definición de la propia cultura de los andes. Así pues, siguiendo fundamentalmente a Mejía Huamán (2011) y su teoría de la lengua quechua como instrumento definitorio de la cultura andina, será necesario conceptualizar la categoría de lo andino, y posteriormente a partir de una lectura de las crónicas históricas, justificar la inclusión de Lame en dicha tradición.

Josef Esterman definirá lo andino como un concepto multifacético y polisémico (1998, 51) En primer lugar, señala este autor, es posible hablar de lo andino como una categoría espacial, referida a un ámbito geográfico y topográfico. Esta definición parte de la etimología de la raíz quechua anti que se utilizó en la época incaica para referirse a los pobladores del Antisuyu región oriental del Tahuantinsuyo, según la división establecida por el Inca Túpac Yupanqui, denominación referida por Pedro Cieza de León (2005) quien afirma que se les llamó Andesuyos a los pobladores de la parte nororiental (Paucartambo) del Cuzco. Es decir cubría la parte al este del Chinchaisuyu, parte costeña que contenía los litorales pacíficos del Perú, Ecuador y parte de Colombia.

Ahora bien, aunque el Antisuyu cubría solamente la parte oriental de los andes, es decir desde Quito hasta las Charcas en Bolivia, llegó a dar nombre a todo el espacio montañoso de Sur América, con lo que los Andino, en términos geográficos implicaría la cordillera que se 
extiende desde Venezuela hasta Chile. Esta topografía montañosa de los andes y sus características geográficas particulares, serían condiciones para el surgimiento de un modo de pensar propio y de sobrevivir a las condiciones del medio físico, con los que, continúa la argumentación de Estermann, $(1998,53)$ lo andino pasa de ser una categoría geográfica a tornarse en categoría cultural. Lo anterior no implica una homogenización absoluta de los saberes y tradiciones de los Andes, diversas y amplias, pero si se puede hablar de una cultura común, originada en el intercambio entre comunidades indígenas a lo largo de la cordillera, intercambio que tendría un momento exponencial con el Tahuantinsuyo o imperio inca alrededor de los siglos XIV y XV, y con ello de la difusión principalmente del quechua o runasimi como lengua de intercambio.

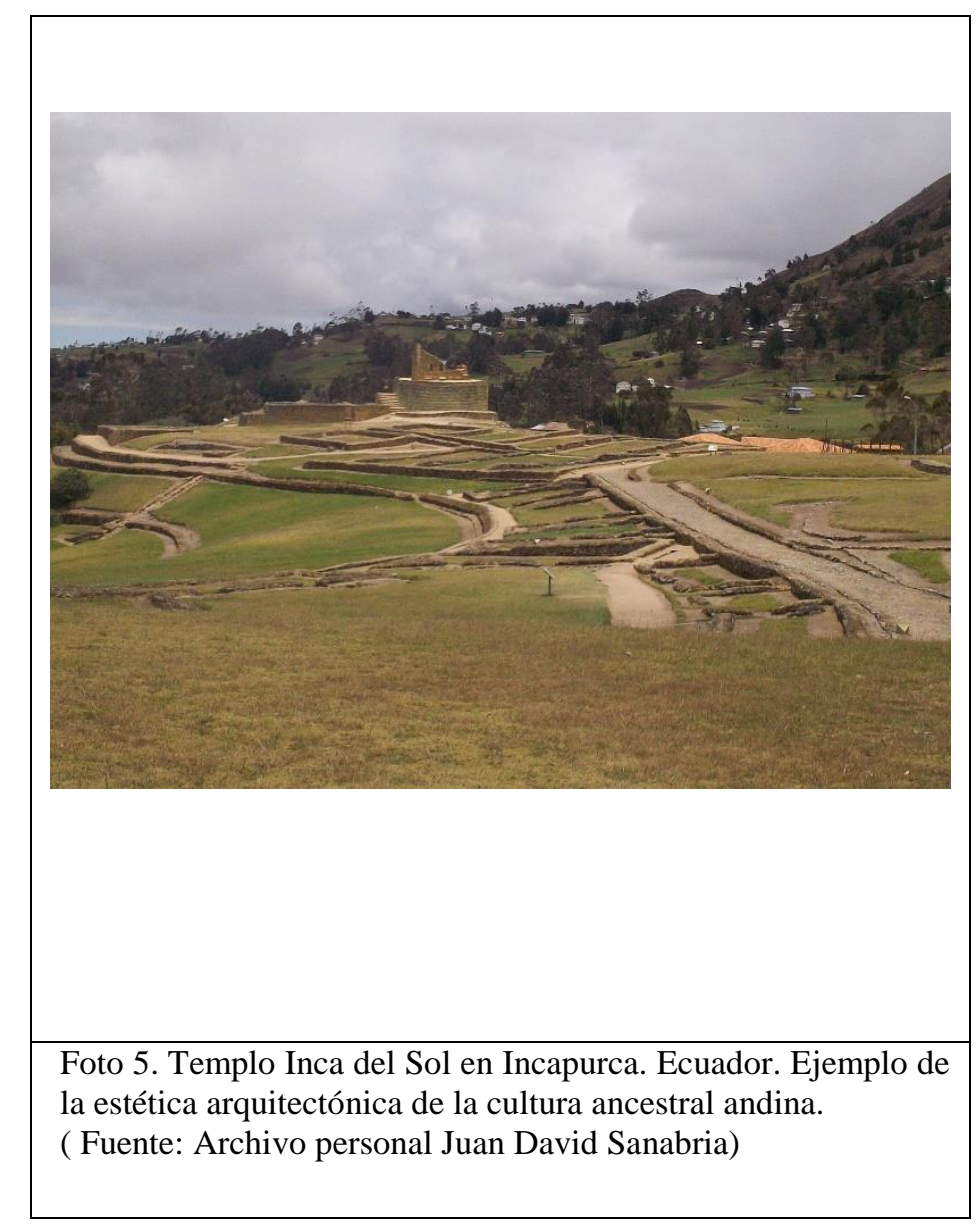


En este sentido, aunque el dominio político del señor Inca llegó en Colombia solamente hasta los departamentos de Nariño y Putumayo (Rostorowsky, 1999) existió una influencia del pensamiento en lengua quechua, que puede sustentar la inclusión del pensamiento de los andes colombianos en el pensamiento andino. En ese orden de ideas, metodológicamente podemos usar el análisis de Miguel León Portilla sobre lo que fue la zona de influencia cultural náhuatl:

Los aztecas o mexicas tan afamados por su grandeza militar y económica, no eran los únicos Representantes de la cultura náhuatl durante los siglos XV y XVI...todos ellos a pesar de sus diferencias eran partícipes de una misma cultura...por sus obvias semejanzas culturales y por hablar una misma lengua, conocida como náhuatl, verdadera lengua franca de Mesoamérica, en una palabra, la cultura náhuatl. (León Portilla, 1974,1).

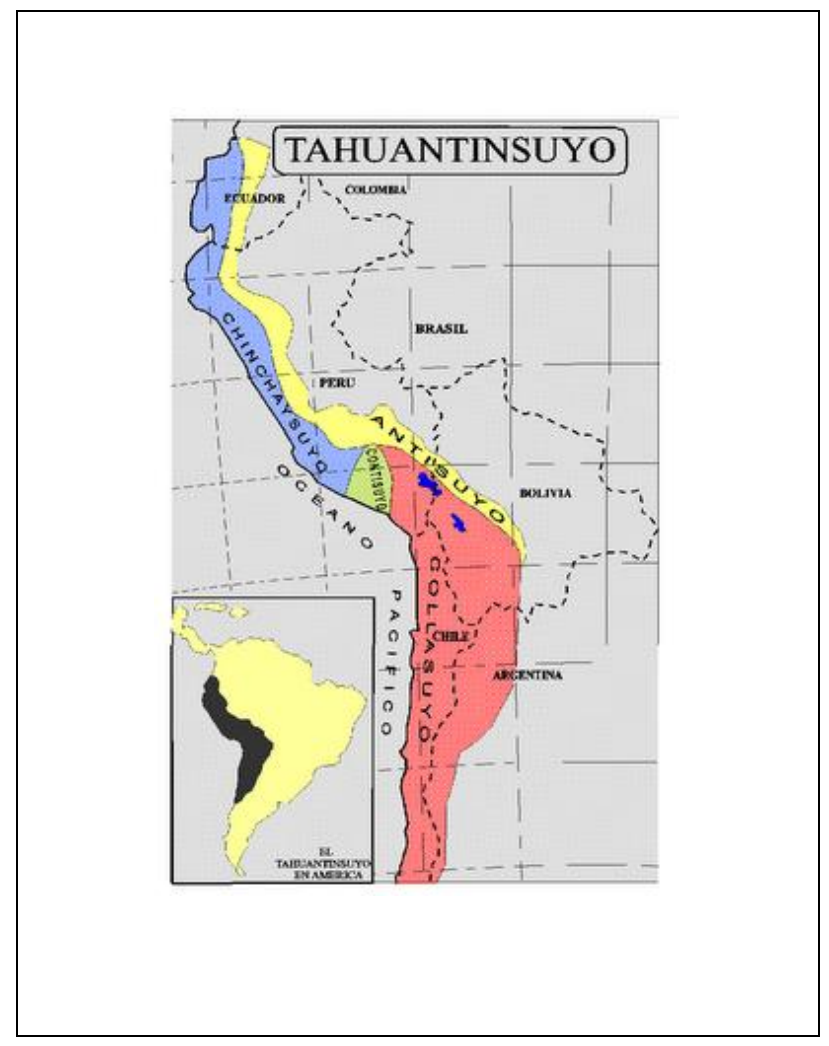




\section{Mapa 1. Tahuantinsuyo o imperio inca.}

Partiendo de lo anterior, podemos rastrear en primer lugar la penetración cultural de la lengua quechua en el marco de la expansión de los dominios incas. Por ejemplo Cieza de León (2005) señala como la pertenencia de amplias porciones territoriales y culturales del actual suroeste colombiano, y su idioma como lengua de civilización desempeño un papel definitivamente importante. Así, el quechua como lengua imperial no significó la desaparición de los idiomas locales, aunque superó totalmente los problemas inherentes a la carencia de unidad lingüística.

Señoreadas estas gentes por los ingas guardaron y mantuvieron las costumbres y ritos dellos, e hicieron sus pueblos ordenados, y en cada uno había depósitos y aposentos reales, y usaron de más policía en el traje y ornamento suyo, y hablaban la lengua general del Cuzco, conforme a la ley y edictos de los reyes, que mandaban que todos sus súbditos la supiesen y hablasen. (Cieza de León, 2005,296).

El proceso de expansión del quechua y por ende de la consolidación cultural de la zona andina, se puede entender entonces a raíz de varios factores. En primer lugar, existía un aprendizaje por parte de los caciques y sus hijos de la lengua cortesana y demás modalidades culturales quechuas en el propio Cuzco, como lo atestigua el cronista Cieza de León:

También llevaban al Cosco, al cacique principal y a todos sus hijos, para los acariciar y regalar y para que ellos, frecuentando la Corte, aprendiesen, no solamente las leyes y costumbres y la propiedad de la lengua, más también sus ritos, ceremonias y supersticiones; lo cual hecho, restituía al curaca en su antigua dignidad y señorío, y como Rey, mandaba a los vasallos que le sirviesen y obedeciesen como a señor natural. (Cieza de León, 2005,45) 
Cieza de León también manifiesta que en el Cuzco y de forma permanente, se encontraban gentes de las diversas regiones sometidas al Inca, pues había indios de Chile, Pastos, Cañares, Chachapoyas, Huaras, El Collas etc. Señalan las crónicas que estos nativos al llegar al Cuzco:

los indios extranjeros podían guardar las costumbres de sus padres y eran reconocidos mediante señales que llevaban en las cabezas. Los Incas no les prohibían a estos indios principales los usos de las tierras con tal que todos adoraran al sol y le hiciesen reverencia. (Cieza de León, 2005, 71)

El segundo medio de influencia lingüística y cultural establecido por los Incas, era el traslado de mitimaes o colonos a las zonas conquistadas, para mantener a los otros pueblos en paz y señoríos.

Los cuales se pasaban a otro pueblo o provincia que fuese del temple y manera del de donde salían; porque si eran de tierra fría eran llevados a tierra fría, y si de caliente a caliente, y estos tales eran llamados mitimaes, que quiere decir indios venidos de una tierra a otra. A los cuales les daban sus heredades en los campos y tierras para sus labores y sitios para hacer su casa. (Cieza de León, 2005, 166).

La llegada de los españoles, en un primer momento, no significó una desvalorización de la importancia cultural del quechua, pues los misioneros dedujeron que debido a la amplia difusión del quechua en Sudamérica lo hacía un instrumento valioso para la catequesis del cristianismo (Zabala, 1985,11). Adicionalmente, debido al problema administrativo que les generaba el mosaico lingüístico de América, en varias zonas del continente se impulsaron las lenguas más extendidas como lengua franca que pudiera usarse para tratar temas administrativos relativos a los indígenas. El quechua, por supuesto, fue lengua franca para la 
zona andina. Este uso del quechua para el dominio español fue igualmente defendido por Humboldt:

Las lenguas americanas tienen una estructura tan completamente distinta del latín, que los jesuitas, que atendieron con el máximo esmero todo aquello que pudiera favorecer la buena marcha de sus establecimientos misionales, introdujeron, para uso de los nuevos conversos, en vez del español, algunas lenguas indias muy ricas, sistematizadas y difundidas, sobre todo el quechua y el guaraní: Por medio de ellas trataron de acabar con los dialectos, más pobres, torpes y de construcción más irregular. (Humboldt, 1982, 97). En el Nuevo Reino de Granada, el chibcha o muisca, el quechua, el siona y el sáliva fueron las lenguas generales utilizadas por los curas doctrineros en el país. De estos, solamente el chibcha y el quechua fueron reconocidos por la corona española. (Triana y Atorvenza, 197, 163). Para el caso concreto del quechua, su escogencia se debió a la existencia de gran cantidad de comunidades quechua hablantes al sur del país, por imposición inca en el período prehispánico. Por ejemplo, existe evidencia testimonial del establecimiento en el Valle de Sibundoy (Putumayo) de un emplazamiento ordenado por el inca Huayna Capac para resguardar las fronteras y entablar relaciones con otros pueblos, asentamiento del que desciende el pueblo Inga, presente actualmente en los municipios de Sibundoy, Santiago y Colón del Putumayo. En este sentido, José Restrepo López en su estudio Putumayo en el tiempo y en el espacio:

De estudios lingüísticos y de tradiciones orales de la comunidad indígena se refiere con bastante certeza que los ingas de Santiago, descienden de migraciones quichuas del Ecuador, entrados por Aponte; y que los ingas de San Andrés provienen 
de otra migración quichua que ascendió por el cañón del río Putumayo y ocupó la planicie del Valle de Sibundoy. (López, 1985,94)

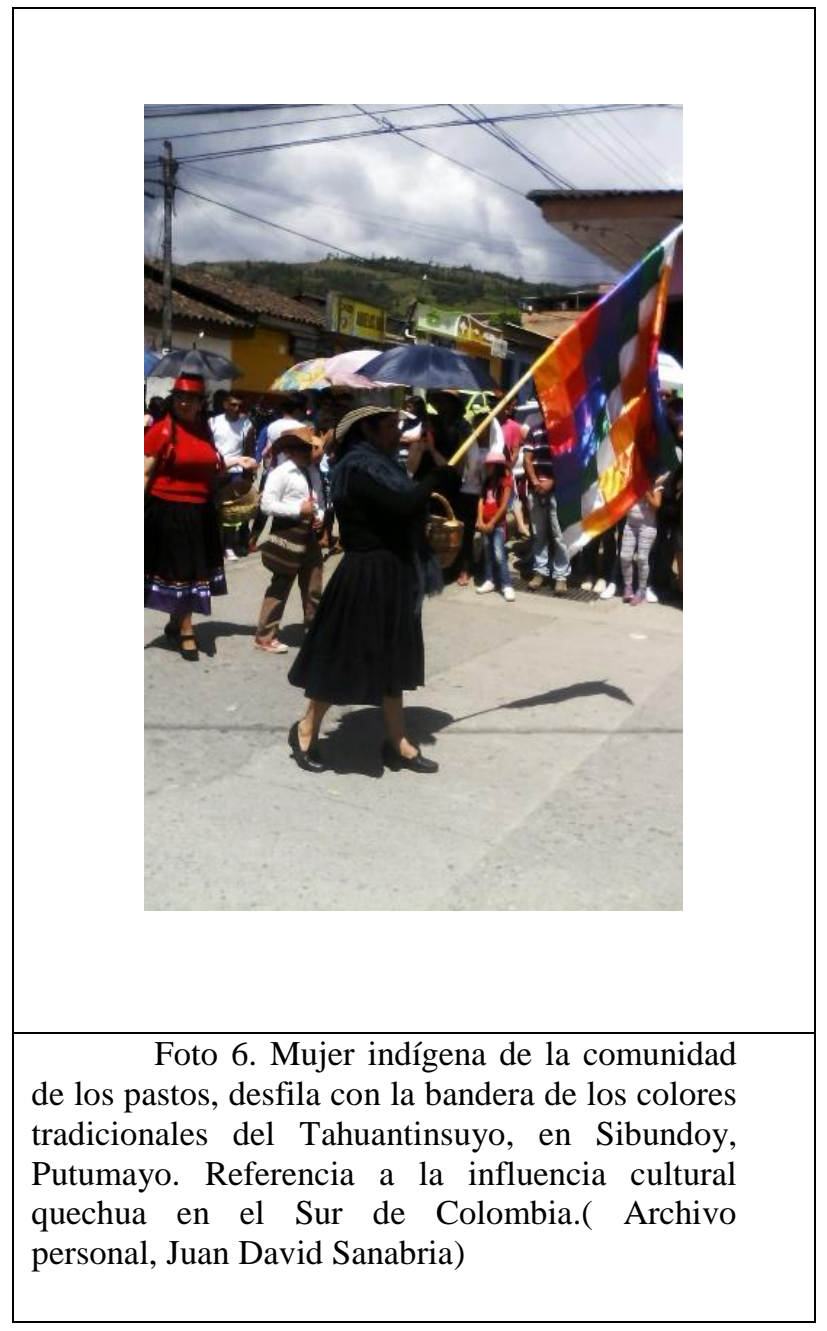

Así mismo, el proceso mismo de la conquista, generó movimientos poblacionales de comunidades quechua hablantes que trajeron su cultura a otras zonas del país. En ese sentido podemos señalar como Belalcázar proveniente del Ecuador, siguiendo con sus expediciones en búsqueda de El Dorado, llegó a la Sabana de Bogotá, donde los indios quechuas que trajo consigo fueron conocidos como Yanaconas (Triana y Atorvenza, 1987, 118). En el territorio 
de Cundinamarca, estos indígenas oficiaron como intérpretes para el proceso de cristianización:

Los indios e indias de Quito y Popayán que vinieron con Belalcázar a quienes también se les repartieron solares con los que trajo Quesada de Santa Marta, más enterados en la lengua y trato familiar con los moscas, les servían de intérpretes y con su enseñanza se bautizaron muchos de los que acudían a la iglesia. (Fray Antonio de Zamora, 1980, tomo I, 272).

Así mismo, el cronista Fray Pedro Simón, señala la influencia cultural que estos indios peruanos tuvieron sobre los muiscas:

y aún traer las camisetas no es hábito de los moscas, sino de los del Perú, de quienes estos moscas lo tomaron de los primeros que entraron aquí con los primeros españoles que bajaron del Perú. Pues el propio hábito de los de este Reino es ceñirse una manta y cubrirse con otro como se ve en los indios viejos que andan así y jamás con camiseta (Fray Pedro Simón, 1982, tomo III, 374)

Otro ejemplo de la influencia de la lengua quechua en el período colonial, lo tenemos en la organización en 1617 del sínodo diocesano de Popayán, en el que se ordenó la utilización del quechua como lengua catequética, como lo referencia Javier Piedrahita en la Historia Eclesiástica de Antioquia.:

Y que por experiencia se ve cuán difícil es a los indios de estas provincias el aprender la doctrina en lengua española y cuán fácilmente entran en ella enseñándosela en la lengua general del Inga en que con facilidad entenderán todo lo cerca de ella se les debe enseñar ordenamos y mandamos que en el distrito de esta ciudad y en el de Almaguer, Timaná, Jámbalo y en el Torimo se les enseñe a los indios la doctrina y catecismo en la lengua del 
Inga (Piedrahita, 1973, 41)

Lo anterior es de particular importancia para la presente investigación, en tanto es una confirmación documental del uso generalizado del quechua en el departamento del Cauca, lo que pone de relieve argumentos para incluir la zona de origen de Manuel Quintín Lame, directamente en la zona cultural quechua. Igualmente, podemos afirmar lo mismo sobre los departamentos del Huila y Tolima, centros de movilización de la segunda etapa del movimiento político de Lame, a través de lo revelado en la crónica del padre fray Juan de Santa Gertrudis: Partió de Honda, e informando de que hasta la ciudad de la Plata era toda gente india, y que hablaban por lo común la lengua linga, la que él había aprendido con leche, metiéndose a predicador misionero"( Fray Juan de Santa Gertrudis, 1970, tomo II, 31) De igual manera, este mismo autor nos da evidencias sobre el uso de la lengua quechua en el Caquetá y el Putumayo, zonas hasta donde también llegó la influencia política de Lame. Frente al Caquetá, señala que las misiones evangelizadoras que allí llegaban dependían de la provincia de Quito, y en ellas indios y doctrineros usaban el quechua: "Ellos hablaban la lengua linga, que es la más general, y de ella eran prácticos los religiosos, porque en Quito se usa mucho" (Fray Juan de Santa Gertrudis, 1979, tomo I, 236). Dirá igualmente este cronista que los indios del Río Putumayo, utilizaban el quechua como lengua general en tanto "de cuantas lenguas hay allí es entre todas la más común y usada" (Fray Juan de Santa Gertrudis, 1970, Tomo. I, 214).

\subsection{La pacha como fundamento y sostén de la episteme andina}

Documentada ya la influencia de la lengua quechua en la zona cultural donde actúo política e intelectualmente Manuel Quintín Lame, partamos entonces de un análisis de las categorías presentes en dicha lengua, puntualmente el de Mario Mejía Huamán (2011) para 
poder interpretar la ya citada episteme de los pueblos andinos. Mejía Huamán señalará que el término runasimi, significa: "idioma humano; el significado semántico de la palabra hace mención al idioma del hombre; esto significa que también existirían otros idiomas; por ejemplo, el de los animales" (2011, 34). Lo anterior implica, una comprensión del ser humano, como un ser más de la naturaleza, que conforma junto a otros seres como las plantas y los animales, quienes también tendrían su lenguaje.

En este sentido, la concepción de la existencia de dichos lenguajes de la naturaleza, se hace explícita en el texto de Lamer. En el libro, la naturaleza, como maestra, no es un ente abstracto o una alegoría de su aprendizaje autodidacta, sino que se puede leer como un texto compuesto por dichos lenguajes naturales desde los que le es revelado el conocimiento a Quintín Lame. Así pues, la idea del lenguaje humano como uno más de los lenguajes existentes en la naturaleza, permite entender en toda su dimensión la recurrencia en Los pensamientos de la imagen de la naturaleza como maestra, como fuente de todo conocimiento. El hombre debe tender a reintegrarse a la naturaleza.

Es entonces a partir de la naturaleza y gracias a ella que es posible el conocimiento y por ende la escritura de Los pensamientos “ ¿Qué cosa es la Naturaleza? La naturaleza es el Libro de Dios y la Ciencia de Dios es infinita" (Quintín Lame, 1971). Evidentemente, y este es uno de los más importantes logros del libro, Lame ve en la naturaleza un texto, la identifica explícitamente como libro:

Aquí se encuentra el pensamiento del hijo de las selvas que lo vieron nacer, se crío y se educó debajo de ellas como se educan las aves para cantar, y se preparan los polluelos batiendo sus plumas para volar desafiando el infinito para mañana cruzarlo y con una extraordinaria inteligencia muestran ante sí el semblante de amoroso cariño para tornar el vuelo, el macho y 
la hembra, para hacer uso de la sabiduría que la misma Naturaleza nos ha enseñado, porque ahí en ese bosque solitario se encuentra el Libro de los Amores, el libro de la Filosofía; porque ahí está la verdadera poesía, la verdadera filosofía, la verdadera literatura, porque ahí la Naturaleza tiene un coro de cantos y son interminables, un coro de filósofos que todos los días cambian de pensamientos; pero nunca salían las murallas donde está colocado el Ministerio de las leyes sagradas de la Naturaleza humana. (Lame, 1971,11).

Permanentemente, Lame compara de modo despectivo los libros donde los blancos creen aprender y los libros que los indios realmente saben leer: "y ese coro de hombres no indígenas que han corrido a conocer los grandes claustros de enseñanza en los Colegios, en las Universidades principiando por las escuelas primarias, etc.; no han podido ni podrán conferenciar con ese libro de la poesía" $(1971,12)$.

Ahora bien, continuando con la exposición de los elementos que señala Mejía Huamán como constitutivos del pensamiento andino, este filósofo afirmará que en los Andes "Se considera al dios inca Pachacamaq, como creador de la naturaleza, del mundo, del espacio y del tiempo."(2011,51) En este sentido, el ser humano había sido creado dentro de una unidad espiritual con la naturaleza, y no aparte de esta: "por ello se hace mención a un creador como Pachacamaq y no a un Runacamaq (creador de hombres)" (2011,51). En este orden de ideas, el hombre creado se concibe no como una creación para dominar la naturaleza, sino como un ser creado para emerger de Paqarinas:

La paqarina es representación del útero materno y la vagina de donde brota la vida; por eso la de palabras en la lengua quechua que alude a la madre tierra o "Pacha mama" a quien hay que adorar y rendir pleitesía en la vida cotidiana con su saludo que se expresa en el t' inkay. (Torres, citado por Mejía Huaman, 2011,53) 
En este sentido, la naturaleza en el texto de Lame, también es referida en términos de una deidad femenina, emergida de la naturaleza, madre del conocimiento natural de los indígenas: “Dios o sea Jehová el verdadero Muschca idioma enseñado por Ollo, mujer que apareció para educar mi raza...pues esta apareció o fue encontrada en las montañas que forman las costas septentrionales de Méjico, etc.” (Lame, 1971,74). Esta analogía entre la naturaleza y Ollo se enfatiza, en que como ya se ha señalado, Lame insiste en haber sido educado por la Naturaleza misma, y añadirá: "si el pensamiento del que se educó en las selvas por medio de esa viejecita Ollo que ha sido y que ha sido y es la imagen de mi pensamiento” (Lame, 1971, 76)

Esta representación femenina del conocimiento natural y del origen de la cultura indígena de una representación femenina, se enfatiza también con la afirmación de la tierra como un vientre en el que descansan los antepasados: "Por qué la cólera de los siglos o de las edades no han podido destruir o borrar hasta hoy esas leyendas que marcan los Cementerios de nuestra prehistoria; Cementerios que se encuentran unos en el vientre de la tierra” (Lame, 1971, 76). Así mismo, es la Naturaleza quien hace nacer al hombre y quien termina con su vida "La Naturaleza, la que hace nacer al hombre y perfecciona la belleza de la mujer, y esta Reina está vestida de un manto azul que nunca se destiñe; ella misma se corona de blancos azahares como una novia que muestra su inocencia al pie de los altares; esta Reina tiene un hermoso libro en su tocador, libro que ninguno de esos sabios de la antigüedad, de la edad media y de la contemporánea han podido conocerlo, libro que tiene fenómenos desconocidos a los conocidos; la Naturaleza termina con la vida del hombre" (Lame, 1971, 84).

Tenemos entonces en Lame, coherente con el pensamiento andino, la representación femenina de la Naturaleza, vientre originario de la vida y del conocimiento. Así mismo, es una naturaleza de la que dependen los momentos vitales del ser humano, el nacimiento y la muerte. Esta idea, 
referiría al concepto andino de Pacha. Este concepto será definido de la siguiente manera por Mario Mejía Huamán: "la acepción pachamama (madre tierra) significa también madre del espacio - tiempo y madre naturaleza" (2011, 147). En el sentido de naturaleza, la pacha, continuará su exposición Mejía Huamán, debe entenderse no en el sentido occidental de mundo o plantea, sino como "todo aquello en el que se encuentra el hombre y lo que está en su entorno, sobre él y bajo él". En este sentido de totalidad, que encontramos también en el texto de Lame, cuando este afirma:

La naturaleza ha criado y cría en el bosque en esos momentos de la charla interminable que tienen los arroyos de las fuentes; en esos momentos que ronca el tigre, ruge el león, silba la serpiente, canta el grillo y la chicharra gime esa paloma torcaz y cruza el bosque, es el momento del recreo que esa maestra que es la Sabiduría, ha ordenado armónicamente a sus discípulos; y después cruzan los cuatro vientos de la tierra que son los sembradores que tiene la Naturaleza, etc. ¿Qué cosa es la naturaleza? La Naturaleza es el libro de Dios y la Ciencia de Dios, es infinita" (Lame, 1971, 14)

Como se puede observar, para Lame, la Naturaleza, es decir la Pacha, compone no solo el contexto biológico en que el hombre habita, sino el conjunto de los seres, de la realidad, incluyendo esta realidad el conocimiento infinito de la naturaleza, es decir una realidad física, vital epistemológica y espiritual. Esto corresponde con lo que anota Mejía Huamán: “en los andes se conoció el término pacha el mismo que puede ser traducido como naturaleza, para referirse al mundo de las cosas reales. Sin embargo, como veremos más adelante, naturaleza también se dice de la esencia de las cosas” (Mejía Huamán, 2011, 155) La pacha es entonces, la naturaleza, entendida esta como origen, esencia, fundamento y manifestación real de la existencia. El ser humano es entonces para el pensamiento andino, y para Manuel Quintín Lame, 
al mismo tiempo, hijo, discípulo, manifestación y habitante de la pacha, es la pacha una realidad trascendente e inmanente al mismo tiempo en la que el ser humano habita, en la que el ser humano física y espiritualmente está.

Ahora bien, también se había señalado que en su conceptualización del pensamiento andino, Mejía Huamán afirma también que la pacha implica tiempo. "En quechua el concepto de tiempo es pacha" (2011,57). Señala el filósofo peruano que de acuerdo al adverbio que acompañe el término pacha, se construye semánticamente la categoría temporal a la que hace referencia. En este sentido, wiñay pacha, es el tiempo de la eternidad, muchuy pacha la época de la hambruna y llaky pacha la época del sufrimiento $(2011,157)$. En este sentido, pacha implica no el tiempo en su acepción de clima, o en las unidades de medición temporal occidental, sino en el tiempo como categoría experiencial, es decir el tiempo de la eternidad emanado de la naturaleza y por ende de la divinidad, o a categorías temporales colectivas para el pueblo indígena, como serían el tiempo de la hambruna o el tiempo del sufrimiento. Así pues, el estar en la pacha aparecería con coordenadas de un momento temporal categorizado a partir de la pacha misma.

Sobre esta acepción temporal, podemos encontrar en la obra de Lame lo siguiente:

Porque ninguno de los mecánicos más afamados que ha nacido la naturaleza humana han podido suspender ese reloj que construyó la mano Eterna de quien hizo la naturaleza y al hombre. Este reloj que vuela sobre la corona del hombre y que nunca se atrasa ni se adelanta, que es lo que llama ley natural legislada por la sabiduría eterna del que ordenó el incansable correr de las aguas y el depósito de ellas. (Lame, 1971. 34)

Así pues, en el texto de Lame, la pacha implica no solo el tiempo natural como categoría, sino la naturaleza como esencia del tiempo, la posibilidad de la temporalidad y por ende de la existencia. En este punto indispensable hablar en este punto de la categoría ontológica que 
propone Rodolfo Kusch para la interpretación de la cultura andina. Debido a que esta cultura se basa en una comunión espiritual con la pacha, la episteme andina se definiría no por una conciencia del ser activo en el mundo, sino por un habitar el territorio, un estar. El estar en la pacha, en la naturaleza, como ya se ha señalado es el fundamento mismo de la existencia americana. "Sólo cabe hablar en América de un probable predominio del estar sobre el ser" (Kush, 1962). El hombre andino es entonces un habitante de la pacha, un ser humano que "está" allí, en medio de una comunión espiritual que le permite proyectarse en su unidad trascendente con el cosmos. Es entonces un concepto que "encierra todo lo que el quechua había logrado como cultura. Supone un estar yecto en medio de elementos cósmicos, lo que engendra una cultura estática (Kusch, 1962)

Entendiendo pues el término de pacha como fundamento ontológico, epistemológico, antropológico y espiritual de la episteme andina, Josef Estermann(1998) habla de la pacha como "el universo ordenado en categorías espacio -temporales" y recalca " pacha el o que es, el todo existente en el universo, la realidad" $(1998,145)$ En este sentido, la pacha corresponde al fundamento último de la episteme andina, en tanto es el conocimiento que emana de la pacha, versa sobre la pacha, detalla la relación del hombre y la pacha en la que está y que lo contiene, y que expone a la pacha como sostén universal y último de la existencia. Así pues, podemos afirmar que coherente con la tradición ancestral andina que recoge, el pensamiento de Lame por completo un conocimiento sustentado en la noción de pacha, y desde allí debemos interpretar su concepción de la historia.

\subsection{La visión andina de Dios y el cristianismo de Quintín Lame}

En el apartado anterior, se llegó a la conclusión de que todo el pensamiento de Quintín Lame descansa sobre la idea de pacha. Ahora bien, una posible objeción a lo anterior, es que Lame se 
declara abiertamente católico "y por medio de la fe creemos todos los católicos que es así" (1971, 33); hecho este que indica que una posible hermenéutica del pensamiento de Lame debería hacerse con base a su fe cristiana que pondría al Dios católico como el centro de su pensamiento y no a la pacha, como hasta aquí se ha afirmado en esta investigación. Para dilucidar lo anterior, es necesario adentrarnos en el tema de la visión andina de la divinidad, definirla como componente o no de la episteme andina, y a partir de allí, ante la evidente fuerza de la religión en el texto de Lame, vislumbrar los aspectos hermenéuticos que nos brinda esta concepción de divinidad en el autor para comprender su visión de la historia.

Mario Mejía Huamán, señala que los pueblos andinos sufrieron un desarrollo en su concepción de la divinidad, que va desde un naturalismo politeísta hasta un monoteísmo. Así pues, Mejía cita como referencia al cronista Garcilaso quien habla de la fe politeísta de los primeros asentamientos andinos, marcada por un culto a:

hierbas, plantas, árboles, cerros grandes, peñascos, los resquicios de ellos, las cuevas hondas, guijarros y piedrecitas, las que en los ríos y arroyos hallaban de diversos colores como el jaspe. Otros adoraban cosas de las cuales recibían algo de provecho, como los que adoraban a las fuentes caudalosas y ríos grandes por decir que les daba agua para sus sementeras (Inca Garcilaso, Comentarios reales, citado por Mejía Huamán, 2011, 165).

De este primigenio culto a los elementos naturales, se desarrollaría una concepción de dioses superiores también definidos como elementos naturales pero que expresan virtudes excepcionales o fuente de elementos necesarios para la vida, como el sol, sobre el que Garcilaso acotara:

representábales muchos beneficios que día a día les hacía y el que últimamente les había hecho en haberles enviado a sus hijos, para que sacándoles de ser brutos los hiciese hombres, 
como los que habían visto por experiencia y, que en adelante verían mucho más andando el tiempo(Garcilaso de la Vega, Comentarios Reales, citado por Mejía Huamán, 2011,171)

Nótese sobre el anterior texto, la gran correspondencia que mantiene con el relato de Lame sobre el sol:

Y que diré cuando la naturaleza de "Muschca", es decir el dios sol hizo aparecer dos sabios mujer y hombre, la mujer para enseñar a hilar el oro y a cruzarlo, es decir a tejerlo, y el hombre, para tallar la piedra y hacer jeroglíficos sobre ella (Lame, 1971, 25)

Tenemos entonces una concepción andina de la divinidad, presente explícitamente en el pensamiento de Lame, que parte de un Naturalismo Religioso, que Mejía Huamán definirá como la fe de los primeros habitantes de los Andes quienes:

Rindieron culto a los elementos de la Naturaleza; en épocas más remotas, a los seres y fuerzas que podían poner en peligro su vida, y posteriormente a aquellos seres que les prestaban algún beneficio o a aquellos en quienes veían una virtud excepcional (Mejía Huamán, 2011, 172).

A partir de este culto a deidades como el Sol, se desarrollará un espiritualismo monoteísta, como lo referirá Cieza de León: "Estos naturales del Qollao dicen lo que todos los demás de la sierra, que el hacedor de las cosas se llama Ticeviracocha y conocen que su asiento principal es el cielo" (Cieza de León, 2005, 238). Este dios supremo estaría también documentado en las crónicas del Inca Garcilaso, en cuyo texto podemos ver como progresivamente va obteniendo mayor importancia en el culto, la idea de un dios supremo de naturaleza más espiritual:

"Demás de adorar al Sol, por dios visible, a quien ofrecieron grandes fiestas, los reyes incas y sus hamawt'as (sabios), que eran los filósofos, rastrearon con lumbre natural al verdadero sumo Dios y Señor...El cual en decir que el Dios de los cristianos y Pachakamaq era todo uno”( Inca Garcilaso, Comentarios Reales, citado por Mejía Huamán, 2011,173). 
Llama la atención como Garcilaso, hombre del período colonial, interpreta la divinidad andina que conoce en analogía con la divinidad cristiana que se impone mediante el proceso de colonización española. En este sentido, es un fenómeno que también podemos encontrar en el texto de Lame: "Muchca es el Dios de la Divinidad, que hizo de la nada lo que vemos y lo que no vemos, y por medio de la fe creemos los católicos que es así” (Lame, 1971,33)

Para Mejía Huamán, esta creciente idea de un dios supremo, que implicaría que a la llegada de los españoles el pensamiento andino transitaba el camino hacia el monoteísmo, se puede explicar de la siguiente manera:

“pensamos que a Pachakamaq o Teqse Viracocha se llega, porque la expansión e integración del Estado Inca, en un momento dado exige la creación de elementos unificadores; por ello los hamawt' as conciben a Pachakamaq como un dios sin nombre, a quien sólo se le conoce por sus obras como creador" $(2011,177)$

En este sentido, aceptando la anterior hipótesis de Mejía Huamán, podríamos decir que a partir del proceso de expansión e influencia de la identidad cultural quechua, sustentada en el ya comentado proceso de expansión lingüística, se popularizo la idea de una divinidad superior que cumplió un rol de aglutinación de la identidad ritual andina, conocido con los nombres como Viracocha o Pachakamaq, quien se entendería como creador del tiempo, la naturaleza, la realidad y el espacio, es decir creador de la pacha. Ahora bien, esta hipótesis de Mejía Huamán, no se detiene a explicar la correspondencia entre los autores andinos a partir del período colonial de esta divinidad con el dios cristiano, a pesar de que la refuerza indicando como esta correspondencia se percibe también en el texto de Poma de Ayala:

Felipe Guamán Poma de Ayala, hace mención a Ticse Cailla Uiracocha en el sentido de que es el mismo dios de los cristianos y a quien hacían invocaciones como la siguiente:.. Señor de 
este universo, ¿dónde estás en el cielo? ¿En este mundo? ¿En el subsuelo? ¿Aquí no más?

Creador del mundo, hacedor del hombre. Dónde estás. Dónde. ¡Óyeme! (Mejía Huamán, 2011, 191)

Esta convivencia de elementos ancestrales indígenas con elementos cristianos, aparece desde otra óptica como una particularidad fundamental de la religiosidad andina, que se expresa como un "mestizaje y sincretismo propio, que no es reducible a un tipo ideal de religiosidad pre hispánica, ni a la ortodoxia romana de la religión católica. Así pues, se trata de un cristianismo andino y un andinismo cristiano. (Estermann, 1998, 260). Este sincretismo, sorprende a primera vista, por el proceso traumático y violento que implicó la cristianización de América. Sin embargo, Estermann lo explica a través de tres elementos de la religiosidad que sustentan este sincretismo y permiten a partir del pensamiento andino, sustentar este sincretismo. (Estermann, $1998,262)$

En primer lugar, la religiosidad andina subyace en la relación espiritual con la pacha. En este sentido, dirá Estermann, "Dios no es substancia sino relación o conditio sino qua non de la relacionalidad universal" $(1998,263)$ Así pues, Dios "forma parte integral de la pacha, como fundamento ordenador del universo, como relacionalidad simbólica del mismo" (Estermann, 199,263). Lo anterior podemos ver, se relaciona con lo ya señalado sobre la deidad andina bajo los nombres de Viracocha o Pachacuti, y tendrá también eco en las palabras de Lame: "Dios, criador y ordenador del tiempo" $(1971,25)$ "porque la Ciencia acompañada de la fe descansa en Dios ordenador del Universo y de la ley natural" (Lame, 1971, 40).

Así pues Dios, para el hombre andino es "la suma de todas las relaciones que posibilitan la vida y el orden cósmico" (Estermann, 1998,264) Lo anterior, implica que Dios, como organizador de la Pacha, es quien posibilita y genera ese nexo espiritual entre el hombre y la 
naturaleza, que gracias a él no pueden ser pensados como entes separados. La presencia divina es lo que garantiza el orden cósmico de la Pacha, y por eso es en esta donde encontramos la divinidad, encarnada en la naturaleza, que surge como manifestación de la divinidad. La divinidad en acto es la Pacha organizada armónicamente. Lo anterior, le da un carácter sacramental a la naturaleza, razón por la que los lugares de culto corresponderán a lugares naturales.

En este sentido Lame afirma que: "en medio de la oración que desencadenó ese Dios de la inspiración allá en esas praderas donde cruza el águila" (Lame, 1971, 21). Otro pasaje de Los pensamientos dirá: "Ha sido es y será, siempre grande el hombre que se eleva primero por medio de la fe a Dios Naturaleza Divina" (Lame, 1971,26) "Oíd las palabras de Dios en los montes en todo este desierto que cruzan en medio de las brisas del bosque" (1971, 30). Así pues, en el pensamiento de Lame, encontramos a Dios en medio de la Naturaleza, debido a que esta es la manifestación de Él, la organización de la pacha es fundamentada y garantizada por Dios “ es la fuente que nunca deja de correr, nunca deja de iluminar la humanidad, porque esa ley que tiene la naturaleza fue nivelada por Dios, quien hizo de la nada al universo"(Lame,1971,43) Podemos concluir entonces, que en Lame encontramos esa visión de Dios organizador de la Naturaleza, pero no como idea abstracta o substancial sino como una realidad viva y presente en la naturaleza, que es sagrada en tanto es la manifestación de la Divinidad, en tanto Dios esta encarnado en los seres de la Pacha, lo que a su vez, implica la sacramentalidad de la relación misma del hombre con la Naturaleza. "Mirad su sombra divina que está dentro de las aguas, las que se mueven y no se suspende el correr de ellas; mirad su sombra en medio de la inmensidad que nos cubre" (Lame, 1971, 82) 


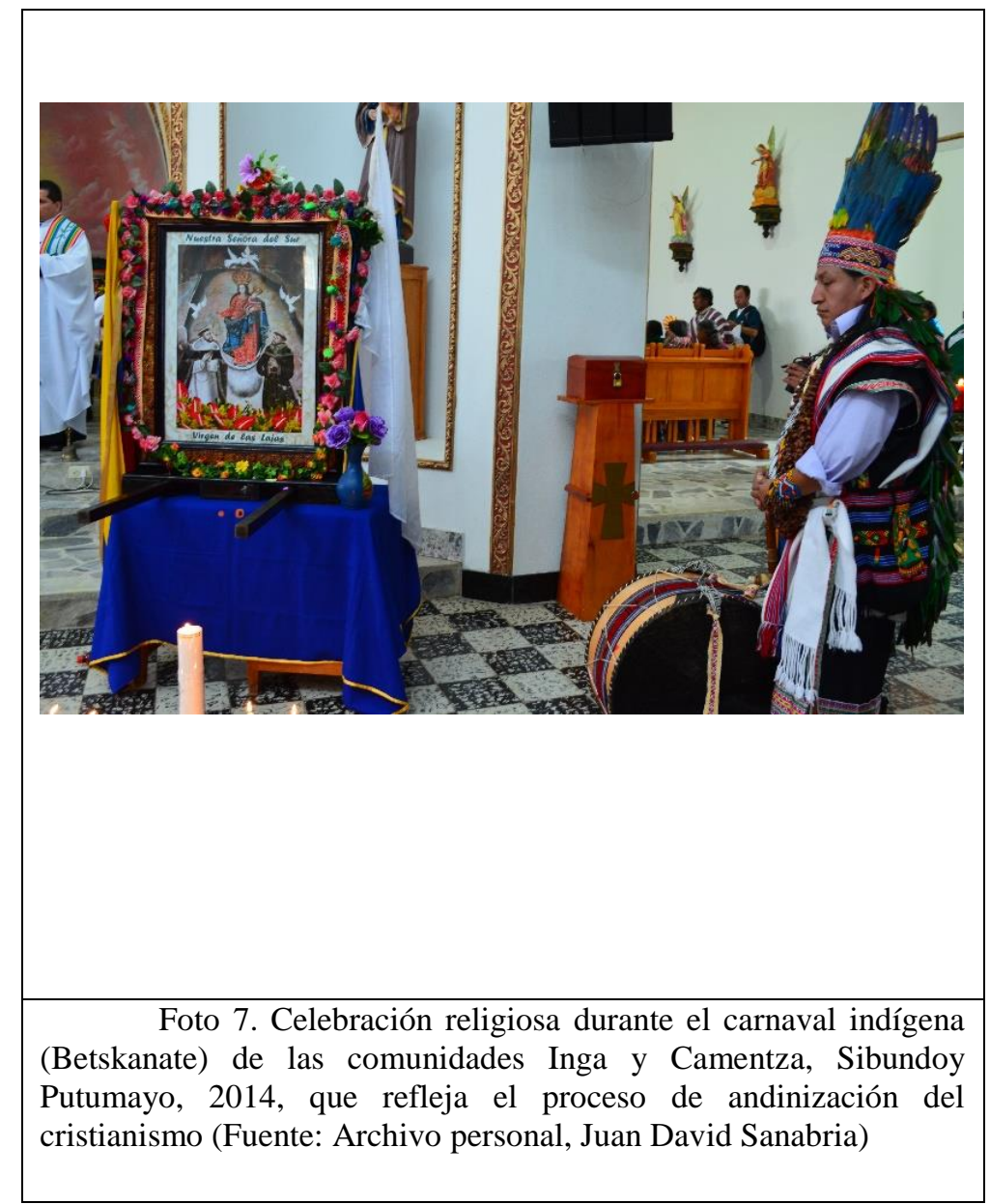

Detengámonos una vez más, en las acepciones más comunes de esta divinidad andina. Pachakamaq, aparece como creador del universo, de la Pacha. En este sentido, según la etimología que ofrece Estermann, significaría "hacedor de pacha". (Estermann, 1998, 267). En este sentido, el sentido de ese espíritu creador sería ante todo la organización del universo, es decir "establecer y mantener el orden cósmico (pacha) a partir de un total desorden y caos". Este es llamado por Lame ley natural (Lame,1971,40), “a la hora ordenada por dicha ley natural se presenta el astro que ilumina a la humanidad, y así todo pasa armónicamente con el hombre y sobre el hombre'(Lame,1971, 34) Esa ley natural, ese orden que genera y garantiza Dios, es el sentido mismo de lo divino, en tanto Dios es "esta fuerza ordenadora" y conservadora del universo, la garantía universal del orden cósmico”(Estermann,1998,270). 
Frente a al nombre de Viracocha, Estermann ofrecerá su investigación etimológica que lo coloca como "Señor universal, maestro de todo lo que existe". Ese término maestro, implica también la dimensión educadora de esa palabra “educador universal" (Estermann, 1998,267) En el texto de Lame, esta dimensión de Dios como maestro universal, aparece en dos facetas. En primer lugar, como ya se ha señalado, como fundamento del conocimiento natural, que la misma naturaleza trasmite, revela a Lame. Por otro lado, también aparece como una divinidad análoga a Viracocha, que se encarga de transmitir las enseñanzas sobre la cultura y las costumbres:

Sinviora, fundador de los templos de la Divinidad del sol y que también enseño a los indígenas cómo debían adorar al solo, como debían ayunar, y cómo debían vivir el hombre y la mujer, cómo se debían casar; que reglamento debía tener o mantener la mujer soltera que tuviera familia y también la viuda que sin volverse a casar tuviera también familia. También dio la medicina a las madres y padres para que disiparan la fuerza o brío cuando la naturaleza ordenara el cumplimiento de su ley al joven varón y a la joven mujer (Lame, 1971,76).

Lo anterior implica, que en el pensamiento de Lame, el conocimiento emanado de la naturaleza, implica no solo una comprensión del orden natural garantizado por Dios, sino del orden social emanado del cumplimiento de sus preceptos sociales. En ese orden de ideas, las enseñanzas de Dios garantizan también el orden social. Tenemos pues una concepción de Dios en Lame basada en los principios de la religiosidad andina. La pregunta lógica sigue siendo, ¿cómo encaja el cristianismo en el marco de esta concepción de la divinidad en Lame? En primer lugar, Lame definirá su fe, de la siguiente manera:

la vida estaba engalanada de la fe, una fe viva y muy alta; fe que me enseñó la prehistoria de mis antepasados cuando elevaban himnos al dios sol en la forma que elevaron sus holocaustos los cristianos antes de Jesucristo al Dios Jehová; ese dios sol de quien 
apenas se asoman los historiadores hoy, y que dicen hablando sobre "El salto del Tequendama del Bochica”. (Lame,1971, 103)

En ese sentido, acorde con su momento histórico donde los pueblos indígenas han pasado ya por varios siglos de colonización y mestizaje, Lame se asume como católico, pero esa fe católica la asume desde la imagen del Dios organizador de la pacha y maestro de los indígenas, que ha aprendido de las creencias ancestrales andinas.

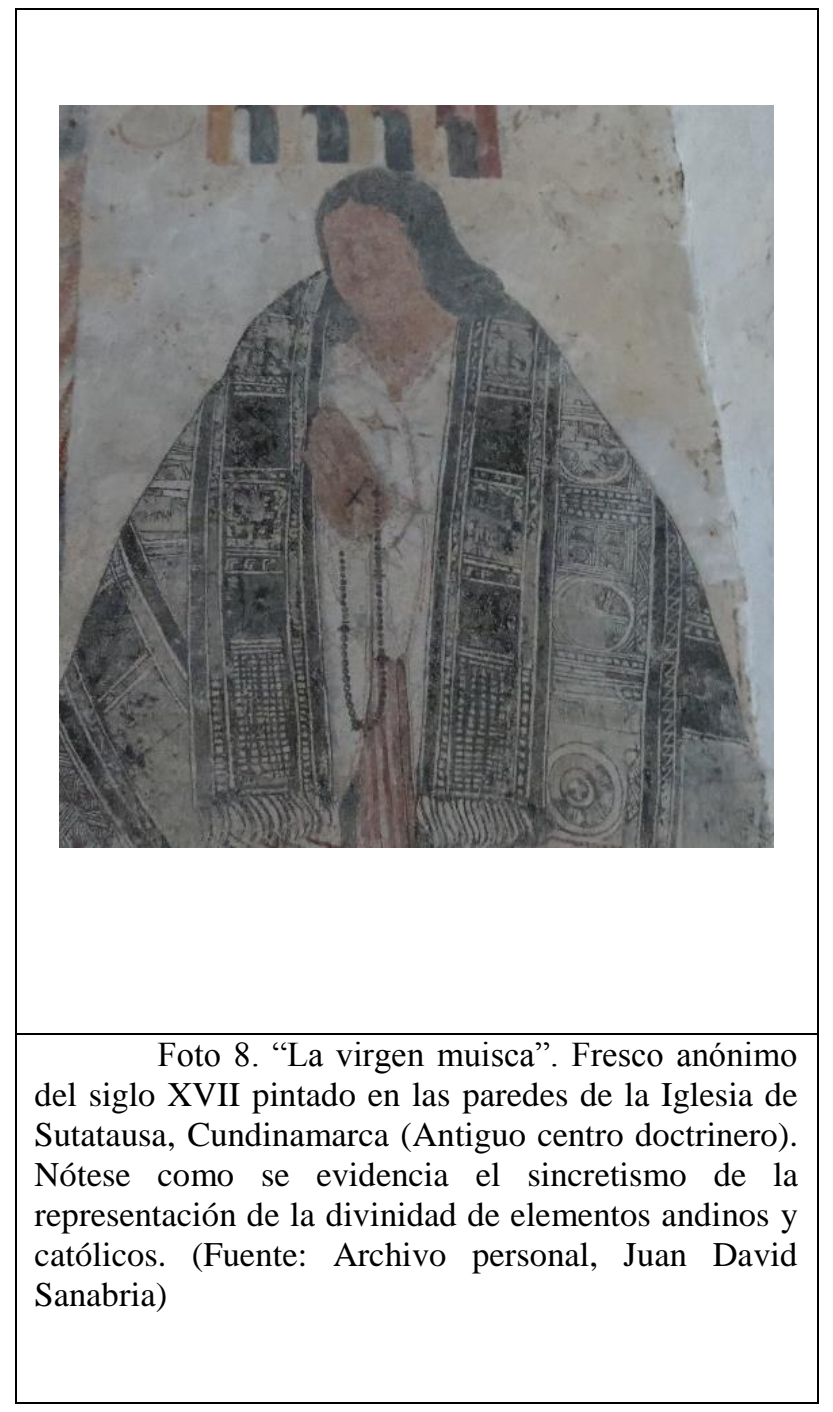

Ahora, bien si analizamos el discurso religioso de Lame, vemos la especial importancia que concede a las enseñanzas del Antiguo Testamento, identificando el sufrimiento indígena con las 
tribulaciones del pueblo de Israel: "Y que diré del pensamiento de Moisés caudillo del pueblo de Israel; que diré del pensamiento de Nabucodonosor cuando ató a tres jóvenes que no quisieron adorar a la estatua; que diré del profeta cuando fue arrojado al redil de los leones; así por así, he caído yo desde mi tierna juventud en el redil de los técnicos de la envidia, de la usura y del sofisma" (Lame, 1971, 102).

Así pues, de la esperanza en la salvación que alimento al pueblo de Israel en Egipto y en el destierro a Babilonia, ha aprendido Lame a tener fe en un Dios que ofrece también salvación, de manera análoga, ante los sufrimientos del pueblo Indígena: "por medio de la fe se le oye en el canto a ese pájaro que es el pájaro de la inmortalidad del hombre cuando pase el alma humano a ser alma inmortal, pájaro que mañana cuando exhale el hombre su último suspiro vuelva a conocer y a cantar en esa mansión, mansión que fue entregad al inocente Abel, , al justo Noé, al caritativo Abraham...mansión que nos espera a todos los hombres que hemos defendido los mandamientos de La Ley de Dios y los hemos cumplido" (Lame, 1971,56)

En este orden de ideas, la fe del pueblo judío en una redención tanto espiritual como terrenal ante la esclavitud y el destierro, aparecen como una fe de esperanza para Lame, quien identifica sus sufrimientos con los de los israelitas. En este sentido, la idea andina de Dios como garante del orden universal cobra relevancia, pues en tanto el desarrollo de la historia indígena se ha visto alterado por la conquista, la redención terrenal que ofrece Dios, tal y como la ofreció a los hebreos en el Éxodo, permitirá recuperar la armonía cósmica que rompió la conquista. En este sentido, llama la atención que durante varios pasajes del texto, Lame hace analogías de sí mismo con el personaje de Noé, hombre Santo con quien Dios estableció una nueva alianza tras castigar con el diluvio a la humanidad por sus pecados. "Digo el maná espiritual, porque de esta sementera disfruto Noé y su familia durante el tiempo que vivió navegando sobre las aguas que 
se tragaron la humanidad, porque era buen cristiano" $(1971,102)$. "enemigos acérrimos del indio Quintín Lame mi persona y que hoy no han podido combatirme y humillarme hasta hoy, como humillaron a otros indios según la historia, pero yo busque la nave de Noé" $(1971,102)$ Podemos interpretar esta identificación con la historia de Noé, desde la concepción del Dios como garante del orden universal. Así pues, así como Dios castigo a los pecadores con el diluvio, para establecer una nueva Alianza con Noé, castigara a los representantes de la opresión colonialista para establecer una nueva Alianza con los indígenas, cuya superioridad ética se plasma en la aplicación del conocimiento emanado directamente de la naturaleza, es decir de la divinidad.

la tierra fue poblada dos veces, la primera por la descendencia de Adán y Eva y la segunda por la de Noé, quien se favoreció del castigo de Dios, por el mismo Dios dentro de una mansión llamada el Arca la que navego, Arca donde yo me he defendido de la calumnia, del cohecho y del perjurio y también del asalto del pensamiento jurídico colombiano y dentro de esa Arca, la que navegó con el indiecito, conocí esa ave dormida de que hale antes en el presente y que al despertarse esa ave, despertó civil y mortalmente mi pensamiento para poderle atacar a la injusticia nacida del corazón de mi enemigo blanco, porque de ahí nació el Diluvio (Lame,1971,59)

Esta idea de orden universal de Dios, inspirada en el Antiguo Testamento, se repite a lo largo del texto, haciendo una analogía entre la Alianza con el pueblo hebreo y la relación de esperanza del pueblo indígena con Dios, y el castigo de Dios a los pecadores y enemigos de su fe en el Antiguo Testamento con el castigo al que se hacen merecedores los representantes del colonialismo, como forma de restablecimiento del orden cósmico y social emanado de Dios: "en manos de sus enemigos es por la poca fe y el desorden de sus hijos como cayeron en el antiguo tiempo las tablas de la Ley que estaban dentro del Arca en manos de los enemigos, pero fue un 
castigo que Dios mandó al desorden”(Lame, 1971, 113). Así pues, el Antiguo Testamento se interpreta en el pensamiento de Lame, a la luz de la idea andina de Dios como garante del orden universal, y de acuerdo a ella la tradición judeo cristiana se convierte para Lame en una fe de la esperanza en la liberación indígena:

Dice un sabio, que el tiempo huye y no vuelve y no es así; el tiempo tiene un guante donde deposita las malas acciones del hombre y lentamente, lo castiga poniéndole su cuerpo como un arco de flecha y le quita todas las riquezas, momento en que el hombre queda sumergido en una calamidad material y civil; el poderoso destronado, el guerrero derrotado y el sabio se acercan a la sombra de la torre de "Babel" y el que cree en Dios que le ama y que espera en Dios; criador y ordenador del tiempo, nunca es derrotado y si es derrotado las derrotas de ayer le sirven para los triunfos de hoy( Lame,1971, 25).

Ahora bien, si la idea andina de Dios como garante del orden universal, es el punto de partida para una lectura del Antiguo Testamento como una fe de la esperanza, dicha esperanza se cristalizaría en la figura de Jesucristo, garante de la redención para el pueblo indígena. Jesucristo es entendido como aquel que vino a redimir a los oprimidos:

que les enseño Dios a los apóstoles cuando junto con ellos subió al monte adoctrinarlos, diciéndoles: "Bienaventurados los pobres de espíritu porque de ellos es el Reino de los Cielos", pero el no dijo Bienaventurados los ricos, los blancos, los jurisconsultos, inteligentes (Lame, 1941,97)

Así pues, a través de la historia de Israel Dios se hace conocer como aquel que actúa en la historia para la liberación de la esclavitud, y certifica su Alianza mediante la revelación de la sabiduría de la Naturaleza, y le da cumplimiento a la redención mediante la venida de Jesucristo. "Así por así se anunció por los labios de los profetas la venida del libertador de la humanidad; 
pero él no vino en favor de los grandes ricos sino a consolar a los pobres infelices" (Lame, $1971,63)$

En este punto, es interesante ver como Lame presenta a Jesucristo. Primeramente parte de la afirmación del origen divino del conocimiento emanado de la pacha

majestad de la inmensidad de las selvas colombianas, las que están mecidas por los cuatro vientos de la tierra, y esa copa altanera ya mecida por los cuatro vientos del cielo, la que desde ahí saluda a ese poderoso mecánico que sancionó las leyes de la Naturaleza. (Lame, 1971,98)

Después de la anterior afirmación, Lame procede a reivindicar el conocimiento de la divinidad en relación a su conocimiento de la Pacha de parte de los ancestros indígenas: “Allá está el templo del dios de los ríos; allá están los templos de los dioses y sus milagros de mis antepasados; allá están los Evangelios de los sacerdotes de mis antepasados” (Lame, 1971,98). Acto seguido, presenta Lame a Jesucristo:

Ese hombre llamado Jesús que es la segunda persona de la santísima trinidad, que es el hombre que constituyó el bien, porque fue el maestro espiritual, quien llamó a todos los niños, curó los enfermos, dio de comer al hambriento, de beber al sediento y dijo pertotanum laboratum en su idioma "guarda los mandamientos cristianos"”(Lame,1971,98)

Nótese como en el anterior texto, da Lame a Jesucristo los atributos de gran maestro del mundo, atribuidos por el pensamiento indígena a Viracocha o a Sinviora en el texto de Lame. Ahora bien, este libertador, identificado con la divinidad andina, realizará la redención mediante su sacrificio, que no es más que la expresión de la voluntad de Dios de estar con los oprimidos y ser con ellos "cordero que fue sacrificado en la Cruz para defender la humanidad" (Lame, 1971,76) La resurrección significa que Dios ha alcanzado la victoria sobre la opresión de modo 
que los indígenas no deberán ser ya esclavos. La encarnación es Dios que carga sobre su ser Divino el sufrimiento y la humillación humana. "Una columna formará un puñado de indígenas el día de mañana para reivindicar sus derechos, como reivindicó Dios la humanidad, es decir, la rescató de la tiranía del demonio; así rescatará la raza indígena sus derechos en Colombia" (Lame, 1971,133)

La fe de Lame no es entonces una adopción del evangelio impuesto por los conquistadores a los indígenas; se trata más bien de la reapropiación del evangelio, que si bien llego de manos de los colonizadores, es reinterpretado desde la concepción andina de Dios, y asumido como una fe de esperanza y liberación a la luz de la situación concreta de opresión del pueblo indígena. Así pues este cristianismo sincrético, construido desde la base del pensamiento andino sustentado en la pacha, es otro elemento importante para la hermenéutica de la presente investigación, en tanto como elemento de la episteme andina en la que subyace el pensamiento de Lame, será un elemento a indagar en la conceptualización de la categoría de historia en el pensamiento de Lame.

\subsection{Generalidades del pensamiento nasa}

Ahora bien, ya se delimitó y evidencia la pertenencia del pensamiento de Lame a la zona cultural andina sustentada en el pensamiento en lengua quechua, y se expuso su pensamiento y religiosidad como manifestaciones de una sabiduría sustentada en la episteme andina que gira alrededor de la idea de pacha. Pero, para poder detallar más explícitamente el pensamiento de este autor, es necesario mirar con detenimiento el pueblo indígena nasa o Páez, del que es originario Quintín Lame, que al igual que otros pueblos de pertenencia a la zona de influencia andina como los Pastos, los Quillasingas o los Otavalos, tiene por su puesto sus particularidades en la expresión de un pensamiento propio basado en la naturaleza, en la pacha. Lame mismo 
refiere a su pertenencia a esta comunidad cuando indica que el sendero de su pensamiento inicia “del indio que saludaba auchingá, buenos días, acuachimuyú, camine, guachumiyú, corra, cuscachí, adiós o hasta mañana: dialecto de los indios Paéz de la cordillera central denominada con el nombre "Tierra adentro” (Lame, 1971,121)

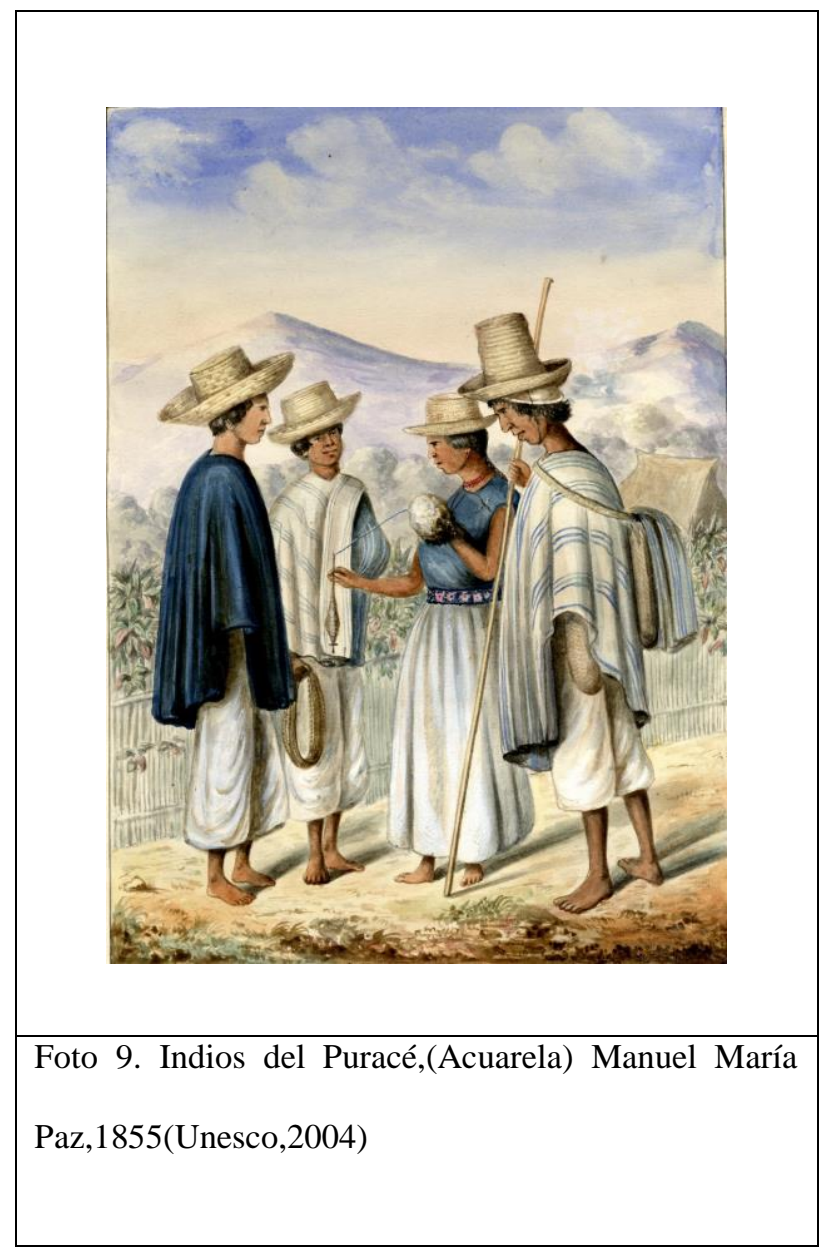

Pedro Cieza de León, se referirá de la siguiente manera a esta comunidad andina:

Y a la parte Oriental está asimismo la muy porfiada provincia de los Páez, que tanto daño en los españoles han hecho, la cual terna seis o siete mil indios de guerra. Son valientes, de muy grandes fuerzas, diestros en el pelear, de buenos cuerpos, y muy limpios. Tienen sus capitanes y superiores, a quien obedecen. Están poblados en grandes y muy ásperas sierras, en los valles que hacen tienen sus asientos, y por ellos corren muchos ríos y arroyos, en los cuales se cree 
que habrá muchas minas. Tienen para pelear lanzas gruesas de palma negra, tan largas que son de veinte y cinco palmos y más cada una, y muchas tiraderas, grandes galgas, de las cuales se aprovechaban a sus tiempos. (Cieza de León, 2005, 93)

Por su parte, en un contexto propio y más contemporáneo, en el texto del Plan de Vida de la Comunidades Nasa del Caquetá, se puede leer:

Los Nasa somos un compendio entre ser humano y naturaleza, que se entrelazan de manera armónica, para construir un todo cósmico, el mundo de los Nasa está constituido por tres regiones: El mundo sobrenatural "sagrado"; el mundo de los espíritus (antepasados) y el mundo natural o este mundo (profano), que interaccionan a través de seres sobre naturales como el trueno; su cosmovisión está movida por relaciones de oposición de fuerzas, buscando un equilibrio entre los estados. El mundo natural o este mundo, corresponde a la tierra considerada como la madre y el eje alrededor del cual gira la vida productiva y medicinal Nasa. Está formada por montañas, paramos, ríos, quebradas, lagunas, planicies, valles, etc. Ella es la fuente de la vida y está llena de poderes que ofrecen a través de los espíritus a personas, animales, plantas y minerales. Para el Nasa este elemento posee alma, Nasa Kiwe (nuestra tierra) es el eje de todos los seres naturales, los cuales deben tener una relación armónica, unos con otros. (Silva, 2004).

Nótese en primera medida, como el concepto de Naturaleza, Nasa Kiwe, se corresponde plenamente con el concepto revisado de Pacha, en el pensamiento andino, y en el de Naturaleza Divina en el texto de Lame, por lo que nuevamente se resalta dicho concepto como el central en la episteme de los pueblos andinos. "La fuente no era brotada por la naturaleza humana sino por los Misterios de la Naturaleza Divina” (Lame, 1971, 122). 
En el texto La metamorfosis de la vida (Yule y Vitonas 2012) escrito en colaboración por Marcos Yule, etnolinguista, y Carmen Vitonas, médica tradicional, ambos de origen Nasa, los autores amplían dicho concepto. Hablan de la tierra como Yat wala (la gran casa), lugar en que se desarrolla la existencia de todo ser, por lo que el territorio mismo se comprende como Yat (casa). Este territorio es a su vez, representación de la primera casa donde vivió Eekthe wala, divinidad denominada como "el mayor sabio del espacio", abuelo que es a una vez creador y ordenador del mundo, reforzando así el argumento que se ha señalado hasta el momento de como la comprensión ancestral andina de la divinidad apunta en este sentido. (Yule y Vitonas, 2012, 91)

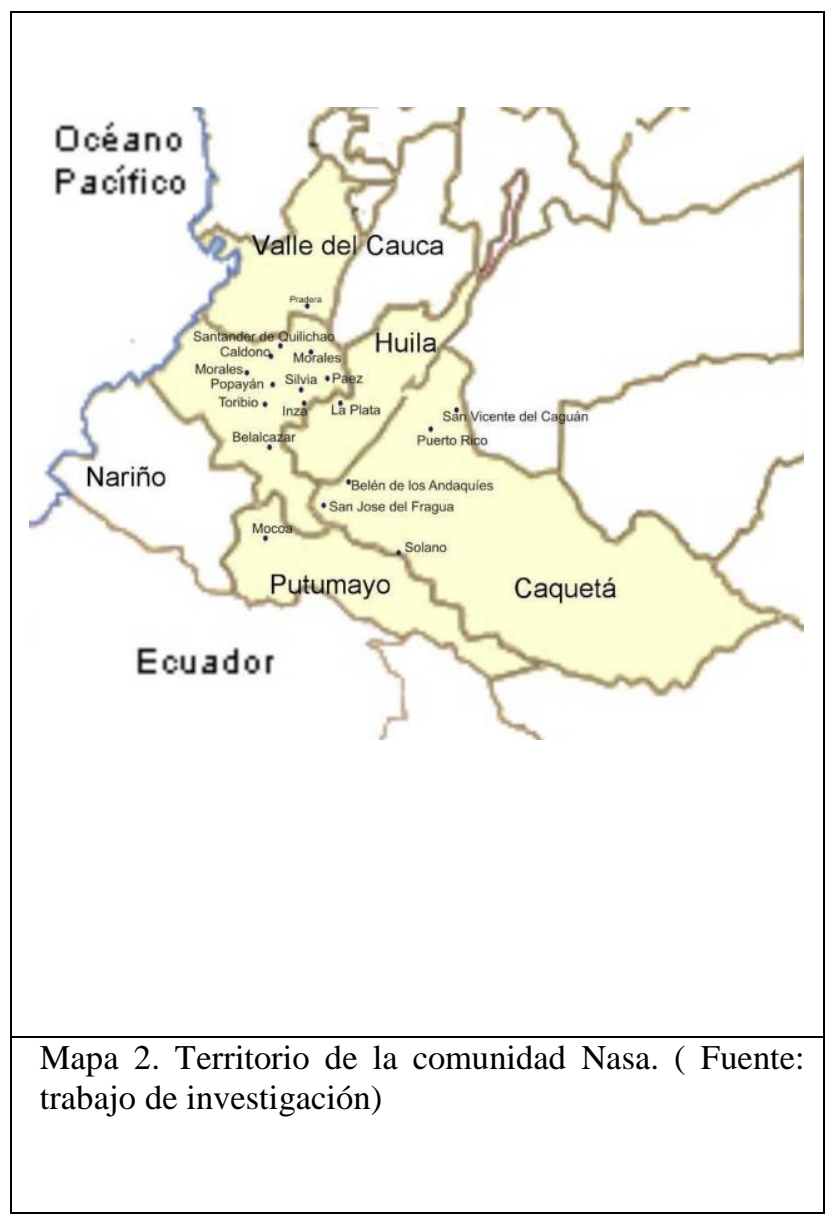


En medio de esta definición de la Naturaleza, surge una visión antropológica derivada de la misma:

podemos concluir que los nasa somos continuidad y contenido del universo, de la tierra o del cosmos. Por eso los mayores dicen que nosotros pensamos desde txiwe uus "corazón de la tierra", desde dentro de ella y por eso concebimos la tierra como Txiwe mama o txiwe nxhi o "Madre Tierra" Nacemos de nuestra tierra, ella nos amamanta y después volvemos a ella. (Yule y Vitonas, 2012,100).

Así pues, el ser humano es comprendido como una extensión física y espiritual de la tierra, de la que depende su existencia, por lo que el nasa solo puede comprenderse a sí mismo en relación a la tierra. Ahora bien, la existencia de la naturaleza y en ella del ser humano se entiende gracias al concepto de semilla, fxiw, que se entiende espiritualmente como pees kupx o regalo de los dioses

El regalo que hicieron los abuelos: El eekthe wala, sabio del espacio, creador del universo, y de la vida y de los abuelos Tay (sol), Uma (Agua) y Ate (Luna). Ellos regalaron a txiwe sat’u y "mujer cacique", que sufre metamorfosis (cambios), la que desescama como el lagartijo o la culebra es decir que cambia. Es el mismo txiwe uus "corazón de la tierra". Es decir: una semilla cambia porque se transforma: nace, crece, se reproduce y cambia, vuelve a su ciclo e origen, ciclo natural. Por lo tanto la tierra es semilla. El txiwe uus se refiere a que la tierra es la semilla porque en su centro está la célula o el embrión en el cuál se origina, se multiplica y se reproduce la vida, es el útero, ovarios de una mujer, por eso espiritualmente a la tierra la denominamos txiwe nxhi "Madre Tierra". La semilla se relaciona con Duu’ya’ja “jigra de parir" útero de la mujer porque la mochila es para guardar semillas (Yule y Vitonas, 2012, 101) 
La vida, pues es para el nasa un constante ciclo de cambio, un estar cambiante en la Naturaleza, donde la vida se desarrolla como una semilla, guiada por el espíritu y el poder de la Naturaleza. "Entonces nuestra vida desescama (cambia) como una serpiente, como una mariposa. Por eso se engendra, se vive, se reproduce y se desescama. Es la metamorfosis de la vida" (Yule y Vitonas, 2012, 5) La Naturaleza entonces siembra la vida como una semilla, para que esta germine, se desescame, cambie como una oruga en mariposa, es este el ciclo vital que bajo el nombre Metamorfosis de la vida, sustenta la comprensión Nasa sobre la existencia humana. “contemplar la sonrisa de todos los jardines sembrados y cultivados por esa señorita que viste de traje azul, y que se corona ella misma de flores y se perfuma en su tocador interminable" (Lame, $1971,123)$.

En este orden de ideas, encontramos como un tercer elemento en el pensamiento de Lame, que sustenta su concepción de la vida, y por ende todo su texto, la vida como germinación y florecimiento de una semilla, como Metamorfosis de la vida. Es idea, junto a la centralidad de la pacha como explicación de la realidad, y la comprensión de la divinidad andina como organizador del mundo y maestro del mismo, y la reinterpretación del evangelio a partir de dicha concepción teológica; serán los elementos constitutivos del pensamiento de Quintín Lame, surgidos en la episteme de los pueblos andinos y configuradores de su lugar de enunciación, desde donde comprende y conceptualiza su visión del mundo, y por lo tanto desde donde hay que comprender e interpretar su comprensión y conceptualización de la historia, en un primer momento. 


\section{Capítulo 4}

\section{Concepción de Historia en Manuel Quintín Lame}

\subsection{El relato histórico en Quintín Lame: Narración simbólica a partir de la confluencia entre mito y hecho histórico en el pensamiento andino}

Establecidos ya como elementos fundamentales de la tradición epistémica andina presentes en el texto de Lame, la idea de Pacha, la religiosidad andina, y la concepción nasayuwe de la metamorfosis de la vida, es tiempo de centrar la atención en la concepción de Historia del autor. Se describió ya en el presente trabajo, como a partir del pensamiento Aristotélico la palabra historia adquiere la acepción de relato ordenado de hechos. En ese orden de ideas, el primer aspecto a analizar en Lame, es precisamente la naturaleza de su relato. ¿Cómo relata Lame la historia? ¿Cómo ordena su relato? Son los cuestionamientos que debemos hacernos en este punto. Ahora bien, coherentes con la metodología planteada debemos hacer una revisión preliminar sobre el relato histórico en la cultura andina.

Según María Rostorowsky (1988), fueron varios los medios con los que los incas conservaron y utilizaron ideológicamente su pasado. Pese a que no contaban con la escritura, los incas y los pueblos andinos anteriores mantuvieron vivos sus referentes de identidad con cantares, quipus y pinturas. En este sentido, la memoria colectiva y la identidad cultural constituyeron aspectos de vital importancia. Por ejemplo, hubo conscientes intenciones de preservar y recrear contenidos ideológicos referidos a los protagonizados por los soberanos del Tahuantinsuyo, los líderes regionales y locales, que se activaban en la memoria de forma paralela y análoga a sucesos antiguos y míticos (Rostorowsky, 1988,187). 
Los cronistas españoles que se interesaron por descubrir el pasado de las Indias, recurrieron a los quipus, sistemas de significación construidos con nudos, para que les narraran la versión indígena de la historia. Estos informantes emplearon coloridas y complejas cuerdas con nudos para registrar los hechos más importantes del Tahuantinsuyo. Al parecer, según el orden de los hilos principales, y secundarios, los lugares y las asociaciones, de acuerdo también a los colores, los quipus recordaban y narraban hechos destacados referidos a los señores Incas. Así, se conoció la versión indígena de la historia, prehispánica en una unidad narrativa que incluía hechos, símbolos, asociaciones míticas, pasajes específicos, datos y otros contenidos. (Randall, 1987,291) Estas referencias míticas en el discurso histórico, fue un mecanismo narrativo común en los Andes, donde la verosimilitud de las narraciones míticas no fue cuestionada sino asumida como parte de la historia (Zuidema, 1977,47)

Sobre lo anterior, encontramos en Cieza de León que:

Usan de una manera de romances o cantares, con los cuales les queda memoria de sus acontecimientos, sin se les olvidada, aunque carecen de letras. Y entre los naturales de este Collao hay hombres de buena razón, y que la dan de sí entre lo que les preguntan y de ellos quieren saber. Y tienen cuenta del tiempo, y conocieron algunos movimientos, así del solo como de la luna, que es causa que ellos tengan su cuenta al uso de cómo lo aprendieron de tener sus años, los cuales hacen de diez en diez meses. Y así entendí yo de ellos, que nombraban al año mari y al mes luna alespaquexe y al día auro. (Cieza de León, 2005, 259)

Así mismo agrega en otro pasaje de su texto: 
Luego que por el rey era entendido, mandaba llamar a otros de sus indios viejos, a los cuales mandaba que tuviesen cuidado de saber los cantares que aquellos tenían en la memoria y de ordenar otros de nuevo de lo que pasaba en el tiempo de su reinado, y que las cosas que se gastaban y lo que las provincias contribuían se asentase en los quipos para que se supiese lo que daban y contribuían muerto él y reinando su progenitor (Cieza de León, 2005, 323)

Analizando lo anterior, vemos que si es lícito hablar de una historia en los pueblos andinos en tanto registro y narración de hechos acontecidos en el pasado, y al no contar con una escritura alfabética propiamente dicha, generaron otras formas de registro tales como relatos orales y el sistema de quipos. En este sentido, Lame insistirá en que su relato histórico está inmerso en la memoria del pueblo, y registrado de forma ritual en la relación mística con la naturaleza y de forma textual en la escritura sobe piedra o los tejidos ancestrales:

el hombre para tallar la piedra y hacer jeroglíficos sobre ella, hacer caras de hombre, de animales y de aves, de oro con sus polluelos, cigarras, sapos, lagartijas, serpientes etc. Dichos escritos no los ha podido destruir la cólera de los siglos ni las edades han podido acabar con los fetiches de barro que prepararon amasada con la leche de árboles, mis antepasados (Lame, 1971,24)

En este punto es importante recordar la amplia cantidad de petroglifos existentes en las zonas de influencia de la lucha de Quintín Lame, por citar algunos ejemplos los existente en San Andrés de Pisimbalá (Cauca), Pitalito, San Agustín y San José de Isnos (Departamento del Huila) o Villagarzón (Putumayo), la mayoría de ellos sin estudiar a profundidad o sin descifrar desde la ciencia occidental, al igual que los Quillpus incas. 


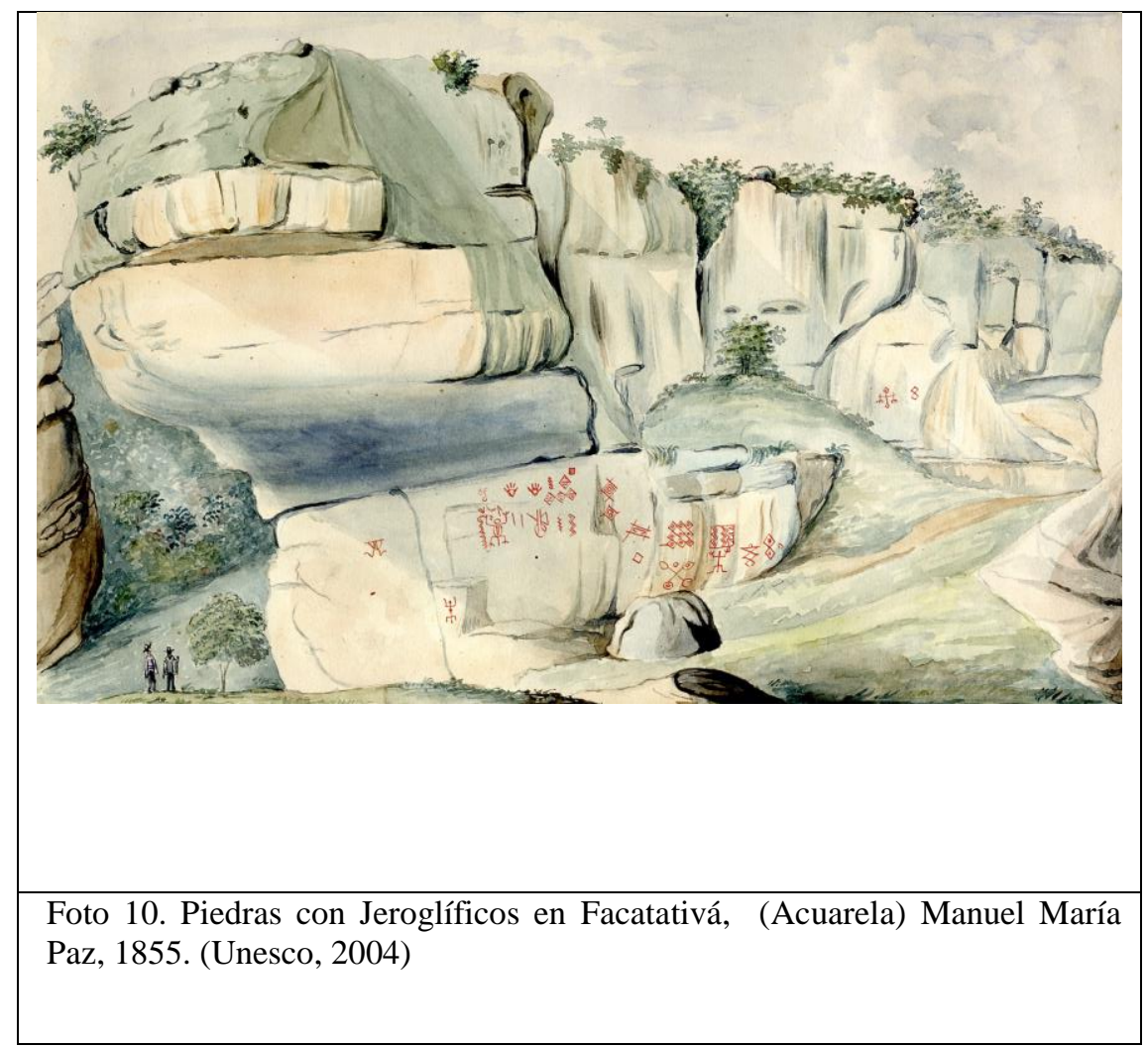

De hecho, parte del oprobio al que ha sido sometido el indígena por el dispositivo de control colonialista, es precisamente la falta de conciencia y conocimiento de dicha historia "pero hoy no se encuentra en Colombia una estatura de un Atahualpa, de un Bochica, como se encuentran en las demás Repúblicas hermanas; porque en Colombia ha sido y es la mansión del odio y la envidia contra el indígena" (Lame, 1971, 70)

Así mismo, observamos en el texto de Lame la confluencia entre elementos simbólicos y hechos históricos; alterna elementos de su propia lucha como el presidio en Popayán, con elementos míticos como la mención de Musaka o de Bochica, caciques legendarios como Juan Tama de la Estrella, y la fecha central de su relato, el 12 de Octubre de 1492, momento en el que empieza la resistencia contra el colonialismo y la defensa del territorio sagrado. En ese orden de ideas, más que un interés historiográfico de registro de acontecimientos a la usanza occidental, lo 
que existe es una selección de los elementos considerados necesarios para justificar y explicar la necesidad de reincorporarse a la lucha por la relación mística con el territorio, legitimando así el movimiento indígena usando la misma estructura discursiva que como era usada en los relatos históricos del Tahuantinsuyo para legitimar las luchas y conquistas de cada señor Inca.

Llega el acusador contra mi pedido por el Doctor Guillermo Valencia, Ignacio Muñoz y un sinnúmero de aristócratas enemigos de la imagen que tenía y tiene hasta hoy el indio Quintín Lame; imagen que me había acompañado en ese bosque de que hablé en el Capítulo1 y me acompaña hasta hoy; así donde se depura el pensamiento del indio para convertirse en idea, ideas que han sido murallas indestructibles por los elementos que tiene el enemigo del hombre que es el tiempo, cayeron las lluvias, soplaron los vientos, los ríos salieron de madre y dieron con ímpetu contra el edificio; el que había principiado por medio de la inteligencia infinita, del que hizo la armadura del primer hombre y la belleza de la primera mujer, hoy se encuentra el indiecito, dentro de esa muralla que yo mismo construí con mis lágrimas y sangre; la que hizo verter la envidia y el orgullo del español, el que llegó el 12 de Octubre de 1492 a hacerse rico a nuestro país y que nos trató y nos trata hasta hoy como bestias de carga. $(1971,17)$

En este orden de ideas, el libro de Quintín Lame muestra un manejo intercultural del mito y de la historia; los historiadores y los antropólogos habían planteado que el mito no es historia, no es verdad. En cambio, Quintín Lame maneja en su obra mito e historia sin que aparezcan como incompatibles, sin que se pueda decir que es un libro mitológico o que es un libro histórico, porque es ambas cosas. Lame entonces, circunscribe su relato histórico, su pensamiento y su lucha a una tradición en la cual confluyen la historia y el mito, de cuidado, relación espiritual y defensa del territorio contra el colonialismo, valiéndose del pensamiento 
andino que implica una autonomía, una tradición y una memoria colectiva capaz de asimilar y transformar los elementos que la sociedad occidental les ha ido imponiendo.

Este discurso se elabora siguiendo la línea discursiva de los relatos andinos, que consiste en la producción de narrativas simbólicas mediante la yuxtaposición de elementos míticos y simbólicos con el relato de hechos históricos. En este sentido la concepción de historia de Lame surge encadenando una serie de elementos religiosos, simbólicos y culturales. Esta legitimidad simbólica de Lame surge cuando la pacha le revela a Lame el conocimiento sagrado, haciéndolo "el pensador colombiano ante las ruinas de la prehistoria india":

Alcance a contemplar un árbol elevado, es decir, con una copa altanera orgullosa que coronaba las vírgenes selvas que me habían visto nacer tanto a mí, como a mis antepasados, antes y después del 12 de octubre de 1492, y este era un árbol llamado Cedro del Líbano, parecía que saludaba a las omnipotencias, una humana y otra divina, al pasar los cuatro vientos que tiene la tierra. Me llego un pensamiento que así de altas debían quedar colocadas mis ideas en la nación colombiana cuando yo bajara del monte al valle a defender mi raza indígena proscrita, perseguida, despreciada, robada, asesinada por los hombres no indígenas. (Lame 1971, 7).

Lo anterior lo podemos analizar como la presencia de elementos simbólicos emanados del pensamiento que ha revelado la Naturaleza a los pueblos indígenas, como una forma de resistencia epistémica a la mentalidad colonizadora de occidente. En este sentido, los discursos indígenas de resistencia al conquistador, parten de incorporar elementos simbólicos de su tradición, para conectar su discurso con la sabiduría de la pacha y su manifestación en la espiritualidad indígena 


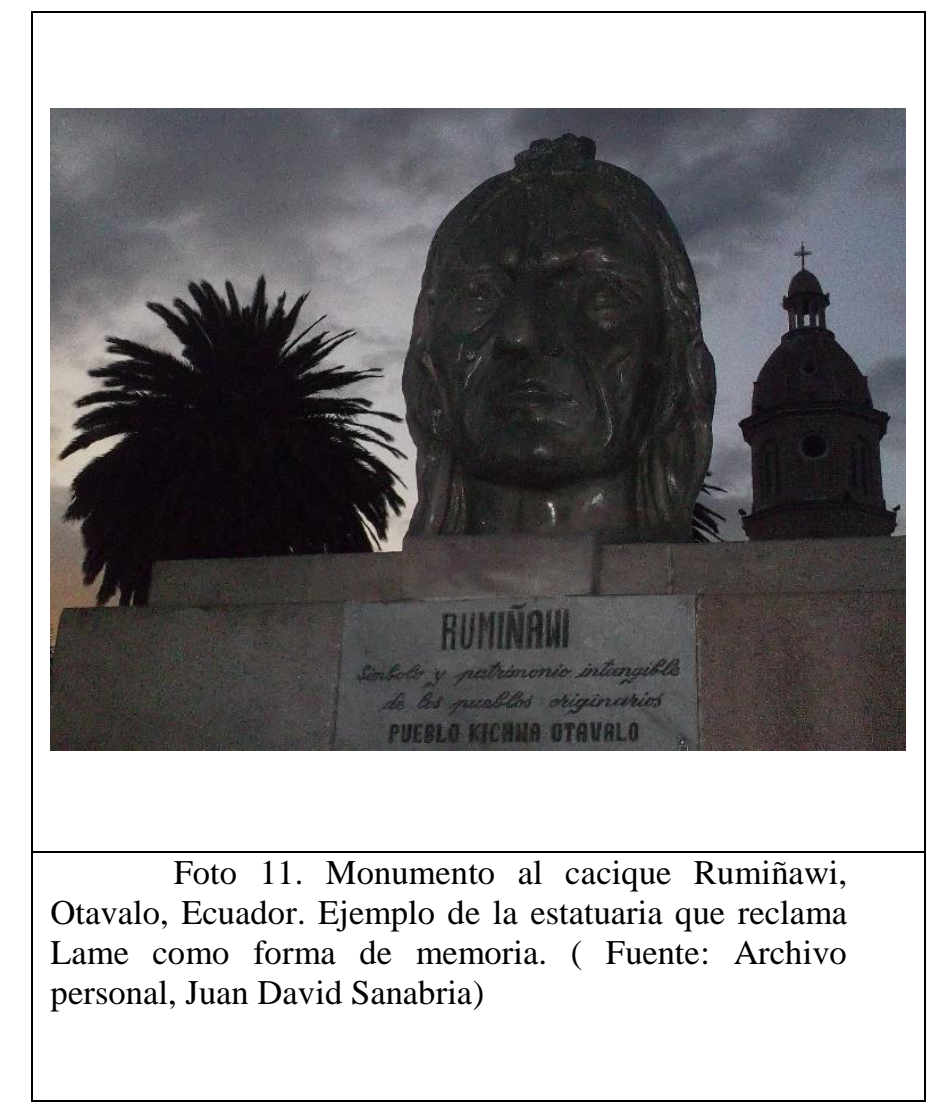

Lo anterior implica que la oposición categórica entre Mito e Historia, propia del pensamiento académico occidental, no es pertinente para comprender los procesos históricos y sociales de los pueblos amerindios. Así pues, en la episteme andina, el mito y la historia mantienen una convivencia que se justifica no solo en términos discursivos sino en imágenes simbólicas y cósmicas. Los hechos "sobrenaturales" que las imágenes míticas evocan dan sentido al relato, adquieren verosimilitud y explican aspectos profundos de una totalidad congruente consigo misma. Ejemplo de lo anterior es el relato de la victoria inca contra los chancas, dirigida por el Inca Pachacuti, referida por Franklin Pease en su artículo "el mito del inkarri y la visión de los vencidos" (1973). La narración sobre este acontecimiento hace hincapié en este soberano como un héroe solar capaz de mover las piedras y convertirlas en soldados. Así surgió la asociación del inca Pachacuti con un dios dinámico y bélico, 
fertilizador y amo de las piedras (Pease, 1973, 447). Este relato a su vez, con posterioridad, le dará una legitimidad mítica a la rebelión de Túpac Amaru, quien se reivindica como descendiente del Inca Pachacuti, como señala Tom Zuidema en su artículo "El juego de los ayllus y el Amaru" (Zuidema 1967, 49-50).

En los andes se sustenta entonces una concepción de la historia configurada gracias a la experiencia mítica del pasado. Así pues el relato histórico andino es la proyección del pasado sobre el futuro constituyéndose en una concepción central de la identidad del hombre andino. Esta lógica discursiva implicaría la reproducción del pasado en la memoria indígena para transformarla en una alternativa del presente. Alberto Flores, establece en su artículo "La utopía andina" (1982) que esta forma narrativa subyace a distintas expresiones de la memoria de los andes, tales como la tradición oral que se relaciona con las imágenes míticas del Pachacuti, la producción escrita de teoría indigenista, o la memoria oral y popular de movimientos sociales como el del Taqui Onqoy que pretendía la reposición de una sociedad igualitaria en el alto Perú del siglo XVI (Burga y Flores, 1982, 87-89).

Referencias a este pensamiento, anclado en la acción de las deidades andinas contra el colonialismo lo encontramos en las crónicas de Fray Pedro Simón quien señala como en la actual Antioquia en 1575 apareció en la actual Antioquia Zobze, una deidad indígena, a la que Simón llama demonio, vestido de negro, con el cabello largo y cubierto de una manta anudada al hombro. Era amigo de una hechicera vieja "quien se sentaba sobre él cuando hablaba a los indios" (Fray Pedro Simón, 1982, Vol. VI, 115). Se decía que Zobze comenzó a preparar la rebelión de los indios contra los españoles, mediante chamanes famosos que comenzaron a decirles a los indios que Zobze iba a consumir a todos los cristianos por medio de un diluvio. Al preguntarles los españoles sobre las razones de su agitación los indios 
respondieron “¡Pobres de vosotros, que dentro de tres días a lo más largo habéis de ser abogados con un gran diluvio!” (Fray Pedro Simón, 1982 tomo VI, 116). Otro ejemplo de lo anterior, de esa resistencia simbólica lo relata el mismo cronista quien refiere que en desarrollo de la guerra contra los Pijaos, un viejo Mohán (chaman) "al parecer de hasta noventa años" fue golpeado por los españoles "sin oírsele otra palabra de aflicción más que acalla, que quiere decir ¡ay de mí!” (Fray Pedro Simón, 1982, tomo VI 445). Murió aferrando de manera tenaz un pequeño ídolo de madera "de hasta una cuarta". De acuerdo con Simón, los mohanes utilizaban estos ídolos de madera, barro y piedra y tamaños variables para luchar contra los españoles en una suerte de guerra simbólica.

Esta tradición de los mohanes está relacionada a la tradición oral de coyaimas y natagaimas sobre las colinas de los Avechucos "el lugar donde vive el trueno" (Espinosa 2009, 42), lugares sagrados donde se referencia el obrar de seres mítico y héroes culturales. En las cuevas y en los manantiales de los ríos está congregada la potencia de los mohanes, que esperan su tiempo para volver a salir a la superficie no solo como seres humanos, sino también como paramos y nacimientos de agua (Oliveros 1996, 153). Esta versión de la huida de los mohanes al vientre de la tierra está presente en la tradición oral del Tolima:

Cuentan los ancianos que después de terminarse de hacer el mundo quienes existían estaban sin bautizar. Un día llegaron los misioneros bautizando a todos los seres existentes y causaron una gran conmoción. Asustados por tan extraña presencia algunos huyeron y quienes no lo hicieron fueron evangelizados. Unos corrieron y se ubicaron en los guácimos y chaparros, convirtiéndose en micos y monos; otros a las palmeras y arboles más altos, transformándose en loros y demás pájaros; pero algunos perezosos se quedaron en los matorrales volviéndose osos, perros, zorros, burros, vacas y otros animales cuadrúpedos. Los que se aposentaron en 
quebradas y ríos fueron los peces y demás animales acuáticos. De todos aquellos seres que huyeron los más inteligentes fueron los mohanes. Ellos construyeron túneles profundos con entradas principales en los cerros de Pacandé, San Pedro, Viana, Amacá, los Avechucos, Tuluní, Salto de Guaguarco, Molla de Fermín y Boquinche. Se instalaron allí en esas profundidades como espíritus, dueños de riquezas y habitantes de las aguas, con el encargo de hacerlas respetar para siempre (Comité regional indígena, 2000, 9).

Llama la atención, que la tumba de Manuel Quintín Lame está ubicada en el cerro de Monserrate, en las laderas de los Avechucos, pues al morir decidieron que era mejor llevarlo al antiguo cementerio indígena en tanto las autoridades eclesiásticas de Ortega, no aceptaron que Lame fuera enterrado en el cementerio cristiano (Espinoza 2009, 42). En este sentido la figura misma de Lame ha entrado a formar parte de la memoria simbólica indígena como elemento de la pacha que acompaña la cotidianidad y la resistencia indígena. Al ser enterrado en los Avechucos, Lame regresa al vientre de la pacha en un lugar sagrado, donde habitan los mohanes guardianes del conocimiento sagrado que ha sido revelado al propio Lame por la naturaleza divina. En ese orden de ideas, Lame mismo se convierte en una representación simbólica del conocimiento emanado de la pacha y vela por la difusión del mismo entre los indígenas:

el saber tradicional...ha acompañado las luchas indígenas desde siempre, ha servido para proteger a nuestros líderes, para mantener el equilibrio básico en nuestras comunidades y para sostener una relación especifica entre la naturaleza, el hombre, todos nuestros espíritus y los Dioses ancestrales, quienes velan para que los indígenas mantengamos nuestras propias leyes de origen (Concejo regional indígena, 2000, 22). 
Lo anterior esta referenciado en el propio obituario de Lame, publicado en el periódico $E l$ cronista de Ibagué, el 14 de octubre de 1967, que decía:

Hijo de un árbol y una piedra. Manuel Quintín Lame, otrora famoso líder y jefe de las comunidades indígenas, murió hace una semana; tenía 102 años...los indígenas los reverenciaban como a un dios; decía que era el hijo de un árbol y una piedra.

\subsection{Temporalidad y desarrollo histórico en Quintín Lame, a partir de la representación narrativa y estética del principio de metamorfosis de la vida (Pees Kupx) del pueblo} nasa.

Yule y Vitonas (2012) referencian el siguiente relato de la tradición oral nasa:

El ksa w "sueño" ayudó a ubicar las personas de manera que pudieran vivir sin hacerse daño entre ellos, al pasar el tiempo la tierra fue madurando porque al principio tenía mucha agua y la tierra era blanda pero con la ayuda de Kwetes sx (Peklu) "Hombre de piedra" quien convirtiendo algunas personas en piedra y sembrándolas en la tierra ella se volvió más maciza y dura. Antes de madurar la tierra personas como Kwetes sx no podían caminar porque la tierra era muy blandita y se hundían las personas, después de ubicar a las personas en su casa la abuela y el abuelo empezaron a hacer y crear las cosas que hacían falta a la casa o la tierra, pero al lado del abuelo y de la abuela andaba otra persona de rostro blanco era el Ecx, "Espíritu travieso que querían inventar o crear las cosas que los abuelos iban haciendo" ( Yule y Vitonas, 2012,160)

En este relato, se aprecia como antes de la acción creadora de los abuelos que actúan como divinidad organizadora del universo, fue necesario un proceso de maduración de cambio de la tierra misma. Lo anterior, implica que el principio de metamorfosis de la vida al que ya hicimos referencia, es un desarrollo que viene desde la pacha (Nasa Txiwe) misma. Todo lo que existe 
tiene su dinámica, su desarrollo, denominado maduración. Este proceso incesante de cambio, se fundamenta en los siguientes conceptos del pensamiento Nasa:

1- Nyafx "primero", palabra compuesta que se compone de n- que viene de en "Tiempo", espacio y yafx "vista", ojo. Es como el punto de partida, lo primero, la visión en el espacio y en el tiempo. Todo parte de un punto entendido como el tiempo primero, el principio. El pensamiento nasa explica lo anterior haciendo la analogía con el proceso de tejido, en tanto al tejer una mochila se parte de un ojo, de un punto y sobre esto se enrolla el hilo, se teje, y se forma un cuerpo. (Yule y Vitonas, 2012,160)

2- Pees Kupx: "La metamorfosis de la vida": En el mito de creación se dice que el mundo nasa es el regalo que desescama o muda, es como el mejor regalo realizado por los abuelos, que crearon y generaron la vida, el universo. Entonces como herencia de esta acción creadora se obtiene movimiento, estado, proceso y esto es U jya "ir, andar, salir" Pajya "llegar, entrar" y Sxwedya "volver, regresar". (Yule y Vitonas 2012,160)

3- Wala jya: “crecer" se entiende como el avanzar o madurar. Todos los seres parten del nyafx, punto primigenio de origen, pero para esto debemos ser sembrados, engendrados, por esto siembra "uhya" esta semánticamente relacionada con el acto sexual "Uhtxya" y con "Dhuya" "parir". Así pues, el desarrollo existencial a partir de la siembra de la vida que debe germinar y transformarse como hace la semilla, implica un hacer, entendido como producir, crear, y cambiar. (Yule y Vitonas, 2012, 160)

4- Yu "Agua": A nivel semántico se relaciona con movimiento, dinámica y proceso. Es el devenir (ir y venir). El agua es un elemento vital para dinamizar la vida, porque es energía. Yu se relaciona con u y "mujer" y con yu k "montaña" porque son seres que 
dinamizan y permiten el cambio, está relacionado con la movilidad. A nivel gramatical se constituye en marca indica cambio, es marca volitiva. (Yule y Vitonas, 2012)

En el relato del mito Yu luuck "hijo del agua" de creación de los nasanas "El ser humano" en familia se reafirma este concepto:

Unas estrellas no pudieron tener mujer por ser feos, unas mujeres hijas del Eekthe Wala "sabio del espacio" vivían solas, sin moverse en Nasa Txiwe, un día bajaron a conquistarlas y en este momento al esquivarse de A'we'sx “estrellas" ellas empezaron a moverse, al andar formaron ríos, riachuelos hasta llegar a un lago grande llamado mar y después se devolvieron ya fecundadas, a su lugar donde antes permanecían solas. Después parieron los Yu'luucx "hijos de las aguas”, así nacieron los nasas en familias. (Yule y Vitonas, 2012, 161).

En otros relatos míticos se habla del movimiento de la tierra y del sol y de los demás seres que crearon y reprodujeron la vida y el mundo nasa:

El sol no podía olvidarse de su primera mujer Uma y siempre venía a visitarla, pero por el lugar donde el pasaba se quemaba formándose desierto. Entonces viendo este acontecimiento la comunidad lo cogió y lo llevaron nuevamente a la otra tierra, allá hicieron un hueco metieron el sol y lo taponaron con una piedra grande para que no saliera y una vez en el hueco el padre sol empezó a forcejear hasta destapar el hueco y salió. Al pasar el tiempo volvió nuevamente a visitar la tierra, repitiendo otra vez la quema. A parte de su mujer e hijos analizando esta situación, la comunidad se reunió en pleno, cogieron al sol y lo amarraron, él quería quedarse con su mujer y lucho tanto hasta que su cuerpo se partió en dos pedazos logrando escapar un pedazo, esa parte del cuerpo 
se hundió hasta el centro de la tierra y la otra parte regreso a la tierra donde vive la segunda mujer A’te “Luna..." (Yule y Vitonas, 2012, 161).

En este relato se da cuenta de una época en que la tierra se acercó al sol, considerada por la tradición oral nasa como la visita del sol a la tierra. A partir de este relato, podemos ver como el constante movimiento del sol y la tierra, es decir de los seres del Nasa Tixwe genera la dinámica de la vida. La metamorfosis de la vida es pues un principio de cambio y desarrollo que agrupa todos los elementos de la realidad.

De forma ritual, el pueblo Nasa hace rememoración de ese movimiento vital del universo, mediante el significado profundo de la actividad del tejido, pues al coger y girar el huso de lana para hilar la lana, se rememora este movimiento, y genera una distribución de los hilos, que simbolizan el conjunto de los acontecimientos ocurridos al interior de Nasa Kixwe. Así pues, toda maduración o desarrollo desde la sabiduría nasa es expresada en sus tejidos mediante una representación lineal. Cada acción se representa mediante formas que pueden ser lineales, circulares, elípticas, o espirales. Estas acciones que implican el conjunto de la existencia en Nasa Kiwe, dependen del movimiento o del proceso de desarrollo análogo a la germinación de la semilla o la metamorfosis de la naturaleza (Yule y Vitonas, 2012, 162)

1. Lo lineal: Es el movimiento de la mirada, que puede ser horizontal o vertical pero de igual manera es el desplazamiento de la nasa y los seres vivos de la Naturaleza. (Yule y Vitonas, 2012,162)

2. Lo circular: Son las actividades cotidianas como comer, trabajar, dormir, prácticas de purificar; son acontecimientos ubicados en un hoy, en un antes y en un después, es decir son las rutinas tanto del ser humano como de la naturaleza, tales como los fenómenos biológicos recurrentes como las épocas de lluvia o las subiendas de pescado. También aquí se simboliza 
el proceso del cambio biológico como es el Pees Kupx, el fecundar, nacer, crecer, reproducir y el volver nuevamente a su estado de origen. Las épocas de preparación del terreno, de siembra, de cosecha y de almacenamiento. (Yule y Vitonas,2012, 162)

3. Lo elíptico: Toda maduración en su acción, en su espacio y en su tiempo tiene sus altibajos. Por ejemplo hay caminos que según la topografía del terreno pueden ser horizontales, otros van en forma de zigzag, otros tienen muchas vueltas (curvas), de acuerdo a estas líneas trazadas nos movemos. A veces encontramos obstáculos según la topografía, a veces nos podemos tropezar, podemos tener conflicto con otros seres como el ataque de un animal. Así mismo, en el proceso de cambio biológico que tiende a la maduración una lesión o una enfermedad pueden implicar un retroceso natural dicho proceso. El nasa cree que constantemente debe estar prevenido para evitar los obstáculos, que impiden andar bien, por eso debe refrescar y purificar constantemente el espacio en que se mueve y alegrar constantemente a los espíritus de la naturaleza. En este orden de ideas, el movimiento elíptico integra lo lineal y lo circular. Es avanzar, devolverse y repetir lo mismo y avanzar. Forma una línea similar a como se hila la lana, con el huso se entorcha el hilo en esta forma, similar a la de un resorte: Inicia en un punto, avanza, vuelve y continúa en un ir y venir, formando y trastocando puntos a nivel interno, estos puntos marcan el crecimiento, la maduración que representa el espiral.(Yule y Vitonas,2012,162)

4. El espiral: Entonces la línea espiral se forma al enrollar, desenrollar hilos para entretejer y formar cuerpos a partir de un punto. Es la representación del crecer, el madurar. Por eso n podemos tener solo la mirada o el pensamiento de que el desarrollo sea totalmente lineal, ni totalmente circular. El desarrollo y la dinámica de la vida se mueve y crece en un ir y venir. El devenir, condicionado e integrado por lo lineal, lo circular y lo elíptico. Inicia a enrollarse 
desde un punto, avanza y vuelve y continúa, en un ir y venir, formando puntos de movimiento interno; estos puntos marcan el crecimiento, la maduración. (Yule y Vitonas, 2012,162.)

Lo anterior se interpreta desde el mismo pensamiento nasa de la siguiente manera:

“Ksaw es el soñar despierto y dormidos, es nuestra utopía, pero que al dinamizarlo integra lo lineal, lo elíptico, lo circular, los cuales nos permiten volver real nuestros sueños de acuerdo al momento, a las necesidades y a las circunstancias de la vida en que nos movemos. Esto equivale al Plan de Vida" (Yule y Vitonas, 2012, 163).

Este crecimiento y maduración, con su proceso espiral de movimientos y cambios internos, se refleja en una temporalidad y espacialidad expresada de la siguiente manera:

1- Acxtey: "hoy" El hoy entendido como el tiempo presente, es el momento real, ubicado como ayte "aquí". ( Yule y vitonas, 2012, 163)

2- Yecteywe sx: "de los de adelante" Es el tiempo de los antepasados, de los mayores que trazaron un camino, puede ser real o irreal; puede existir un delante real cuando me consta, relativo cuando lo confirmo o por otras versiones. Es el tiempo pasado y como espacio de adelante, es el espacio de los mayores, es la historia. Lo que está delante lo puedo ver, por eso es real. ”( Yule y Vitonas, 2012, 163)

3- E steywe sx: "los de atrás": Es el espacio de atrás, en nuestro cuerpo es la espalda, para yo ver lo que está detrás tengo que desdoblare, es inclinar la mirada desdoblando el rostro de lo irreal, lo que se dice con duda, lo relativo. Por eso a un niño la madre nasa lo carga sobre su espalda, porque no se sabe si cumpla su ciclo natural. "( Yule y Vitonas, 2012, 163) 
4- Walaiya: Crecer. Construir la casa en épocas y espacio: En el tiempo de la tierra maduro en escala, es lo que llamamos época, está relacionado con A kafx "hueco en las estrellas", luna. Es el espacio dejado en cada fase de la luna entendido como el momento y la época un espacio. ( Yule y Vitonas, 2012, 163) Entonces como Nasa Tiwe "territorio de los seres" se concibe como yat "casa", se construyó de manera análoga a una casa. Entonces parte de una base que está concretada en el mito de origen. Entonces podemos decir que al crecer, madurar en los seres se da en un tiempo llamado épocas y en un espacio al igual que Nasa Kiwe, al igual como se creó el territorio, el universo como casa y semilla. Este desarrollo se da en las siguientes walaiyas como lo reseñan Yule y Vitonas $(2012,164)$

- La época y el espacio de Eekthe (trueno). El gran sabio del espacio. La primera casa

- La época y el espacio de Uma (Agua) esposa del sol, con sus hijas mujeres.

- La época y el espacio de Tay (Sol).

- La época y el espacio de A Te (Luna), segunda esposa de Tay con sus hijos hombres.

- La época y el espacio de Tafxi (Aire). Es el silbido. Se relaciona con Wehxa uus (Corazón del viento).

- La época y el espacio de Kabaya (compromiso de relación, unión en parejas).Donde nacen los Nasa, las plantas, los animales y se organizan los indígenas como Nasanas o Nasawe xk (seres humanos en familia).

- La época de Kwetwe sx ( Ser de piedra). Fue el cacique de piedra que vivió mil años e hizo posible que la tierra se volviera más maciza y dura.

- La época y el espacio de Khabuwe sx, las autoridades. 
- La época y el espacio de Txiwe nwe wya (Clamor de la tierra). Es el momento de la defensa del Territorio que se da a partir de la colonización española.

- La época y el espacio de Juan Tama, Quilo y Sicus (Caciques y líderes indígenas de la época colonial), quienes lucharon y defendieron el territorio bajo acuerdos y mandatos escritos).

- La época y el espacio de Quintín Lame, pensador indígena y terrajero quien "hizo una lucha con puntos programáticos de abolición del terraje, de recuperación de tierras, de rescatar la autoridad, las leyes y la cultura, que sirvió de base para la creación del CRIC" (Yule y Vitonas, 2012, 164).

- La época y el espacio del CRIC, (Consejo Regional Indígena del Cauca), estructura organizativa para la lucha reivindicativa y la administración de territorios indígenas desde 1971.

- La época y el espacio de Txiwe Tudya "amarrar la tierra", es la época de volver a pensar "desde el centro de la tierra" para garantizar la identidad cultural y la autonomía. 


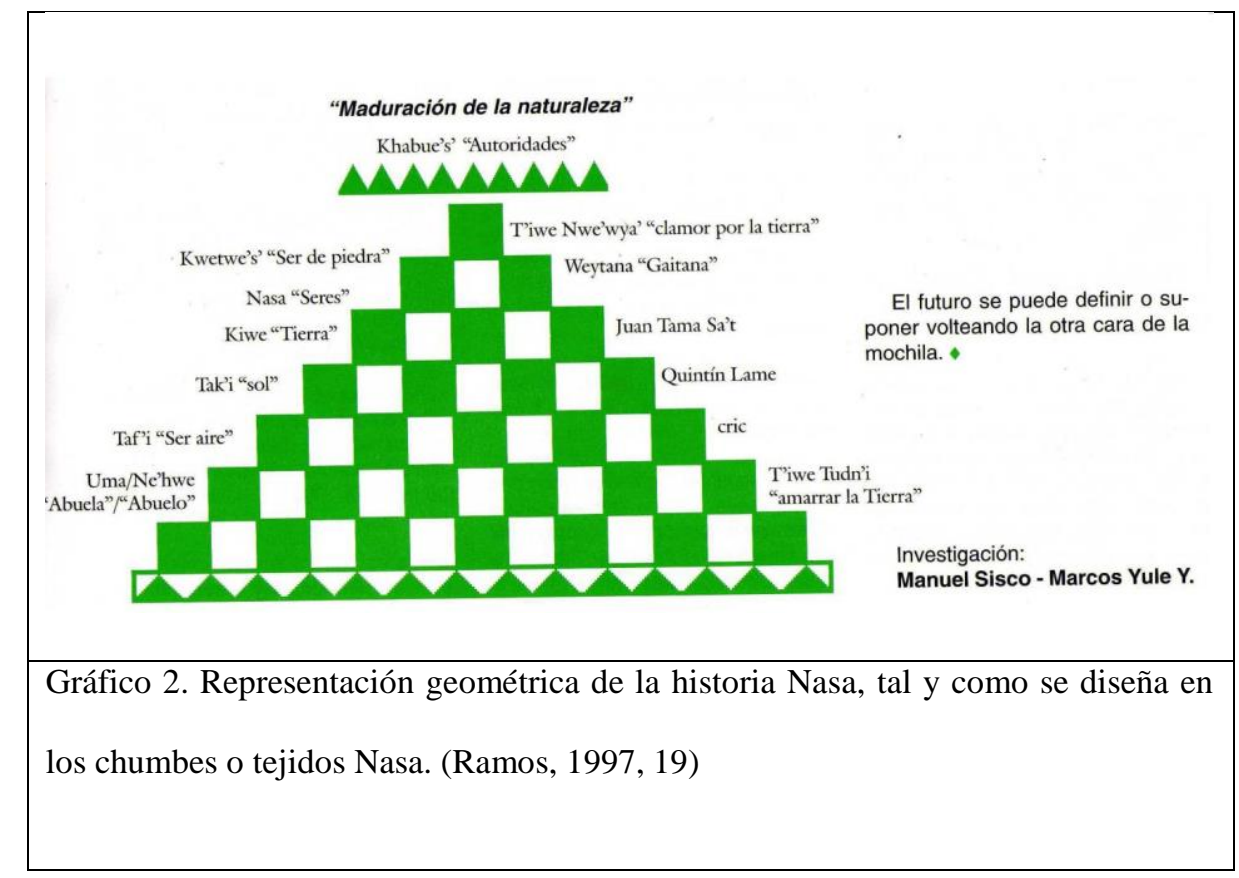

\subsection{La historia en el texto de Manuel Quintín Lame}

Es posible afirmar entonces que la historia es en Lame un relato simbólico en el que el pasado se proyecta hacia el presente a través de una lógica discursiva sustentada en el pensamiento andino.

Ahora bien, una vez para poder explicitar las categorías presentes y las implicaciones filosóficas de lo anterior, es necesario dar paso al siguiente punto metodológico de la investigación, a saber, cuestionar la concepción de historia de Lame a partir de los interrogantes de la Filosofía de la historia occidental. Se estableció en el segundo capítulo, que Lo anterior puede ampliarse, afirmando la filosofía crítica de la historia tiene como problemas de investigación sse ocupa de los conceptos por los medio de los cuáles se entiende, o puede entenderse, la realidad histórica, así como de los conceptos básicos usados en la ciencia histórica o la historiografía, lo que conlleva a preguntas como ¿Qué tipo de realidad es la realidad histórica? ¿En qué se distingue la realidad histórica de la realidad 
natural? O ¿Cuál es la naturaleza de los hechos históricos? Ahora bien, desde una perspectiva epistemológica, es decir a la relación sujeto cognoscente - objeto conocido, la filosofía crítica de la historia está llamada a pronunciarse sobre aspectos como las siguientes: ¿Es el conocimiento histórico un conocimiento de leyes? ¿Es un conocimiento inmediato fundado en alguna forma de experiencia humana? ¿Es el material histórico fundamentalmente conceptualizable o simplemente intuible? ¿Son las leyes históricas distintas o no de las leyes naturales? (Ferrater, 2004, 1652).

En este orden de ideas, vemos que la importancia que le da Lame a la Naturaleza como un todo que incluye al ser humano, de forma análoga al concepto quechua de Pacha, tendrá varías implicaciones:

las vírgenes selvas que me habían visto nacer tanto a mí, como a mis antepasados, antes y después del 12 de octubre de 1492, y este era un árbol llamado Cedro del Líbano, parecía que saludaba a las omnipotencias, una humana y otra divina, al pasar los cuatro vientos que tiene la tierra ( Lame, 1971, 7).

Vemos, que esa integralidad de la Pacha, que engloba las realidades natural y humana, no permite deslindar lo humano de lo natural o lo territorial, y por ende, no sería posible deslindar lo natural de lo histórico. Es entonces la historia un relato de la memoria del ser humano en la Naturaleza, del ser humano y su relación en y con la Pacha. En esa medida es que la historia solo es cognoscible a partir del conocimiento revelado por la Naturaleza, quien en tanto fuente de todo conocimiento asume el rol de generadora y guardiana del conocimiento histórico, que revela de forma espiritual a los indígenas para que puedan narrar, conocer y hacer vivo el recuerdo. Es pues un recuerdo sacramentalizado en tanto se proyecta 
en el presente gracias a la intervención espiritual de la Naturaleza, para servir de guía ante los problemas contemporáneos de las comunidades indígenas.

Por su parte, la filosofía especulativa de la historia, atañe a problemas como la cuestión de los factores causales y en particular, los factores causales últimos de la historia. Así mismo, aparece aquí la cuestión sobre el sentido último de la historia, que a su vez, implicaría un cuestionarse sobre problemáticas como la existencia de los llamados "factores determinantes de la historia", sean estos materiales como por ejemplo la lucha de clases o la relación con las condiciones geográficas, o ideales, tales como el Espíritu o la Voluntad. (Ferrater, 2004, 1652)

Esta presencia espiritual de la Naturaleza, implica a su vez, un accionar de índole mítica de la misma, es decir una estructura narrativa que mediante imágenes simbólicas como metáforas o alegorías da cuenta de la presencia divina encarnada en la Naturaleza y su conocimiento a lo largo de la historia. Esto explique no solo la pervivencia sino la centralidad de los arquetipos míticos presentes en la narración histórica de Lame.

Es decir, la realidad trascendente de la historia o factor determinante de la misma, será, el desarrollo de la Pacha misma en tanto realidad histórica y temporal que contiene y genera la dimensión misma de lo humano, que se desarrolla siguiendo el esquema de pensamiento Nasa de La metamorfosis de la vida, a partir de la relación espiritual del indígena con la Pacha, que tiene diversos walaiyas o momentos, que van desde la creación misma de la pacha y por esta del ser humano, la organización del universo por los dioses y la vida del indígena acorde a las leyes emanadas de la misma naturaleza, fragmentadas por la colonización española y su subsecuente cambio en la realidad territorial del indígena. Es en este sentido, que el centro de la narración es el 12 de Octubre de 1492, pues a partir de él se puede proyectar la ruptura de la vida indígena 
sustentada en toda la dimensión simbólica de la Naturaleza, como la imperiosa necesidad de asumir los problemas contemporáneos a Lame desde la reivindicación del pensamiento propio, que siguiendo los citados casos de resistencia epistémica, se asume como elemento subversivo, lo que permite que Lame pase a ser parte de la memoria indígena como guardián y maestro el conocimiento indígena y se integre así mismo al espíritu de la pacha ene se sentido, ya sea al ser enterrado en el sitio sagrado de los Mohanes Pijaos, o ser representado en los chumbes Nasa como una walaiya misma de la relación entre Nasa y Nasa Kiwe.

Interpretando la historia como un relato, partiendo de la acepción original del texto, el punto de partida de Lame es la denuncia, denuncia de sus sufrimientos y los de su pueblo. Al describir dichos episodios en los que el indígena se configura como víctima, los sufrimientos de Lame están narrados estableciendo una analogía a los de figuras bíblicas como Jesús, Moisés y Noé de forma acorde a la concepción religiosa del autor, que ya ha sido descrita en el segundo capítulo del presente trabajo.

Todos mis actos quieren borrarlos en forma que los Judíos pidieron al gobernador Romano que

borrara o quitara el inri de la Cruz, etc., y los Césares quisieron ocultar el misterio de la Pascua,

es decir, de la Resurrección del que había muerto en la Cruz. (Lame, 1971, 57).

Ahora bien, estos sufrimientos tienen un origen histórico concreto, que es la llegada de los españoles en 1492, momento de la gran fractura que dio comienzo a la historia de injusticias e iniquidades contra el hombre indígena.

A partir de allí, el recuerdo sobre las atrocidades de la conquista, pasa a ser un elemento de problematización de la historia latinoamericana, pues ante la exposición de la injusticia del 
colonialismo se cuestiona la validez de los derechos de los conquistadores y sus descendientes. En oposición al momento histórico del colonialismo, se resalta la grandeza y el poderío de las antiguas culturas, dioses y pueblos de América indígena. Persistentemente se niega a llamar a nuestro continente por el nombre europeo y lo sustituye por el nombre de Guananí, primera tierra americana pisada por los europeos. En este momento su discurso se proyecta hacia el futuro que verá el resurgir de los pueblos indígenas, triunfantes y autónomos. En este punto, se señala con cierta recurrencia "la ley de la compensación" la cual restituirá al pueblo indio sus tierras, su autonomía, su antiguo poderío, en detrimento del blanco usurpador.

Así nacerá mañana un concierto de indígenas de esos descendientes legítimamente de nuestra tierra Guananí, descendientes de esas tribus odiadas, perseguidas del hombre no indígena; pero la ley de la compensación existe señores porque ella misma es la justicia vengadora. (Lame,1971)

Una columna formará un puñado de indígenas el día de mañana para reivindicar sus derechos, como reivindicó Dios la humanidad, es decir, la rescató de la tiranía del demonio; así rescatará La raza indígena sus derechos en Colombia y quedará el blanco de arrendatario del indígena... (Lame, 1971)

En este sentido, discursivamente Lame sitúa el sufrimiento de sus ancestros y hermanos indígenas así como su propia lucha dentro de un contexto común aferrándose a la memoria mientras esta titilaba en un momento de peligro, el peligro de ser borrada, anulada. Lame logró articular el pasado históricamente, en un relato articulado desde imágenes del pasado a través de la yuxtaposición de marcos temporales, la omisión de explicaciones causales y la estructuración de la narración de una forma no lineal. 
Lo anterior no implica la ausencia de un sentido de causalidad, pues aunque la concatenación de hechos históricos con relaciones causales no está representadas necesariamente en la narración misma, hacen parte de la memoria oral. Así pues, la forma en la que se recuerdan y organizan los hechos dentro de un marco temporal está estructurada en torno al espacio físico y ritual y no a la temporalidad cronológica. Dicha estructuración discursiva implica una dimensión ritual de la historia que se basa en los contrastes y las contradicciones entre el pasado tal como fue experimentado y la estructura del mundo presente.

La historia aparece en Quintín Lame como "una narración simbólica que conjuga elementos míticos del pensamiento andino, sustentado en el concepto de Pacha, con el relato de hechos históricos. En esa medida es la descripción de las distintas Walaiyas (épocas del desarrollo de Nasa Kiwe según el pensamiento Nasa) orientado en una lógica narrativa que proyecta los acontecimientos del tiempo de los mayores y los ancestros ( yecteywe) sobre el momento presente del autor ( acxtey); para a partir de la misma formular un plan de vida conjunto para el pueblo Nasa que, reivindicando la autoridad espiritual de los caciques míticos permita plantear un proyecto de vida conjunto para los indígenas colombianos, sustentado en la reapropiación de la autonomía territorial bajo los preceptos de gobierno propio indígena. Este plan de vida, tiene una perspectiva de sustentación en la religiosidad andina, que partiendo de la visión andina de Dios como creador y organizador del mundo, y de la visión de Jesucristo como liberador de los oprimidos del mundo, plantea asumir la liberación del territorio del dominio colonialista para experimentar en esta lucha la reimposición del orden del Nasa Kiwe emanada de la divinidad, y como concreción del proyecto de la esperanza cristiana para los explotados." 
La historia en el pensamiento de Lame expresa el orden y el desorden según una secuencia desde los soberanos antiguos hasta el cacique Juan Tama. Tal alternancia se verificaría, por una parte, en la disposición de elementos sociales y materiales que expresarían la unidad espiritual con el territorio y la producción cultural.

En el transcurrir del tiempo, Lame mismo es el momento en el que se desencadenan las fuerzas de inversión constituyéndose un nuevo orden. Sin embargo, teniendo en cuenta que los cambios se dan en analogía respecto del futuro y el pasado, resulta en que el propio Lame representa un momento limítrofe. El liderazgo espiritual y político de Lame se asocia entonces con un nuevo período, una inversión que anuncia "el tiempo de los indios".

El pensamiento de Lame es un proyecto intelectual de la esperanza frente al peligro. Es comprensible que desde un punto de vista filosófico este pensamiento sobre el futuro y sobre el tiempo pueda, a su modo, ayudar a una teoría escatológica.

Existe una separación entre realidad como es y como debiera ser. En otras palabras, la comunicación espiritual con la Pacha se entiende como una palabra de promesa en la cual "la revelación" y "la enseñanza" de esta es preanuncio del futuro.

El llamado de Lame a la acción, es decir, su enseñanza de acuerdo a los preceptos de la sabiduría de la Pacha, procede como una autorrevelación de la Naturaleza de forma indirecta, a través de las gestas históricas de los indígenas por el territorio.

La revelación no está compuesta por hechos desnudos, sino por acontecimientos que reciben significado solo en relación con la episteme andina. Los acontecimientos de la historia hablan el lenguaje de la Naturaleza, pero este lenguaje, solo se puede oír en contexto 
y en el ámbito de la tradición ancestral, la episteme andina y la espera por una restitución del orden cósmico en medio de la cual transcurre la historia.

La historia es entonces una narrativa simbólica de la memoria, entendiendo por esta última, no la tendencia a ver el pasado bajo la óptica endulzada de la idealización, sino como una manera de disociarse de los hechos como son, en nombre de contenidos subversivos y peligrosos para el statuo quo. En el marco de la episteme andina, Lame renueva la memoria ancestral nasa, y siguiendo los preceptos de la pacha hace memoria de la dimensión simbólica del territorio que posibilita una organización social acorde a los usos indígenas. En ese sentido, Lame encarna en el más alto grado esa memoria simbólica y liberadora.

Lo anterior, implica un esfuerzo por expresar la sabiduría ancestral en relación con la época moderna como figura simbólica que detone la acción política. Es entonces un simbolismo memorial y narrativo de la memoria, cuyo dato central está constituido por el recuerdo narrativo de la relación espiritual con el territorio.

Los indígenas no son en primer lugar una comunidad interpretativa-argumentativa, sino más bien una comunidad memorativa-narrativa dominada por una voluntad práctica.

La narración mantiene presentes a las generaciones pasadas evitando olvidar o desechar los dolores del pasado, de los ancestros que sufrieron la conquista y las violencias del colonialismo, trayéndolos a colación en la reivindicación del pensamiento ancestral y en la lucha presente por la liberación indígena; trayendo en el bienestar de los nietos el remedio al sufrimiento de los abuelos, víctimas del ayer, en tanto son miembros partícipes de la comunidad espiritual indígena sustentada en la relación con la naturaleza.

\subsection{Las historias de los vencidos en América Latina}


Una vez establecidas las características del relato de la historia en Quintín Lame, es momento de pasar a analizar sus implicaciones. Evidentemente, el texto de Lame no aparece como un único testimonio de la voz del indígena bajo el colonialismo. Una revisión de lo que podríamos denominar como literatura indígena nos permite ver como aparecen filtrados en el corpus de los textos coloniales, escritores nativos que tomaron prestada la herramienta de la escritura alfabética para narrar la versión propia de los sucesos, para contar lo que, en términos de Miguel León-Portilla, sería "la visión de los vencidos" (1989), imagen esta con la que titula una selección de textos escritos por indígenas mexicanos durante el período de la Colonia. En ellos, la historia de la conquista es narrada desde la perspectiva del dominado; es decir, que se puede entender "la historia escrita, simultáneamente, (como) un instrumento de dominación colonial y [como] un vehículo de empoderamiento insubordinado que somete a la memoria social" (Gnecco $96,180)$.

\subsubsection{El relato de Guamán Poma de Ayala como historia de los vencidos}

En este orden de ideas, es importante reseñar la publicación de los Comentarios reales del Inca Garcilaso de la Vega y Nueva crónica y buen gobierno de Felipe Guamán Poma de Ayala, como la aparición en el contexto colonial andino la voz del indígena, y estos textos tendrán un rol análogo al de los textos de la "visión de los vencidos".

Guamán Poma emplea la escritura y la pintura para comunicar a su lector principal, el rey y a los demás lectores cristianos, toda la historia del Perú, toda vez que arremete contra los abusos de los conquistadores. Guamán Poma describe con sus palabras y dibujos no sólo el pasado andino sino también el lado amargo de la conquista de Perú. En este texto se representa tanto el conflicto entre el indígena y el español como el que surge entre los mismos conquistadores. Con todo, es importante recordar que él se dirige al rey Felipe III 
porque acepta como irremediable la presencia de los colonizadores y quiere sugerir un nuevo plan para su pueblo. En ningún momento critica directamente la autoridad del rey.

En las particulares de la escritura, se observa que si bien este autor utiliza algunas convenciones de la escritura occidental no respeta la historiografía de Occidente, pues por ejemplo, no se rige por la cronología europea. De hecho parecería que a Guamán Poma le resultara difícil expresar todo lo que quiere decir de dos culturas tan distintas utilizando una sola metodología. Para resolver lo anterior, aspecto difícil en tanto la versión europea de la conquista del Tahuantinsuyo no correspondía a la visión andina de dichos sucesos, Guamán Poma subvierte la historia de la conquista, aunque también advierte la dificultad de escribir la historia de un pueblo sin escritura (Adorno, 1982, 113). No obstante, el hecho de que ha recurrido a la pintura y otras formas de representación para comunicar todo lo que quería decir, apunta a que incluso la escritura no es un instrumento adecuado para expresar la visión andina del mundo.

Poma de Ayala subvierte el discurso colonial desde el inicio, restando autoridad a los cronistas y cuestionando la historia oficial del Perú, al denominar su obra primer nueva crónica. Es así como llega a cuestionar todo lo escrito por los cronistas sobre los hechos acontecidos en el Perú junto con la imagen que construyeron del indígena. La estrategia de insertar al indígena dentro de la narrativa señala que el escritor relata aquí su historia y no la del colonizador. Este recurso demuestra que el indígena es el dueño de sus opiniones que se puede expresar solamente a través de su lengua nativa. Es decir las acciones que le corresponden al español se expresan en castellano pero las reacciones a las mismas son indígenas y se expresan en quechua. Ejemplo de lo anterior es el momento en que el autor 
comenta el trato español al Inca Atahualpa, fragmento en el que el llanto de los indios aparece en quechua:

“Como le prendieron y estando preso Atahualpa Inga, estando preso le robaron toda su hacienda don Francisco Pizarro y don Diego de Almagro y todos los demás soldados y españoles y lo tomaron toda la riqueza del templo del sol...hasta quitarle su mujer legítima...hubo grandes llantos en la ciudad de los indios, cantaban de esta suerte: array araui array araui sapra aucuchado coya atihuanchic llazauanchicma coya suella uanoson amatac acuyraqueca cachundo paracinam uequi payllamanta urmancam coya hinatachha." (Poma de Ayala, 282)

La incorporación del quechua como idioma de la narrativa, sirve para acentuar la diferencia tanto cultural como lingüística, genera un empoderamiento del indígena frente al texto en tanto enajena al lector no quechua hablante y remarca uno de los ejes del texto, la comparación crítica entre conquistadores e indios. En este sentido el autor resalta que el indígena realmente no puede aprender nada de los colonizadores ya que estos no tienen nada bueno que enseñar:

"vez aquí en toda la ley cristiana no he hallado que sean tan codiciosos en oro ni plata los indios, ni he hallado quien deba cien pesos, ni mentiroso, ni jugador ni perezoso, ni puta, ni puto, ni quitarse entre ellos, que vosotros lo tenéis todo inobedientes a vuestro padre y madre y prelado y rey; y si negáis a pie juntillo, todo lo tenéis y lo enseñáis a los pobres de los indios, decís, cuando desolláis entre vosotros y mucho más a los indios pobres, decís que habéis de restituir, no veo que los restituía en vida ni en muerte" (Pg. 265) 
La imagen que sigue del indígena en el texto de Poma de Ayala es la de un ser dinámico y fuerte que no ha sido dominado totalmente por la conquista, y sobre todo que no ha perdido ni su memoria ni su voz. El acto de recuperar la memoria histórica es un paso notable en el proyecto de hacer valer su identidad individual y colectiva. Guaman Poma también se aprovecha de esta oportunidad para sugerir la manera en la que el rey español podría rectificar el sistema administrativo del Perú y cambiarlo para que incorporara el sistema andino, en el que participaría activamente el indio. De esta manera, él sería capaz de gobernar su propia tierra, como lo era antes de que vinieran los españoles. Para fortalecer este punto este autor describe cómo vivían los nativos bajo la ley indígena:

"De como los indios usaban de misericordia, y por ello todos comían en plaza pública, porque se allegasen pobres peregrinos, extranjeros, huérfanos, enfermos, y los que no tenían que comer; todos comían bien y las sobras se las llevaban a los pobres. Ninguna nación ha tenido esta costumbre y obra de misericordia en todo el mundo como los indios de este reino santa cosa" (pg. 49, tomo I)

Más adelante se describe al indígena como un ser piadoso, bueno e inteligente:

"indios de este reino como españoles de castilla saben y aprenden de todos los oficios, artificios, beneficios, los cuales son grandes cantores y músicos de canto, de órgano y llano... son escribanos de cabildo y de público, y nombrado, y teniente de corregidor, alcalde mayor...sabe jugar con armas, espadas y montante, partesana; juegan todo juego como español;...sabe latín y romance; si le aprobara se ordenara sacerdote de la Santa madre iglesia" (Pg. 221, 822, 836, tomo II)

Es importante señalar en este sentido que en la Nueva Crónica, en la última parte el autor dirige directamente al rey su lamento por un mundo "al revés". Con esto se refiere al hecho 
de que en esta época los barbaros (los europeos) se portan como líderes y conquistadores de los civilizados (los andinos), ahora concebidos como los de abajo. La angustia de Guamán Poma comunica el sentimiento del pueblo subordinado y reprimido en su propia tierra, dando cuenta de la resistencia del sujeto colonial durante el periodo de subordinación desde la perspectiva "del otro".

\subsection{La historia en Quintín Lame como historia de los vencidos}

En su texto, Lame condenso la historia de sus antepasados, a través de una serie de imágenes narrativas y simbólicas que denuncian la conquista e iluminan el presente de opresión de los indígenas. En el texto el año de 1492 se señala como la fecha icónica de la era de dominación para los indígenas, mediante el deseo español de “comer sin trabajar" y su práctica colonizadora mediante la expropiación de las riquezas materiales y espirituales de los nativos. En este orden de ideas Lame denuncia el lado oscuro de la civilización occidental: el despojo territorial, el abuso, la injusticia y el sufrimiento.

La rememoración de la historia indígena sobre la cual está construido el texto de Lame nutrió la memoria moral y la conciencia histórica de los indígenas colombianos, en una narrativa que combina la necesidad de restauración del orden cósmico de la pacha, con la denuncia de las relaciones de poder que alteraron el mismo y que fueron impuestas de manera violenta por los españoles.

Este discurso histórico andino, debe entenderse como una historia de los vencidos, utilizando el concepto de Foucault. En este sentido, Sánchez Parga (1988) afirma que es un relato surge del hecho de que a partir de la conquista la identidad sociocultural de los grupos 
andinos se forjó en la resistencia apareciendo sobre determinada por una profunda y permanente confrontación con el otro (Sánchez Parga 1988, 130)

Así pues, el presente se caracteriza porque reúne los procesos del pasado y el futuro. Desde atrás, el futuro augura la venida de un nuevo liderazgo emanado del conocimiento sagrado de la Pacha que de manera pendular reorganizará las relaciones prevalecientes retornando a un orden donde prevalezcan las categorías epistémicas de los oprimidos sobre las de los opresores. En este sentido, el cambio que se dará con relación al presente, representa la ausencia de sujeción y explotación étnica.

Mónica Espinoza ( 2009, 59), señala como durante el siglo XVIII, los resguardos del macizo colombiano estaban integrados no por comunidades originarias del sitio, sino por núcleos de poblaciones desplazadas y reasentadas, a veces de composición cultural diversa. Desde luego, la influencia de las prácticas de poder y de los sistemas de autoridad prehispánica fue central en la consolidación misma de los resguardos indígenas, y en su estabilización y proyección en el tiempo. Pero también fueron centrales la dinámica creada por la experiencia colonial y las nuevas prácticas de autoridad y gobierno. Este proceso dio lugar a la formación de cargos como caciques o gobernadores, quienes desarrollaron diferentes estrategias encaminadas a legitimar sus títulos, de acuerdo a las exigencias de las leyes de Indias para ocupar una posición de representación o hacer legítima la base de su autoridad sobre una comunidad que era política y territorial. En este contexto se dieron movimientos de rebeldía como el Taqui Onqoy o el levantamiento de Túpac Amaru. Con relación al Taqui Onqoy, Steve Stern (1982) dice que el movimiento iniciado en 1564 fue la respuesta indígena a los intentos de reclutar mano de obra para las minas de Huamanga, extendiéndose posteriormente a otras regiones. Simbólicamente, expresó una alianza de las 
divinidades andinas para derrotar a los españoles (Stern 1982, 49). Así pues el Taqui Onqoy esperaba una inversión inmediata de las relaciones políticas, generando un discurso de retorno al pasado. Así, la historia no se desplaza en la línea del tiempo guiada por un hilo conductor que se desenrolla progresivamente acercándose al final. La realidad de la pacha del ahora y el aquí, sigue las categorías cósmicas que definen lo que la historia es, fue y será.

Hay un entonces un paralelismo simbólico entre el pensamiento de líderes como Toqui Onqoy en el alto Perú, Túpac Amaru en el Cuzco, Tupaj Katari en la Paz y Quintín Lame en los andes colombianos. Dicho paralelismo simbólico puede rastrearse a través de la idea de reestablecer una autonomía territorial y política de los indígenas que fuera capaz de derribar las relaciones de servidumbre instauradas por el poder imperial español (Espinoza, 2009, 60).

En este orden de ideas, debemos comprender la autoridad que ejerció Lame sobre el movimiento indígena colombiano, y como esta estuvo siempre ligada a la memoria indígena. El ejercicio discursivo de Lame implica una recreación particular de una visión política de autoridad y revelación que estuvo ligada de manera directa a su situación de terrazguero, y al hecho de no ser miembro de un resguardo, ni tener un rol de autoridad ligado por ancestros y reconocido públicamente por la comunidad. En este sentido “ (Lame) visualizó, y junto con los que le siguieron, puso en escena rituales híbridos de poder, de marcación simbólica del territorio, curación y renacimiento cultural ". (Espinoza, 2009, 60).

Así pues, la difusión del discurso de Lame como ejercicio deliberado del recuerdo, estuvo guiado por un componente educativo centrado en la creación de " escuelas indígenas", la reapropiación de símbolos culturales y espirituales ancestrales o a una nueva forma de relacionarse con los símbolos del dispositivo de control de la modernidad "Ejemplos de esto 
fueron entonar el himno nacional al inicio de la mingas adoctrinadoras indígenas e interrumpir el canto para anunciar las traiciones a las que los indígenas habían estado expuestos desde la Independencia”. (Espinoza, 2009, 63).

A una época de vida bajo un ideal ético, (período prehispánico), le sobreviene una etapa de corrupción ética (dominio occidental) que legitima la lucha indígena. En este orden de ideas, la degradación ética de los occidentales implica un desgaste en el poder del mismo y legitima una nueva edad de armonía indígena con la naturaleza. Podemos pues entender desde este punto de vista, la fuerza con la que Lame establece el antagonismo ético entre el indígena y el occidental, como la formulación de un criterio ético desde el cual comprender la historia, y que legitima el día del levantamiento indígena por la reconstrucción de su dominio sobre su territorio. En esta medida Manuel Quintín Lame, al iniciar su obra, devela la existencia del blanco, que a través de los siglos con su egoísmo soslayó la esperanza y la vida de las comunidades indígenas al interior de América Latina. Por este motivo y teniendo en cuenta la articulación discursiva en la obra de Manuel Quintín Lame es preciso señalar los momentos históricos en los cuales se manifiesta y se constituye el antagonismo. El primer momento se puede identificar con la conquista española, en este aspecto Quintín reconoce que con la llegada de Cristóbal Colón el 12 de Octubre de 1492, la libertad del indio quedo sepultada, sus riquezas fueron usurpadas y la sabiduría indígena sustentada en el conocimiento de la naturaleza, fue puesta en duda por los conocimientos occidentales de las grandes academias educativas. Esta ruptura puso en tela de juicio el conocimiento ancestral del indígena, llevándolo hacia el exilio, el desplazamiento y la humillación:

"Esa humanidad envuelta en medio del orgullo, sedienta de riquezas, de las riquezas de mis antepasados, aquellos que se encuentran hasta hoy en extensas poblaciones en 
el vientre de la tierra Guanani; con el fin de favorecer sus riquezas y favorecer sus vidas de la persecución de los que llegaron el 12 de octubre de 1492 con el supuesto nombre de conquistadores españoles" (Lame, 1971, 45)

El segundo momento se establece cuando las tierras de los indígenas comienzan a ser fragmentadas por medio de la ley. En este aspecto y después de la independencia, las tierras de los resguardos comenzaron a ser vendidas, cedidas y regaladas a través del engaño y la mala fe del blanco, el cual sacando provecho de la ignorancia del indígena, le fue arrebatando sus tierras. En este aspecto según Quintín Lame y debido al fraccionamiento del territorio, el indígena fue reducido y relegado, dejando en la tierra usurpada su identidad.

"El blanco le roba la finca al indígena, emborrachándolo; haciéndole firmar documentos de débito sin deberle; llevándolo ante los jueces para seguir la ejecución, y el juez se presta diciéndole a uno " es mejor que pague”, contradice uno " pero yo que pago si yo no debo nada" y le ordenan al indio “ nombre abogado" ( Lame, 1971, 39)

El tercer momento se da con la disputa legal y activa, realizada por la Quintinada liderada por Manuel Quintín Lame, en este aspecto la presencia del blanco, debilitó los procesos reivindicativos del movimiento y debido a esto y a través de las calumnias y las mentiras Quintín fue objeto de discusiones y acusaciones, las que determinaron su posterior encarcelamiento en la ciudad de Popayán.

En Popayán engrangrenaron las consciencias de los jueces los doctores Miguel Arroyo Díaz y el doctor Guillermo Valencia, en contra del sindicado Manuel Quintín Lame, por haber aprendido a pensar para pensar (Lame, 1971) 
El cuarto momento, será la victoria indígena de la que Lam funge como profeta e iniciador. Así pues, la restitución de la ética del indígena dominando el territorio será el inicio de un nuevo momento de un nuevo ciclo en la historia latinoamericana.

Lame señalará como el fin de la época prehispánica o mítica se anuncia con la guerra fratricida que debilita al indígena y le impide ganar la batalla contra el conquistador, elemento común a toda la memoria mítico histórica de la zona andina del continente:

"Cien años antes del 12 de Octubre el indio Güelpa en una reunión de sabios en el templo de Cacharpa, lugar donde se elevaban holocaustos al sol como dios misericordioso, después de haber cantado tres veces el himno al sol en que se suscitó una disputa; después de todo llamó la atención Cacharpa y le anunció a todo el Sanedrín en palabras lentas en el dialecto indígena que muy pronto quedarían los sabios y los soberanos en manos de Guagáz" (Lame, 1971, 23)

Según Gonzalo Catillo, Guagáz ( o Guagás) quiere decir, hombre blanco. En el contexto mitológico del relato de Lame equivaldría igualmente a "enemigo" o "demonio". (Lame, 1971, 23)

"Pasaron los tiempos y con ellos las guerras entre los soberanos indígenas quienes se disputaban Riberas, Praderas o Campos de dominio etc. y se despedazaban unos con 
otros con lanzas de madera, flechas y bodoquera envenenada, el veneno sacado de plantas vegetales." (Lame, 1971, 24)

En ese orden de ideas, se debe entender el llamado de Lame a la lucha a todos los pueblos ancestrales contra el colonialismo. Para que evidentemente ocurra un nuevo cambio de ciclo que restituya el dominio indígena sobre el territorio, dicho cambio será impulsado por la lucha por la tierra, pero esta lucha debe implicar la unidad indígena para no repetir dichas guerras fratricidas, la comprensión de la doctrina es decir el conocimiento de la naturaleza sacralizada que impulsa la lucha mediante sus enseñanzas y la retoma de la relación ancestral de espiritualidad con la naturaleza. 


\section{Conclusiones}

A lo largo del texto Pensamientos del indio que se educó en las selvas colombianas, de Manuel Quintín Lame es posible ubicar varias ideas que lo atraviesan. En primer lugar una reivindicación del autor como vocero de la causa indígena, legitimación que alcanza matices espirituales, con lo que Lame se presenta con una autoridad política y espiritual, donde se presenta a sí mismo como heredero de una tradición de mayores y líderes que ostentan una potestad basada en la sabiduría tradicional indígena, a la vez que como portador de un conocimiento liberador para la causa indígena en nuestro país. La segunda idea que recalcará Lame en su escrito es el origen de su sabiduría en la naturaleza. Partiendo de lo anterior, justificará su lucha como una batalla por la humanidad del indígena, que justifica explicitando el origen propio de su pensamiento y su oposición a la mentalidad occidental colonizadora y racional. En este sentido insistirá en que no tuvo formación intelectual o académica, y que todo su conocimiento partirá de su relación con la tierra: "No es verdad que solo los que han estudiado 15 o 20 años, son los que han aprendido a pensar y son los que han tenido vocación por que han subido del Valle al monte. Pues yo nací y me crie en el monte y del monte baje a escribir la presente obra". (Lame, 1971, 12). Dicho conocimiento, concebido pues en el monte será una revelación de la naturaleza, que aparecerá como maestra espiritual, ética e intelectual de Lame, a la vez que oficia como defensora y guardiana del indígena. Una tercera idea que atravesará el texto de Lame, será la de la propiedad ancestral de los indígenas sobre la tierra, sustentada en su relación espiritual con la naturaleza que encarna a la divinidad. Así, pues, la propiedad colectiva de las comunidades indígenas sobre sus territorios, más que sobre títulos legales, se sustenta en la autoridad espiritual que le da al indígena su relación mística con el ambiente. Huelga aclarar, que no obstante, como táctica de lucha política Lame legitimará los 
títulos legales de propiedad existentes desde la colonia, no como fuente de su dominio sobre el territorio, sino como confirmación del mismo. "Estas tierras son exclusiva propiedad que dio el Juez Omnipotente a nuestros primeros padres (...) quien hubiera dicho entonces, sin tenerlo a locura, que más tarde unos huéspedes ambiciosos habían de arrebatarnos por la fuerza todos nuestros bellísimos jardines”. (Lame, 1971, 21).

En este punto del texto iniciará Lame caracterización de las relaciones de poder que oprimen a los indígenas, para después insistir en ciertos consejos prácticos que eviten que la indígena sea robado o pisoteado, que podríamos entender como un manual táctico para evadir dichas realidades opresivas. En este punto se señalan aspectos como no creer en la amistad del blanco o el mestizo, desconfiar de regalos o halagos de los latifundistas y los comerciantes venidos de la ciudad, el entablar cualquier acción jurídica de forma autónoma sin recurrir a abogados blancos, y el evitar pertenecer o colaborar con los partidos políticos de las élites, liberal y conservador para el caso colombiano. Entonces, se detendrá en lo que podemos entender como la base epistemológica de su propuesta, una descripción de la cultura ancestral, sustentada en valores éticos, y esta cultura ancestral indígena que defiende, que provienen de una cultura que guarda memoria de los siglos de las lecciones de la naturaleza. Es decir, a partir de una relación mística y milenaria con la tierra, se ha elaborado un conocimiento profundo del universo, del que son guardianes ya actuantes las comunidades indígenas, en tanto es un conocimiento que la divinidad ha puesto en la naturaleza, y esta con paciencia de maestra ha enseñado a los indígenas. De esta manera, el conocimiento reside en la Naturaleza y es en marco de una relación espiritual del indígena con ella donde este obtiene conocimiento. De esta sabiduría revelada por la naturaleza, se derivarán consecuencias sociales y políticas, en tanto es presentada como la base ideológica con la que 
Lame espera construir la victoria indígena a partir de la resistencia contra el dispositivo de control colonialista "Por medio de mi fe, que dejo escrita en este libro, se levantará un puñado de hombres indígenas el día de mañana, y tomaran los pupitres, las tribunas, los estrados, las sesiones jurídicas...porque las inteligencias de la raza indígena superan y superarán extraordinariamente al blanco". (Lame, 1971, 35).

Una vez establecido una hermenéutica general del texto, la investigación se enrutó a interrogarse por la concepción de historia de Lame. Asumiendo como el mismo texto presenta la clave de interpretación del mismo, se visibilizó la necesidad de entender el pensamiento indígena, en este caso concreto el texto de Lame, desde la cultura indígena misma; desde el sentido de una cultura y pensamiento propios, en tanto, siguiendo a Foucault, sólo el pensamiento que pudiera recuperarse a sí mismo en la raíz de su propia historia podría fundar con seguridad lo que la verdad solitaria de los sucesos ha sido en sí misma(1968), lo que en la práctica implica efectuar una interpretación filosófica del texto de Lame como actividad en función de una comunidad histórica (comunidades indígenas Colombianas), tomando la narrativa simbólica del autor, para efectuar una labor interpretativa, que nos permita categorizar la episteme indígena sobre la que se sustenta el texto. En coherencia con lo anterior, se contextualizo el pensamiento de Lame en la zona cultural quechua, partiendo del análisis del proceso de expansión e influencia de la lengua quechua a partir de las conquistas incas en primer lugar, y de los movimientos poblacionales y lingüísticos que trajo consigo el proceso de colonización española; analizando la cultura quechua y dentro de ella la comunidad nasa. En este rastreo se ubica que el pensamiento general de Lame se encuentra atravesado epistémicamente por tres categorías generales, la concepción andina de Pacha, la religiosidad andina y la concepción nasayuwe de la metamorfosis de la vida. El 
paso siguiente es entonces delimitar la concepción de historia de Lame partiendo de estas tres categorías, enmarcándolo en los interrogantes que ha hecho la filosofía occidental de la historia, clasificados partir de Walsh( 2006) en filosofía crítica y filosofía especulativa de la historia.

Desde la filosofía crítica de la historia, vemos que la importancia que le da Lame a la Naturaleza como un todo que incluye al ser humano, de forma análoga al concepto quechua de Pacha, tendrá varías implicaciones, en tanto engloba las realidades natural y humana, no permite deslindar lo humano de lo natural o lo territorial, y por ende, no sería posible deslindar lo natural de lo histórico. Es entonces la historia un relato de la memoria del ser humano en la Naturaleza, del ser humano y su relación en y con la Pacha. En esa medida es que la historia solo es cognoscible a partir del conocimiento revelado por la Naturaleza, quien en tanto fuente de todo conocimiento asume el rol de generadora y guardiana del conocimiento histórico, que revela de forma espiritual a los indígenas para que puedan narrar, conocer y hacer vivo el recuerdo. Es pues un recuerdo sacramentalizado en tanto se proyecta en el presente gracias a la intervención espiritual de la Naturaleza, para servir de guía ante los problemas contemporáneos de las comunidades indígenas.

Por su parte, desde la filosofía especulativa de la historia, la presencia espiritual de la Naturaleza, implica a su vez, un accionar de índole mítica de la misma, es decir una estructura narrativa que mediante imágenes simbólicas como metáforas o alegorías da cuenta de la presencia divina encarnada en la Naturaleza y su conocimiento a lo largo de la historia. Esto explique no solo la pervivencia sino la centralidad de los arquetipos míticos presentes en la narración histórica de Lame. 
Es decir, la realidad trascendente de la historia o factor determinante de la misma, será, el desarrollo de la Pacha misma en tanto realidad histórica y temporal que contiene y genera la dimensión misma de lo humano, que se desarrolla siguiendo el esquema de pensamiento Nasa de La metamorfosis de la vida, a partir de la relación espiritual del indígena con la Pacha, que tiene diversos walaiyas o momentos, que van desde la creación misma de la pacha y por esta del ser humano, la organización del universo por los dioses y la vida del indígena acorde a las leyes emanadas de la misma naturaleza, fragmentadas por la colonización española y su subsecuente cambio en la realidad territorial del indígena. Es en este sentido, que el centro de la narración es el 12 de Octubre de 1492, pues a partir de él se puede proyectar la ruptura de la vida indígena sustentada en toda la dimensión simbólica de la Naturaleza, como la imperiosa necesidad de asumir los problemas contemporáneos a Lame desde la reivindicación del pensamiento propio, que siguiendo los citados casos de resistencia epistémica, se asume como elemento subversivo, lo que permite que Lame pase a ser parte de la memoria indígena como guardián y maestro el conocimiento indígena y se integre así mismo al espíritu de la pacha ene se sentido, ya sea al ser enterrado en el sitio sagrado de los Mohanes Pijaos, o ser representado en los chumbes Nasa como una walaiya misma de la relación entre Nasa y Nasa Kiwe.

Interpretando la historia como un relato, partiendo de la acepción original del texto, el punto de partida de Lame es la denuncia, denuncia de sus sufrimientos y los de su pueblo. Al describir dichos episodios en los que el indígena se configura como víctima, los sufrimientos de Lame están narrados estableciendo una analogía a los de figuras bíblicas como Jesús, Moisés y Noé de forma acorde a la concepción religiosa del autor, que ya ha sido descrita en el segundo capítulo del presente trabajo. 
Todos mis actos quieren borrarlos en forma que los Judíos pidieron al gobernador Romano que borrara o quitara el inri de la Cruz, etc., y los Césares quisieron ocultar el misterio de la Pascua, es decir, de la Resurrección del que había muerto en la Cruz. (Lame, 1971, 57).

Ahora bien, estos sufrimientos tienen un origen histórico concreto, que es la llegada de los españoles en 1492, momento de la gran fractura que dio comienzo a la historia de injusticias e iniquidades contra el hombre indígena.

A partir de allí, el recuerdo sobre las atrocidades de la conquista, pasa a ser un elemento de problematización de la historia latinoamericana, pues ante la exposición de la injusticia del colonialismo se cuestiona la validez de los derechos de los conquistadores y sus descendientes. En oposición al momento histórico del colonialismo, se resalta la grandeza y el poderío de las antiguas culturas, dioses y pueblos de América indígena. Persistentemente se niega a llamar a nuestro continente por el nombre europeo y lo sustituye por el nombre de Guananí, primera tierra americana pisada por los europeos. En este momento su discurso se proyecta hacia el futuro que verá el resurgir de los pueblos indígenas, triunfantes y autónomos. En este punto, se señala con cierta recurrencia "la ley de la compensación" la cual restituirá al pueblo indio sus tierras, su autonomía, su antiguo poderío, en detrimento del blanco usurpador.

Así nacerá mañana un concierto de indígenas de esos descendientes legítimamente de nuestra tierra Guananí, descendientes de esas tribus odiadas, perseguidas del hombre no indígena; pero

la ley de la compensación existe señores porque ella misma es la justicia vengadora. ( Lame, 1971)

Una columna formará un puñado de indígenas el día de mañana para reivindicar sus derechos, como reivindicó Dios la humanidad, es decir, la rescató de la tiranía del demonio; así rescatará 
la raza indígena sus derechos en Colombia y quedará el blanco de arrendatario del indígena... (Lame, 1971)

En este sentido, discursivamente Lame sitúa el sufrimiento de sus ancestros y hermanos indígenas así como su propia lucha dentro de un contexto común aferrándose a la memoria mientras esta titilaba en un momento de peligro, el peligro de ser borrada, anulada. Lame logró articular el pasado históricamente, en un relato articulado desde imágenes del pasado a través de la yuxtaposición de marcos temporales, la omisión de explicaciones causales y la estructuración de la narración de una forma no lineal.

Lo anterior no implica la ausencia de un sentido de causalidad, pues aunque la concatenación de hechos históricos con relaciones causales no está representadas necesariamente en la narración misma, hacen parte de la memoria oral. Así pues, la forma en la que se recuerdan y organizan los hechos dentro de un marco temporal está estructurada en torno al espacio físico y ritual y no a la temporalidad cronológica. Dicha estructuración discursiva implica una dimensión ritual de la historia que se basa en los contrastes y las contradicciones entre el pasado tal como fue experimentado y la estructura del mundo presente.

La historia aparece en Quintín Lame como "una narración simbólica que conjuga elementos míticos del pensamiento andino, sustentado en el concepto de Pacha, con el relato de hechos históricos. En esa medida es la descripción de las distintas Walaiyas (épocas del desarrollo de Nasa Kiwe según el pensamiento Nasa) orientado en una lógica narrativa que proyecta los acontecimientos del tiempo de los mayores y los ancestros ( yecteywe) sobre el momento presente del autor ( acxtey); para a partir de la misma formular un plan de vida conjunto para el pueblo Nasa que, reivindicando la autoridad espiritual de los caciques míticos permita plantear un proyecto de vida conjunto para los indígenas colombianos, 
sustentado en la reapropiación de la autonomía territorial bajo los preceptos de gobierno propio indígena. Este plan de vida, tiene una perspectiva de sustentación en la religiosidad andina, que partiendo de la visión andina de Dios como creador y organizador del mundo, y de la visión de Jesucristo como liberador de los oprimidos del mundo, plantea asumir la liberación del territorio del dominio colonialista para experimentar en esta lucha la reimposición del orden del Nasa Kiwe emanada de la divinidad, y como concreción del proyecto de la esperanza cristiana para los explotados."

La historia en el pensamiento de Lame expresa el orden y el desorden según una secuencia desde los soberanos antiguos hasta el cacique Juan Tama. Tal alternancia se verificaría, por una parte, en la disposición de elementos sociales y materiales que expresarían la unidad espiritual con el territorio y la producción cultural.

En el transcurrir del tiempo, Lame mismo es el momento en el que se desencadenan las fuerzas de inversión constituyéndose un nuevo orden. Sin embargo, teniendo en cuenta que los cambios se dan en analogía respecto del futuro y el pasado, resulta en que el propio Lame representa un momento limítrofe. El liderazgo espiritual y político de Lame se asocia entonces con un nuevo período, una inversión que anuncia "el tiempo de los indios".

El pensamiento de Lame es un proyecto intelectual de la esperanza frente al peligro. Es comprensible que desde un punto de vista filosófico este pensamiento sobre el futuro y sobre el tiempo pueda, a su modo, ayudar a una teoría escatológica.

Existe una separación entre realidad como es y como debiera ser. En otras palabras, la comunicación espiritual con la Pacha se entiende como una palabra de promesa en la cual "la revelación" y "la enseñanza" de esta es preanuncio del futuro. 
El llamado de Lame a la acción, es decir, su enseñanza de acuerdo a los preceptos de la sabiduría de la Pacha, procede como una autorrevelación de la Naturaleza de forma indirecta, a través de las gestas históricas de los indígenas por le territorio.

La revelación no está compuesta por hechos desnudos, sino por acontecimientos que reciben significado solo en relación con la episteme andina. Los acontecimientos de la historia hablan el lenguaje de la Naturaleza, pero este lenguaje, solo se puede oír en contexto y en el ámbito de la tradición ancestral, la episteme andina y la espera por una restitución del orden cósmico en medio de la cual transcurre la historia.

La historia es entonces una narrativa simbólica de la memoria, entendiendo por esta última, no la tendencia a ver el pasado bajo la óptica endulzada de la idealización, sino como una manera de disociarse de los hechos como son, en nombre de contenidos subversivos y peligrosos para el statuo quo. En el marco de la episteme andina, Lame renueva la memoria ancestral nasa, y siguiendo los preceptos de la pacha hace memoria de la dimensión simbólica del territorio que posibilita una organización social acorde a los usos indígenas. En ese sentido, Lame encarna en el más alto grado esa memoria simbólica y liberadora.

Lo anterior, implica un esfuerzo por expresar la sabiduría ancestral en relación con la época moderna como figura simbólica que detone la acción política. Es entonces un simbolismo memorial y narrativo de la memoria, cuyo dato central está constituido por el recuerdo narrativo de la relación espiritual con el territorio.

La narración mantiene presentes a las generaciones pasadas evitando olvidar o desechar los dolores del pasado, de los ancestros que sufrieron la conquista y las violencias del colonialismo, trayéndolos a colación en la reivindicación del pensamiento ancestral y en la lucha presente por 
la liberación indígena; trayendo en el bienestar de los nietos el remedio al sufrimiento de los abuelos, víctimas del ayer, en tanto son miembros partícipes de la comunidad espiritual indígena sustentada en la relación con la naturaleza

En ese orden de ideas, el discurso de Lame alrededor de la historia se establece como una historia de los vencidos, en tanto se condensó la historia de sus antepasados, a través de una serie de imágenes narrativas y simbólicas que denuncian la conquista e iluminan el presente de opresión de los indígenas. En el texto el año de 1492 se señala como la fecha icónica de la era de dominación para los indígenas, mediante el deseo español de "comer sin trabajar" y su práctica colonizadora mediante la expropiación de las riquezas materiales y espirituales de los nativos. En este orden de ideas Lame denuncia el lado oscuro de la civilización occidental: el despojo territorial, el abuso, la injusticia y el sufrimiento.

La rememoración de la historia indígena sobre la cual está construido el texto de Lame nutrió la memoria moral y la conciencia histórica de los indígenas colombianos, en una narrativa que combina la necesidad de restauración del orden cósmico de la pacha, con la denuncia de las relaciones de poder que alteraron el mismo y que fueron impuestas de manera violenta por los españoles. Así pues, el presente se caracteriza porque reúne los procesos del pasado y el futuro. Desde atrás, el futuro augura la venida de un nuevo liderazgo emanado del conocimiento sagrado de la Pacha que de manera pendular reorganizará las relaciones prevalecientes retornando a un orden donde prevalezcan las categorías epistémicas de los oprimidos sobre las de los opresores. En este sentido, el cambio que se dará con relación al presente, representa la ausencia de sujeción y explotación étnica. Así pues, la difusión del discurso de Lame como ejercicio deliberado del recuerdo, estuvo guiado por un componente educativo centrado en la creación de " escuelas indígenas", la reapropiación de símbolos culturales y espirituales ancestrales o a una nueva 
forma de relacionarse con los símbolos del dispositivo de control de la modernidad. En este orden de ideas, la degradación ética de los occidentales implica un desgaste en el poder del mismo y legitima una nueva edad de armonía indígena con la naturaleza. Podemos pues entender desde este punto de vista, la fuerza con la que Lame establece el antagonismo ético entre el indígena y el occidental, como la formulación de un criterio ético desde el cual comprender la historia, y que legitima el día del levantamiento indígena por la reconstrucción de su dominio sobre su territorio. En esta medida Manuel Quintín Lame, al iniciar su obra, devela la existencia del blanco, que a través de los siglos con su egoísmo soslayó la esperanza y la vida de las comunidades indígenas al interior de América Latina. Por este motivo y teniendo en cuenta la articulación discursiva en la obra de Manuel Quintín Lame es preciso señalar los momentos históricos en los cuales se manifiesta y se constituye el antagonismo. El primer momento se puede identificar con la conquista española, en este aspecto Quintín reconoce que con la llegada de Cristóbal Colón el 12 de Octubre de 1492, la libertad del indio quedo sepultada, sus riquezas fueron usurpadas y la sabiduría indígena sustentada en el conocimiento de la naturaleza, fue puesta en duda por los conocimientos occidentales de las grandes academias educativas. El segundo momento se establece cuando las tierras de los indígenas comienzan a ser fragmentadas por medio de la ley. En este aspecto y después de la independencia, las tierras de los resguardos comenzaron a ser vendidas, cedidas y regaladas a través del engaño y la mala fe del blanco, el cual sacando provecho de la ignorancia del indígena, le fue arrebatando sus tierras. En este aspecto según Quintín Lame y debido al fraccionamiento del territorio, el indígena fue reducido y relegado, dejando en la tierra usurpada su identidad. El tercer momento se da con la disputa legal y activa, realizada por la Quintinada liderada por Manuel Quintín Lame, en este aspecto la presencia del blanco, debilitó los procesos reivindicativos del movimiento y debido a 
esto y a través de las calumnias y las mentiras Quintín fue objeto de discusiones y acusaciones, las que determinaron su posterior encarcelamiento en la ciudad de Popayán. El cuarto momento, será la victoria indígena de la que Lame funge como profeta e iniciador. Así pues, la restitución de la ética del indígena dominando el territorio será el inicio de un nuevo momento de un nuevo ciclo en la historia latinoamericana. En ese orden de ideas, se debe entender el llamado de Lame a la lucha a todos los pueblos ancestrales contra el colonialismo. Para que evidentemente ocurra un nuevo cambio de ciclo que restituya el dominio indígena sobre el territorio, dicho cambio será impulsado por la lucha por la tierra, pero esta lucha debe implicar la unidad indígena para no repetir dichas guerras fratricidas, la comprensión de la doctrina es decir el conocimiento de la naturaleza sacralizada que impulsa la lucha mediante sus enseñanzas y la retoma de la relación ancestral de espiritualidad con la naturaleza. 


\section{Anexos \\ Anexo 1 Glosario de términos en lengua indígena}

\section{Lengua Quechua}

Alespaquexe: Mes lunar.

Andesuyo: Parte nororiental del Cuzco.

Anti: Raíz quechua con la que se denominaba la cordillera andina, sus pobladores y su territorio.

Antisuyo: Parte oriental de los andes desde Quito hasta las Charcas (Bolivia)

Auro: Día.

Curaca: Líder espiritual y político de nivel local.

Chinchaisuyo: Litoral pacífico de Perú, Ecuador y el sur de Colombia.

Hamawt'as : Sabios incas que en el período prehispánico cumplían funciones didácticas, investigativas y ejercían como autoridades intelectuales.

Llaky pacha: Época del sufrimiento.

Mari: Año.

Muchuy Pacha: Época de escasez o hambruna.

Minga: Derivado del vocablo quechua mink'a que significa trabajo colectivo hecho en favor de la comunidad. En el contexto del movimiento indígena colombiano se utiliza también para 
denominar las jornadas de protesta y movilización convocadas por organizaciones como el CRIC.

Pacha: Concepción espiritual de la naturaleza y el tiempo como una unidad en la que se sustenta la existencia. Se puede entender como todo aquello en lo que se encuentra el hombre y lo que está en su entorno, sobre él y bajo él, desde un punto de vista territorial, temporal, espiritual y existencial. Cotidianamente se utiliza para denominar la naturaleza o el tiempo.

Pachamama: Madre Naturaleza. Representación femenina de la Pacha, en tanto origen y manifestación de la existencia, madre de la vida, el territorio y el tiempo.

Pachacamaq: Creador y organizador de la naturaleza, del mundo, del espacio y del tiempo

Paqarina: Representación con características femeninas del vientre de la tierra, es decir del lugar de origen sagrado de la vida.

Quipo: Sistema escritural basado en nudos, con el que se hacía recuento documental de asuntos históricos y contables.

Runa: Ser humano. Autores como Mejía Huamán (2011) o Esttermann (1998) lo usan como término genérico para referirse al hombre andino.

Runasimi: Literalmente lengua de hombres andinos Nombre dado a la lengua quechua.

Tahuantinsuyo: Literalmente las cuatro partes de este mundo. Nombre dado hacia el siglo XIV al territorio gobernado por los señores Incas.

T’inkay: Acción de regar chicha. Mario Mejía Huamán (2011) señala que tiene implicaciones rituales como tributo a la Pachamama. 
Ticeviracoha: Nombre con el que el Inca Garcilaso se refiere a Viracocha.

Viracocha: Dios supremo de los pueblos andinos. Se identifica con Pachacuti.

Wiñay Pacha: Tiempo de la eternidad.

\section{Lengua Nasayuwe}

$A$ 'te: Luna

Acuachimuyú: Imperativo para caminar. Camine.

Auchigá: buenos días.

Cuscachí: Adiós o hasta mañana.

Chitemas: Nombre con el que Quintín Lame se refiere a los indígenas paeces o nasas.

Chumbe: Tejido.

Eekthe wala: El gran sabio del espacio. Dios creador y organizador del mundo para el pueblo Nasa.

Fxiw: Semilla

Guachumiyú: Imperativo para correr. Corra.

Muschka: Divinidad solar nombrada por Quintín Lame.

Nasa: Gente. Término genérico con el que se autodenomina el pueblo indígena Páez.

Nasa Kiwe: Territorio nasa. La expresión se utiliza también para designar a la Naturaleza de forma análoga a la expresión quechua de Pacha. 
Ollo: Deidad femenina nombrada por Lame, que podemos identificar con la revelación del conocimiento de la Naturaleza.

Peex Kpux: La metamorfosis de la vida.

Sat: Cacique.

Sinviora: Divinidad que nombra Lame, quien entregó códigos de religiosidad y comportamiento a los indígenas.

Tay: Sol

Txiwe mama o txiwe nxhi: Madre tierra. Concepto análogo al de Pacha mama.

Txiwe uus: Corazón de la tierra, representación del origen de la vida, análogo al concepto de Paqarina.

Uma: Agua

Yat: Casa.

Yat Wala: Territorio ancestral

\section{Otras Lenguas}

Cacique: Derivado del término cakchiqueles de la lengua Quiché, con el que se denominaban los jefes políticos cuya autoridad tenía un componente espiritual. A partir de la adopción el término en lengua castellana, se utiliza como genérico para designar a los jefes indígenas de todo el continente. 
Guananí: Derivado de Guhananí, nombre en lengua de los indios tahíno de la Isla de San Salvador (Actual territorio de las Bahamas). Quintín Lame lo utiliza como término genérico para referirse al continente americano.

Mohán: Vocablo de la antigua lengua Pijao. Corresponde a antiguos sacerdotes que tras la conquista han pasado a ser espíritus guardines de la naturaleza y el conocimiento ancestral. 


\section{Referencias bibliográficas}

\section{Fuente Principal}

Lame, M. Q. (1971) En defensa de mi raza. Los pensamientos del indio que se educó en las selvas

colombianas. Bogotá: La Rosca de Investigación y Acción Social.

\section{Bibliografía Consultada.}

Abbagano, N ( 1994) Historia de la filosofía. Barcelona: hora

Ardila Calderón, G.I. (1991) Etnia y Conflicto en el Sur del Tolima. Ibagué: Gobernación del

Tolima

Aristóteles.( 1999) Poética. Madrid : Gredos

Bacon, F. (1988) El avance del saber. Madrid: 1988.

Bonilla, V. (1979) ¿Qué política buscan los indígenas? En Indianidad y descolonización en

América Latina. México: Editorial Nueva Imagen.

Burga y Flórez (1982). La utopía andina. Cuzco: Instituto pastoral andio.

Castrillón, A. (1973) El indio Quintín Lame. Bogotá: Tercer Mundo Editores.

Castillo, G. (1987) Liberation Theology from below, the life and thought of Manuel Quintin Lame.

New York: Orbis Book. 
Cieza de León. (2005) El señorio de los incas. Lima: Instituto de estudos peruanos.

CRIC (1989). El movimiento Indígena. Bogotá: Cinep

CRIT (2000)_Fundamentos y práctica de la medicina tradicional Pijao. Ibagué: Ministerio de Cultura.

Duque Gómez, L. (1967) Tribus Indígenas y sitios arqueológicos. Bogotá: Academia Colombiana de Historia.

Dussel, E. (1966). Hipótesis para el Estudio de Latinoamérica en la historia universal.

Tucuman: Universidad del sudoeste.

Dussel, E. (1992) 1492: el encubrimiento del otro: hacia el origen del mito de la modernidad. Bogotá: Ediciones Antropos.

Empédocles. Acerca de la Naturaleza. Recuperado en www.Cervantesvrtua.com

Espinoza, M. (2009) La civilización montés: La visión india y el trasegar de Manuel Quintín Lame en Colombia. Bogotá: Universidad de los Andes.

Espinoza, M. (2003) El indio lobo. Manuel Quintín Lame en la Colombia moderna. Revista colombiana de antropología. Vol. 39

Estermann. (2000) Filosofía Andina.

Fajardo, D. (1981) Las luchas indígenas por la tierra en el Tolima durante el siglo XX, en. En 
Friede, N.S de Friedman y D. Fajardo (Ed.), Indigenismo y aniquilamiento de indígenas en Colombia. (PP. 115- 126). Bogotá: CIEC.

Fajardo, L. A. (1999) Manuel Quintín Lame y los guerreros de Juan Tama. Multiculturalismo, magia y resistencia. Bogotá: Nossa y Jara editores/ Colectivo alas de xue.

Ferrater. Diccionario de Filosofía.

Findji, M.T y Rojas J.M. (1985) Territorio, Economía y sociedad Páez. Cali: Universidad del Valle.

Foucault. ( 1987)Arqueología del saber. México: Siglo XXI.

Foucault. (1998) Genealogía del Racismo. Buenos Aires: Caronte Ensayos.

Gadamer, H. G. (1984). Verdad y método: fundamentos de una hermenéutica filosófica, Salamanca: Sígueme.

Gadamer, H.G. Mito y razón.

Garcilaso de la Vega, Inca. Comentarios de los Incas. Lima: Universidad mayor de San Marcos.

Gilhodes, P. (1989) La cuestión agraria en Colombia (1900-1946), en Tirado Mejía A. (ed.) Nueva Historia de Colombia, (pp. 307- 337). Planeta, Bogotá.

Heming. La conquista de los incas.

Hegel G.W.F. (2011) Filosofía de la historia. México: FCE

Humboldt (1982) Del Orinoco al Amazonas. Barcelona: Verdaguer. 
Juvenal Pacheco (1994). La filosofía inca y su proyección al futuro. Cuzco: Universidad San Antonio Abad.

Kant, I. (1994) ¿Qué es la ilustración?, en Filosofía de la historia, México: FCE.

Kant, I. (1994) Ideas para una historia universal en clave cosmopolita, en Filosofía de la Historia. México: FCE.

Kusch R (1962) América Profunda. Buenos aires: Editorial Hachette.

López (1985) Putumayo en el tiempo y el espacio. Mocoa: Diocesis de Mocoa - Sibundoy

López del Rey. (1992) Un líder y su causa: Quintín Lame: Popayán: Academia de historia del Cauca.

Luna, J. L. (2012) Lógicas de la filosofía de la historia. Bogotá: Universidad de San Buenaventura.

Mazzi Huaycucho, V. (1994) Presentación de Juan Yunpa. Lima:Kollana editores

Medina, M. (1986) La resistencia campesina en el sur del Tolima. En G. Sánchez y R. Peñaranda (ed.) Pasado y presente de la violencia en Colombia. (PP. 223- 265). Bogotá: Cerec.

Mejia Huaman, M. (2005) Hacia una filosofía andina.

Mejía Huaman, M. (2011) Teqse. Lima: Universidad mayor de san marcos

Museo Nacional de Colombia (2006). Historia de la fotografía en Colombia. Bogotá: Planeta.

Pacheco , J.M (1975), Historia eclesiástica en Historia extensa de Colombia. Bogotá: Academia

Colombiana de Historia. 
Pacheco J.M (1959) Los jesuitas en Colombia. Bogotá: Editorial San Juan Eudes.

Piaget. ( 1975) El estructuralismo. México:FCE

Platón. Diálogos .( 1975) México: Porrua

Piedrahíta (1973) Historia eclesiástica de Antioquia. Medellín: Editorial Granamericanca.

Pease (1973) El mito del Inkarrí y la visión de los vencidos. Lima: Biblioteca de Antropología.

Polibio. (1990). Historias. Madrid: Gredos.

Poma de Ayala (1987) El primer Nueva crónica y Buen gobierno. Mexico:Editorial Siglo XXI.

Pua F. (2011) Filosofías amerindias: búsqueda de lo propio en América Latina, Bogotá:

Universidad de San Buenaventura.

Randall (1987). La lengua sagrada, el juego de palabras en la cosmología andina. Cuzco:

Instituto pastoral andino.

Rappaport J.( 1998) The politics of memory: Native historical interpretation in the colombian

andes. Durham: Duke University Press.

Rappaport, J.(2004) Manuel Quintín Lame Hoy. En Lame M. Q. Los pensamientos del indio que se educó dentro de las selvas colombianas, (pp 55-93). Popayán: Universidad del Cauca.

Rappaport, J. y Ramos, A. (2005) Una historia colaborativa: retos para el diálogo académico. 
Historia crítica 29, $39-62$.

Rocha Vivas (ed.) (2010)Antología de poesía indígena. Bogotá: IDCT.

Romero, F. ( 2006), Manuel Quintín Lame Chantré: el indígena ilustrado, el pensador indigenista. Pereira: CRIC.

Rostorowsky. ( 1976) Reflexiones sobre la reciprocidad andina. Lima: Museo Naconal.

Rostorowsky (1988) Estructuras andinas del poder. Lima: 1988.

San Agustín (2007). La ciudad de Dios. Madrid: Tecnos.

Santa Biblia (2005) Recuperada en: Bibles.og. uk

Santa Gertrudis ( 1970)Maravillas de la Naturaleza. Bogotá: Kelly.

Sanchez F. (1996) Lectura política de Manuel Quintín Lame Chantre. Ibagué: Universidad del Tolima.

Sanchez Parga (1988) Motrices de la utopía andina: Acuerdos y disensiones. Quito: Centro Andino de acción popular.

Sevilla, E (1976). Lame y el Cauca Indígena, en N.S. de Friedmann (ed.) Tierra, tradición y poder en Colombia. Bogotá: Instituto Colombiano de Cultura.

Simón, Fray Pedro (1982) Noticias historiales de la conquista de Tierra Firme en las Indias 
Occidentales. Bogotá: Banco Popular.

Spengler, (1966)La decadencia de occidente

Stern (1982) El taki onqy y la sociedad andina. Cuzco:Insttutopastral andino.

Tello, P.( 1982) Vida y lucha de Quintín Lame. Bogotá: Universidad de los Andes.

Tello, P. (1982) Aspectos históricos del resguardo indígena y su defensa a fines del siglo XIX e inicios del XX. Revista de Antropología 2, 143 - 160.

Tello, P. (1987)Lame y el sur del Tolima, Ponencia presentada en el VI Congreso Nacional de Historia, Universidad del Tolima.

Theodiasis, F. (2000) Quntín Lame, ¿Brújula del pensamiento de resistencia autóctona? En M. Jaramillo (ed.) Literatura y cultura. Narrativa colombiana del siglo XX. Bogotá: Ministerio de Cultura.

Triana, Antorveza, A. (1993). Los resguardos indígenas del sur del Tolima, En F. Correa (ed.) Colombia Amerindia. (pp. 99-140.) Bogotá: Instituto Colombiano de Antropología.

Triana, Atorvenza (1973). Las lenguas vernáculas ante la ley y la práctica en Colombia. En Revista de la Acadmeia Colombiana de Historia Eclesiástica. Medellín

Triana, Atorvenza (1987) Las lenguas indígenas en la historia social del Nuevo Reino de Granada. Bogotá: Instituto Caro y Cuervo. 
Vasco, L.G. (1997) Quintín Lame y su pensamiento de liberación indígena., Vita- Cora I, 2.

Vasco (2007) Quintín Lame: Resistencia y liberación. Tábula Rasa 9. 371 . 383

Vega, R ( 2002) Gente muy rebelde: protesta popular y modernización capitalista en Colombia (1900 - 1929). Bogotá: Pensamiento crítico.

Velandia C. y Buitrago, J. ( 1994) Etnia y Conflicto en el Sur del Tolima, 1950 - 1980.

Museológicas, Revista del Museo Antropológico de la Universidad del Tolima; Vol. II, $N^{\circ}$ $2 / 3,5-80$.

Velasco Ceballos (1945) La alfabetización en la Nueva España. México: Secretaría de Educación Pública.

Walsh. W.( 2006) Introducción a la filosofía de la historia. México: Siglo XXI Editores.

Yule y Vitonas (2012) La metamorfosis de la vida. Toribio : Cabildo etnoeducativo proyecto Nasa.

Zabala (1985) Aportaciones históricas. México: Editorial Nueva Imagen.

Zamora (1980) Historia de la provincia de San Antonio del Nuevo Reino de Granada. Bogotá: Editorial Kelly.

Zuidema (1967) El juego de los ayllus y el amaru. Paris: Journal de la societé des 
americanistes..

Zuidema (1977) Mito e historia en el antgiuo Perú . Cuzco: Insttutopastoral andino. 